\title{
LATE HOLOCENE EVOLUTION OF CURRITUCK SOUND, NORTH CAROLINA, USA: ENVIRONMENTAL CHANGE DRIVEN BY SEA-LEVEL RISE, STORMS AND BARRIER ISLAND MORPHOLOGY
}

by

Kelli Moran

December, 2012

Directors of Thesis: David Mallinson and Stephen Culver Major Department: Geological Sciences

Coastal evolution is an increasingly important area of study, especially with the projected rise in sea level, increase in storm intensity, and population increases along the nation's coasts. In order to predict how the coastal environment will respond to these changes in the future, we need to first understand the evolution of coastal systems in the past. Here I address the late Holocene evolution of Currituck Sound, North Carolina, by examining time periods with different barrier island and inlet configurations interpreted from core data.

Chirp seismic data and 13 vibracores have been used to interpret the Holocene development of this region. Four depositional units have been defined, based on lithofacies, biofacies, geophysical, and geochronologic data. The lowermost depositional unit (Unit I) is represented by quartz sand, barren of foraminifera, and is Pleistocene in age based on an OSL age estimate of $33.7 \mathrm{ka}$. Unit II consists of slightly muddy sand that fines upward to slightly sandy mud; it is barren of foraminifera, contains rooted horizons in several cores, and is interpreted as a fresh water swamp forest deposit (radiocarbon dating provide age estimates of ca. 4000 to 2800 cal y BP). Unit III is characterized by slightly sandy mud to mud containing a calcareous foraminiferal assemblage and oyster bioherms; these characteristics indicate a backbarrier estuarine environment with high salinity (ca. 25 to 35) due to open inlets in the barrier islands to the east. Radiocarbon age estimates for Unit IV range from ca. 1700 to $500 \mathrm{cal}$ y BP. 
The topmost unit (Unit IV) is composed of sediment with variable composition, ranging from clean quartz sand to mud, and contains foraminiferal assemblages that are generally mixed calcareous/agglutinated at the base overlain by entirely agglutinated assemblages. This unit represents the modern (post- ca. 1827), mid- to low salinity (less than 10), back-barrier lagoon with no inlets open in the barrier island.

Sediment and microfossil-based paleoenvironmental and geomorphic reconstructions, including variable numbers of inlets, have been used as input into the Delft3D hydrodynamic model to understand inlet related changes to tides and currents within the Sound. This modeling indicates that impacts of inlets are very localized and only inlets in the direct vicinity of Currituck Sound (i.e., between historic Caffey's Inlet and Kill Devil Hills) have a significant impact on the water levels and currents in the study area. 

LATE HOLOCENE EVOLUTION OF CURRITUCK SOUND, NORTH CAROLINA, USA: ENVIRONMENTAL CHANGE DRIVEN BY SEA-LEVEL RISE, STORMS AND BARRIER ISLAND MORPHOLOGY

\author{
A Thesis \\ Presented To the Faculty of the Department of Geological Sciences \\ East Carolina University
}

In Partial Fulfillment of the Requirements for the Degree of

Masters in Geology

by

Kelli Moran

December, 2012 
(C) Kelli Moran, 2012 
LATE HOLOCENE EVOLUTION OF CURRITUCK SOUND, NORTH CAROLINA, USA: ENVIRONMENTAL CHANGE DRIVEN BY SEA-LEVEL RISE, STORMS AND BARRIER ISLAND MORPHOLOGY

by

Kelli Moran

APPROVED BY:

CO-DIRECTOR OF

DISSERTATION/THESIS:

David Mallinson, PhD

CO-DIRECTOR OF

DISSERTATION/THESIS:

Stephen Culver, $\mathrm{PhD}$

COMMITTEE MEMBER:

Eduardo Leorri, $\mathrm{PhD}$

COMMITTEE MEMBER:

Ryan Mulligan, PhD

CHAIR OF THE DEPARTMENT

OF GEOLOGICAL SCIENCES:

Stephen Culver, $\mathrm{PhD}$

DEAN OF THE

GRADUATE SCHOOL:

Paul J. Gemperline, PhD 


\section{ACKNOWLEDGEMENTS}

I would like to thank my family and friends for being supportive throughout this process, my thesis committee for their guidance, and everyone who was willing to go out into the field with me. I would also like to thank the people who made this project possible, the NSF grant OCE-1130843 that funded the research, Jim Watson and John Woods, without them there would be no data to study and Andrew Dietsche who was the scientific diver while vibracoring. 


\section{TABLE OF CONTENTS}

ACKNOWLEDGEMENTS ................................................................................. vii

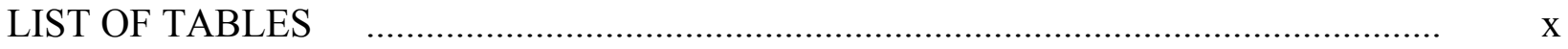

LIST OF FIGURES _............................................................................................ ix

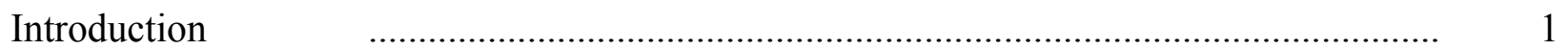

Previous Work $\quad$ _.................................................................................

Hydrodynamic Modeling .................................................................................... 8

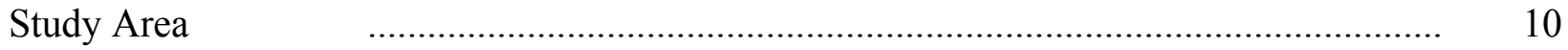

Methods

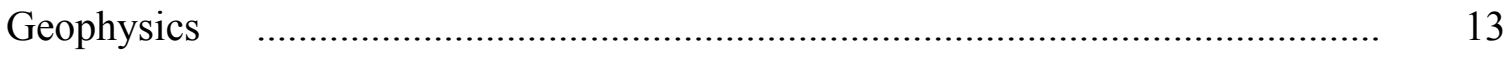

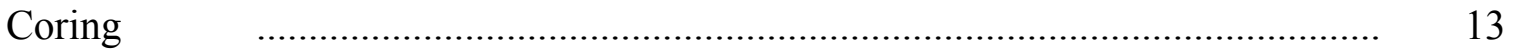

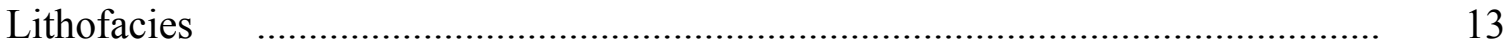

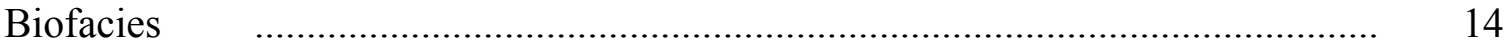

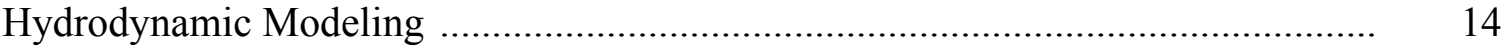

Age Analysis . ........................................................................................... 20

Results

Age Analysis .............................................................................................. 20

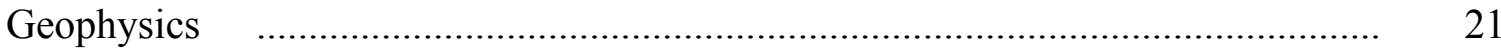

Lithofacies and Biofacies ............................................................................ 26

Hydrodynamic Modeling …………………………….................................... 34

Discussion

$\sim 5000$ - 3000 cal y BP .............................................................................. 38

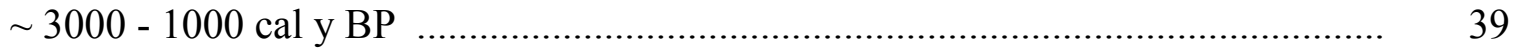

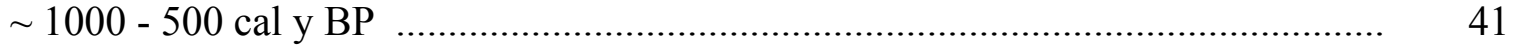

$<500$ (Modern Scenario) ...................................................................................

1590 A.D. (White - deBry Map) ……………………………………………..... 46 
Comparison to Other Studies ....................................................................................... 50

Summary

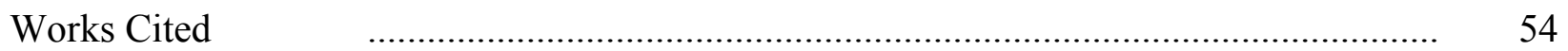

APPENDIX 1: Foraminifera species reference list …………………………………........ 63

APPENDIX 2: Foraminifera plates ……………………………………………….... 64

APPENDIX 3: Vibracore locations ........................................................................... 68

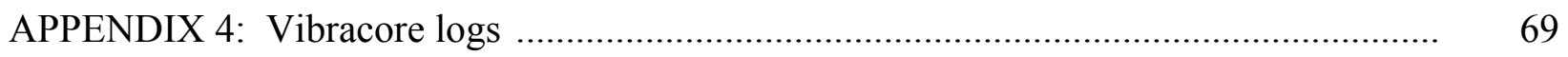

APPENDIX 5: Grain-size data ……………………….......................................... 82

APPENDIX 5: Percent mud, sand coarse sand/gravel form foraminifera samples ............. 83 


\section{LIST OF TABLES}

1. Radiocarbon age estimates .................................................................................. 19

2. Optically Stimulated luminescence age estimates …….............................................. 19

3. Seismic reflections and interpretations ……………............................................. 21

4. Summary characteristics of lithofacies recorded in thirteen vibracores ..................... 25

5. Mean percentage of foraminiferal species in three salinity-related estuarine assemblages. The three most common species in each assemblage are in bold text ........................ 26

6. Foraminiferal census data for surface (SS) and vibracore (VC) samples from Currituck Sound, NC. Surface samples were taken at same location as similarly numbered

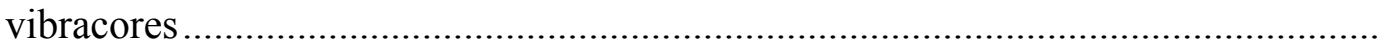

7. Table of tidal amplitude and current speed measured at each vibracore location for each

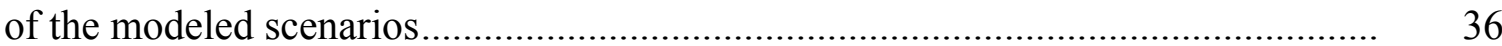




\section{LIST OF FIGURES}

1. Map showing all known historical inlets and their opening/closing dates in northeastern North Carolina. Top left is the outline of the continental United States and top right shows eastern North Carolina with important geographic areas labeled. The dashed box indicates the location of the study area in southern Currituck Sound and the dashed circle in southern Croatan Sound is the location of the paleo-Roanoke Marshes that extended

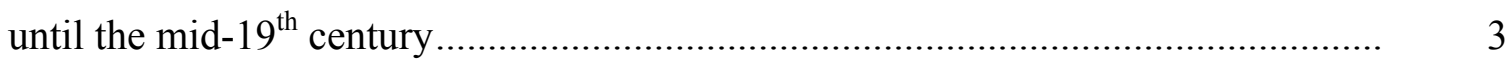

2. Map showing Chirp survey lines in southern Currituck Sound. The bold lines are seismic sections presented in Figures 4, 5 and 6. The circles are locations of vibracores (VC) 14

3. The extent and shape of the geomorphic grid overlain on a map of Currituck and Albemarle Sounds. The grid has a resolution of $100 \mathrm{~m}$

4. Interpretation of west to east seismic transects. Locations of lines can be seen in Figure 2. A) displays vibracores VC5 and VC6. B) displays vibracores VC9 and VC11. Both transects show the Pleistocene $\mathrm{P} 1$ reflection being truncated by the Pleistocene $\mathrm{P} 2$ ravinement. $\mathrm{H} 0$, a regionally continuous Holocene reflection, is the bay ravinement surface. $\mathrm{H}_{\mathrm{SF}}$ is a Holocene reflection confined to the eastern edge of Currituck Sound. It correlates to a tidally ravined sand flat or flood tide delta. $\mathrm{H} 0_{\mathrm{MRS}}$ is a reflection, also confined to the eastern edge of the Sound that correlates to the marine ravinement surface and the westward extent of the shoreline. H1, also a regionally continuous Holocene reflection, correlates to the transition between high (Unit III) and low (Unit IV) brackish environments.

5. Interpretation of chirp seismic line CUR2010-5 with core CUR11 VC12 overlain. $\mathrm{H}_{\mathrm{SF}}$ is a Holocene reflection confined to the eastern edge of Currituck Sound. It correlates to a 
tidally ravined sand flat or flood tide delta. A large oyster bioherm is in the bottom of a channel, created by $\mathrm{H}_{\mathrm{SF}}$, with infilling clinoforms on both sides. $\mathrm{H} 1$ is a regionally continuous Holocene reflection that correlates to the transition between high (Unit III) and low (Unit IV) brackish environments that occurs predominantly in the center of the Sound and corresponds to a shell layer in vibracores. Line location is shown on Figure 2

6. Interpretation of seismic line CUR2012-15 with core CUR11 VC6 overlain. P3 is a Pleistocene reflection that correlates to channelization. P2 is a ravinement surface that truncates P1 (Figure 4). H0, a regionally continuous Holocene reflection, is the bay ravinement surface. $\mathrm{H} 1$, also a regionally continuous Holocene reflection, correlates to the transition between high (Unit III) and low (Unit IV) brackish environments. Line location is shown on Figure 2

7. Seven cores forming a generally north-south transect in Currituck Sound (see Figure 8A for location). The red lines indicate the location of radiocarbon age estimates in calibrated years before present. The blue lines indicate the location of optically stimulated luminescence age estimates. The dashed lines, delineating several depositional units, indicate correlations based on lithology, biofacies and ages estimates. $\mathrm{H} 1$ and $\mathrm{H} 0$ are defined by the geophysical data. H0 is the Holocene/Pleistocene contact. H1 is the transition from high (Unit III) to low (Unit IV) brackish environments.

8. Figures $8 \mathrm{~A}$ and $8 \mathrm{~B}$ show three east west transects of cores in Currituck Sound. The red lines indicate the location of radiocarbon age estimates in calibrated in years before present. The blue lines indicate optically stimulated luminescence age estimates. The dashed lines, delineating several depositional units, indicate correlations based on 
lithology, biofacies, and age. $\mathrm{H} 1$ and $\mathrm{H} 0$ are defined by the geophysical data. $\mathrm{H} 0$ is the Holocene/Pleistocene contact. H1 is the transition from high (Unit III) to low (Unit IV) brackish environments. The transects show differences in lithology between the northern and southern ends of the Sound as well as a difference from east to west throughout the Sound

9. The evolution of Currituck Sound (interpreted from biofacies, lithofacies, and geochronologic data) for four time slices. The gray shaded land indicates the modern barrier island and mainland. A) 5000 - 3000 cal y BP: an inlet occurs just south of the modern Kitty Hawk beach ridges (Culver et al. 2008). A second inlet was possibly located adjacent to VC8. The Roanoke Marshes were present at this time, separating the Albemarle Sound from Pamlico Sound. B) 3000 - 1000 cal y BP: several inlets were open between Caffey's Inlet and the Kitty Hawk beach ridges. Due to the number and location of the inlets the marine influence was highest at this time and most likely contributed to the extensive oyster bioherm building episodes of Unit III (Figures 5, 7 and 8). C) 1000 - 500 cal y BP: only one inlet was open at the northern end of the study area and had an impact on the salinity of the Sound until it closed in 1828 (Stick, 1958; Fisher, 1962) creating the transition from Unit III to Unit IV (Figures 7 and 8). D) $<500$ cal y BP (the modern scenario): There are no inlets and the salinity changes from mid- to low salinity over time (Unit IV) (Figure 7 and 8)

10. $~ 5000-3000$ cal y BP Delft3D model run with an inlet at the mouth of Albemarle Sound as indicated by Culver et al. (2008) and Figure 9A. Location of vibracores indicated in southern Currituck Sound by dots. A) High tide in the ocean $(0.5 \mathrm{~m})$ and its effects on the estuarine system. A maximum of $0.25 \mathrm{~m}$ water level change is felt within 
Albemarle Sound and Currituck Sound remains largely unaffected. B) Low tide in the ocean $(-0.5 \mathrm{~m})$ and its effects on the estuarine system. Currituck Sound experiences a lag and exhibits slightly elevated water levels $(0.13 \mathrm{~m})$ at this time. C) Water current magnitude, with a maximum velocity of $1 \mathrm{~m} / \mathrm{s}$ directly in the inlet mouth and velocities up to $0.6 \mathrm{~m} / \mathrm{s}$ in Albemarle Sound. Currituck Sound experiences current velocities up to $0.6 \mathrm{~m} / \mathrm{s}$ in the southern end, near the location of vibracores $\mathrm{VC} 9-\mathrm{VC} 13 \ldots \ldots \ldots \ldots . . .39$

11. $3000-1000 \mathrm{cal}$ y BP Delft3D model run with Caffey's Inlet complex open as indicated by Figure 9B; Roanoke Inlet is also open. A) High tide in the ocean $(0.5 \mathrm{~m})$ and its effects on the estuarine system. A maximum of $0.45 \mathrm{~m}$ water level change is felt within Currituck Sound. B) Low tide in the ocean $(-0.5 \mathrm{~m})$ and its effects on the estuarine system. Southern Currituck Sound exhibits a $-0.45 \mathrm{~m}$ water level at this time and a maximum tidal range of about $1 \mathrm{~m}$. C) Water current magnitude, with a maximum velocity of $1 \mathrm{~m} / \mathrm{s}$ directly in the inlet mouths and velocities from $0.3 \mathrm{~m} / \mathrm{s}$ to $0.7 \mathrm{~m} / \mathrm{s}$ within Currituck Sound in localized areas surrounding inlets

12. $1000-500$ cal y BP Delft3D model run with Caffey's Roanoke and paleoGunt/Oregon inlets open as indicated by Figure 9C. A) High tide in the ocean $(0.5 \mathrm{~m})$ and its effects on the estuarine system. A maximum of $0.5 \mathrm{~m}$ of water level change is felt in the immediate area of the inlets while a $0.25 \mathrm{~m}$ water level change is felt within a wider area in Currituck Sound. A large part of Currituck Sound displays limited tidal influence with a water level near $0.01 \mathrm{~m}$. B) Low tide in the ocean $(-0.5 \mathrm{~m})$ and its effects on the estuarine system. Currituck Sound experiences little change between high and low tide at this time interval; the water level remains at about $0.1 \mathrm{~m}$. C) Water current magnitude, 
with a maximum velocity of $1 \mathrm{~m} / \mathrm{s}$ directly in the inlet mouths but little influence within Currituck Sound beyond that

13. $<500$ cal y BP (modern) Delft3D model run with no inlet open north of Roanoke Island as indicated by Figure 9D. A and B) Currituck and Albemarle sounds largely maintain their respective water levels during this time slice while the water level in Pamlico Sound near Gunt/Oregon Inlet has a range of $0.1 \mathrm{~m}$. C) Water current magnitude, with a maximum velocity of $1 \mathrm{~m} / \mathrm{s}$ directly in the mouth of Gunt/Oregon Inlet and very little velocity found elsewhere throughout the system

14. White-deBry map from 1590 A.D. Delft3D model runs were produced based on the inlet configurations indicated by this map. Red box indicates the location of section modeled using Delft3D and the red arrows indicate the locations of the modeled inlets

15. 1590 A.D. Delft3D model run with Old Currituck, Caffey's, Trinity, Roanoke and paleoGunt/Oregon inlets open as indicated by the White-de Bry map (Figure 14). A) High tide in the ocean $(0.5 \mathrm{~m})$ and its effects on the estuarine system. A maximum of $0.25 \mathrm{~m}$ water level change is felt within Currituck Sound and water level changes of up to $0.5 \mathrm{~m}$ are felt close to the inlets in northern Currituck Sound and south of Roanoke Island. B) Low tide in the ocean $(-0.5 \mathrm{~m})$ and its effects on the estuarine system. Southern Currituck Sound experiences water level of $-0.25 \mathrm{~m}$ while northern Currituck Sound and Albemarle Sound experience water levels of $0.15 \mathrm{~m}$. C) Water current magnitude, with a maximum velocity of $1 \mathrm{~m} / \mathrm{s}$ directly in the inlet mouths and velocities ranging from 0.3 to $0.7 \mathrm{~m} / \mathrm{s}$ felt locally in Currituck Sound. This inlet configuration creates the largest magnitude and most widespread tidal impacts of all modeled scenarios 
16. Model estimates of current speed at vibracore sites for four time slices (Figures 9-13). Vibracore locations can be seen in Figures 2 and 9 A-D. The current velocity through time for CUR11 VC8 matches well with sediment grain-size. The current velocity for CUR11 VC 2 does not match the grain-size shown in the lithologic log. This mismatch could be due to the size, shape, location, or number of the modeled inlets ...... 


\section{Introduction}

Coastal systems are extremely dynamic; as such it is challenging to forecast how changes in sea level and storm patterns will affect such an active and evolving environment. The coastal geologic record offers the opportunity to refine forecasts as it allows assessment of process response that occurred in the past; i.e. the actual response of a coastal system to processes such as storm energy and sea-level rise. A number of papers have been published which attempt to relate the geologic character of estuaries to variances in process, particularly sea-level rise and storm impacts (Boothroyd et al. 1985; Ritchie and Penland, 1988; Oertel et al., 1992; Dalrymple et al., 1992; McBride et al., 1995; Davis et al., 2003; Fritz et al., 2007).

Early models explaining barrier island and lagoonal evolution were based upon sedimentary basins and epeiric seas (Oertel et al., 1992; Köykkä and Lamminen, 2011). Due to Holocene sea-level rise, a large percentage of coastal barrier lagoons are affected by the transgressed landscape topography, thus creating a need for a landscape topography model for lagoon evolution as opposed to the previous models based on sedimentary basins (Oertel et al., 1992).

Microtidal coastlines, such as North Carolina, have wave-dominated inlets (Davis et al., 2003). Boothroyd et al. (1985) proposed that, for a microtidal lagoon, the rate of sea-level rise as compared to the rate of sedimentation and island retreat must be balanced for the continued existence of lagoons. A higher rate of sedimentation than inundation will result in a decrease in lagoon size. McBride et al. (1995) concluded that along the coastlines of Louisiana, Mississippi, southern Georgia and northern Florida, the controlling factor on geomorphic response types for barrier islands (i.e., lateral 
movement, advance, dynamic equilibrium, retreat, in-place narrowing, landward rollover, breakup and rotational instability) is the sediment supply and, to a larger extent, the rate of relative sea-level rise.

Dalrymple et al. (1992) provided a comprehensive model of estuary type and evolution in response to sea level rise. His model provides a template for understanding the geomorphology and evolution of drowned river valley estuaries depending on the relative strength of wave, tidal, and fluvial energy. Although this model proved useful in understanding the evolution of Albemarle Sound in NC (Mallinson et al., 2005), it has not been shown to apply to shallower, back-barrier lagoons (the subject of this study).

Culver et al. (2007) and Grand Pre et al. (2011) found that the low-lying barrier islands that comprise the North Carolina coast have partially "collapsed" (i.e., large sections have been reduced to submarine shoals) and been rebuilt at least twice during the late Holocene, affecting the evolution of Pamlico Sound (Figure 1). The mechanism of barrier erosion and rebuilding is not entirely clear, but their data illustrate that the process of barrier and estuarine evolution is more complex than simple models would suggest.

The study area for this investigation, Currituck Sound an open-water-type lagoon (Oertel, 1985), is the northern end of the Albemarle-Pamlico Sound system of North Carolina (Figure 1) and is currently hydraulically isolated from the Atlantic Ocean by the Outer Banks barrier island system. The closest connection to the ocean and marine water is Oregon Inlet, approximately $40 \mathrm{~km}$ to the south. Due to the lack of inlets in the Sound, the salinity is very low, between $\sim 1$ and 4 on average. Rare instances of barrier island overwash during extreme storm events result in salinities reaching 10 (Robinson and McBride, 2003). 

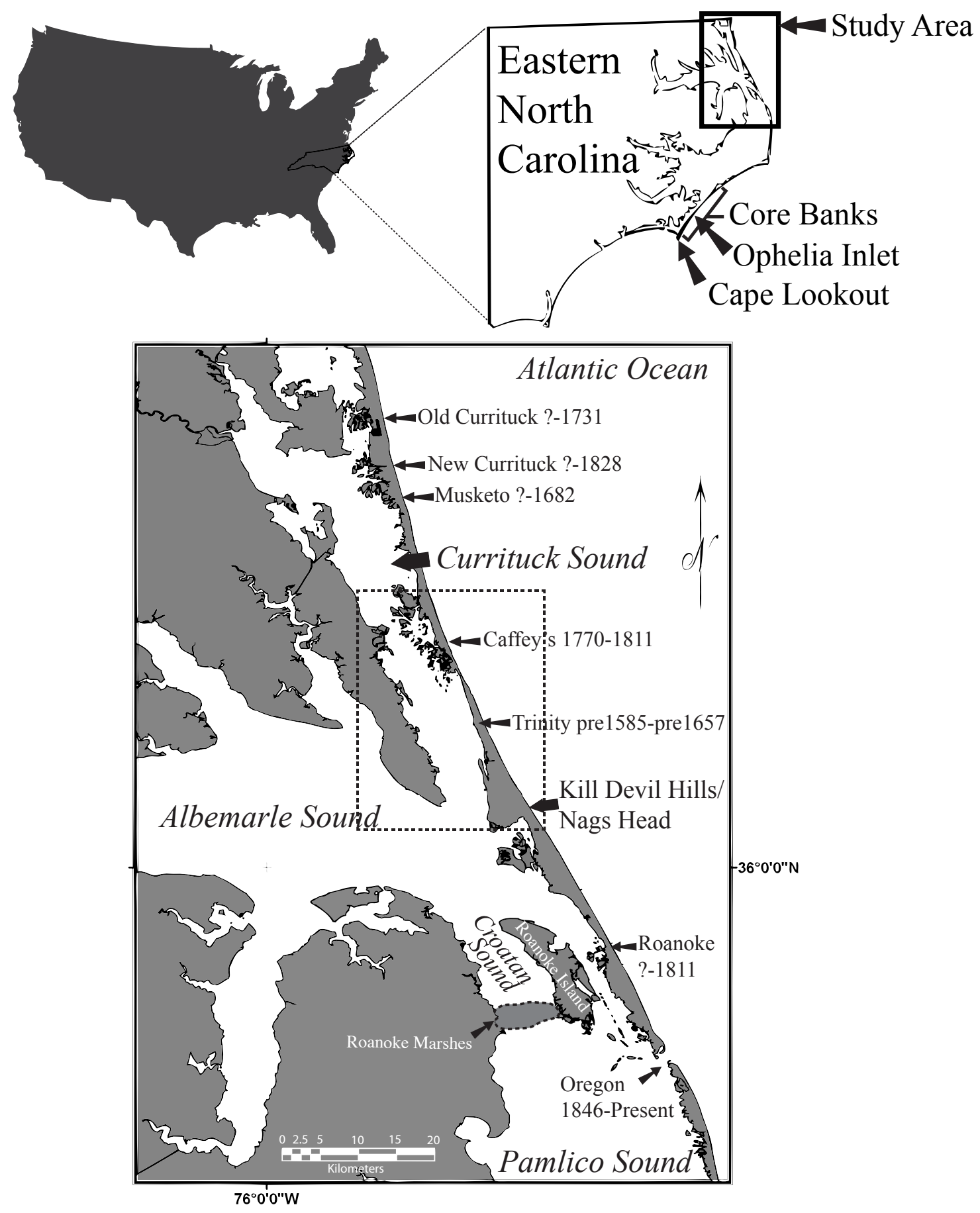

Figure 1: Map showing all known historical inlets and their opening/closing dates in northeastern North Carolina. Top left is the outline of the continental United States and top right shows eastern North Carolina with important geographic areas labeled. The dashed box indicates the location of the study area in southern Currituck Sound and the dashed circle in southern Croatan Sound is the location of the paleo-Roanoke Marshes that existed until the mid-19 century. 
Low-lying, narrow barrier islands with limited tidal flats are susceptible to inlet formation during storm events (Pierce, 1970). Throughout the Holocene evolution of Currituck Sound several inlets have opened and closed in the barrier island system allowing for changing salinity and tidal influence over time (Stick, 1958; Fisher, 1962; Robinson and McBride, 2006; and USACE, 2010). These Holocene sediments provide a record of the impacts of increased island segmentation due to sea-level change and increased storm intensity. Using geophysics, biofacies, stratigraphy, and geochronology, coupled with hydrodynamic modeling, this study enables an understanding of the evolution of Currituck Sound (Figure 1). This interpretation of the paleoshoreline, paleoinlets and tidal ranges, in response to Holocene regional climate events and sealevel change, is then compared with other studies (e.g., Riggs et al., 1992; Dalrymple et al., 1992; Oertel et al., 1992; Mallinson et al., 2005, 2010; and Culver et al., 2008, 2011). 


\section{Previous work}

Previous studies using seismic-reflection data, foraminiferal distribution, and lithofacies analysis have been fundamental in understanding the stratigraphy and evolution of the North Carolina coastal system (eg., Riggs et al., 1992; Boss et al., 2002; Mallinson et al., 2005, 2010; Culver et al., 2008).

Riggs et al. (1992) found as many as 18 Quaternary sea-level highstand events within the $60 \mathrm{~m}$ of preserved Quaternary deposits in northeastern North Carolina. That study used high-resolution seismic data, coupled with detailed litho-, bio-, and aminostratigraphic drillhole data, which indicates the presence of imbricated coastal deposits with similar, but discontinuous lithostratigraphic units (Riggs et al., 1992). Boss

et al. (2002) looked at single-channel, high-resolution, seismic reflection profiles offshore of North Carolina. Comparing the data to the existing stratigraphic data from the lagoon and barrier island system, they were able to define six Quaternary seismic reflection horizons and five stratigraphic units (Boss et al., 2002). These studies provide the initial geologic framework, both behind the barrier islands and offshore, which several other studies have since built upon. Mallinson et al. (2005) used seismic surveys throughout the eastern Albemarle Sound as well as lithostratigraphic and geochronologic data recovered from drill locations, both on the Outer Banks and in the Sound, to show that the incised, channel-fill facies of the Quaternary unconformably overlie Pliocene deposits. Holocene bay-mouth sands occur within the incised valley indicating the modern continuous barrier island system was not present during much of the Holocene.

Culver et al. (2008) further studied the Albemarle Sound area using micropaleontological data (i.e., foraminifera, pollen, and diatoms). The study showed that 
the Albemarle Sound and barrier island system has a complex Holocene evolutionary history including periods of open-marine influence followed by progressive isolation from marine waters as inlets closed down. Mallinson et al. (2010) later employed techniques similar to their 2005 study to the Pamlico Sound region and concluded that the geomorpholog(relict drainage patterns, paleotopographic highs/lows, and the locations of fluvial systems, relict inlets, and interstream divides)y and stratigraphy of the area is largely affected by the antecedent topography (relict drainage patterns, paleotopographic highs/lows, and the locations of fluvial systems, relict inlets, and interstream divides), relative sea-level change and coastal oceanographic processes.

The modern, normal marine, inner shelf and nearshore foraminiferal assemblage off northeastern North Carolina is dominated by Elphidium excavatum (Schnitker 1971). Similarly, Robinson and McBride (2008) found a Pleistocene shoreface assemblage off False Cape, in northern Currituck Sound, predominantly comprised of Elphidium excavatum with some Elphidium gunteri, Quinqueloculina seminula and Elphidium poeyanum. There is a large variation in foraminiferal species found in flood tide deltas due to the dynamic nature of deltas. Some studies, such as Vance et al. (2006) and Smith et al. (2009) found that modern flood tide deltas have low foraminiferal species richness and abundance. However, other studies, such as Grossman and Benson (1967) who looked at flood tide delta deposits from Ocracoke and Drum Inlets, found higher species richness than Vance et al. (2006) and Smith et al. (2009). Flood tide delta deposits in the Outer Banks have been characterized as having the following species of foraminifera present: Elphiduim excavatum, Quinqueloculina seminula. Cibicides lobatulus, and Hanzawaia concentrica (= Hanzawaia strattoni) (Grossman and Benson, 1967; Robinson 
and McBride, 2006; Abbene et al., 2006; Vance et al., 2006) all of which are part of a normal salinity, marine assemblage.

Assemblages containing primarily calcareous foraminifera that represent both marine and brackish environments, with a high species richness were found in Old Currituck Inlet deposits near the North Carolina/Virginia border by Robinson and McBride (2006) and on the modern flood tide deltas of Hatteras and Ocracoke inlets by Abbene et al. (2006). These deposits contained species such as Buccella frigida, Cibicides lobatulus, Hanzawaia strattoni, Quinqueloculina seminula, Elphidium galvestonense, Elphidium mexicanum, Elphidium subarcticum and Elphidium excavatum.

Nichols and Norton (1969) described biofacies containing Elphidium species as higher brackish conditions $(>14)$ in the James River Estuary of southern Virginia and Cronin et al. (2003) noted that Elphidium species were only found when the salinity was greater than 10 in the Chesapeake Bay. Abbene et al. (2006) demonstrated that a higher relative abundance of Elphidium excavatum and Ammonia parkinsoniana is indicative of a high salinity, brackish biofacies in Pamlico Sound.

Vance et al. (2006) conducted a study in the Albemarle and adjacent sounds and defined estuarine shoal, and estuarine biofacies, both dominated by Ammobaculites crassus and Ammotium salsum. The surface samples collected in Currituck Sound were largely dominated by Ammobaculites crassus, Ammontium salsum and Miliammina fusca with smaller proportions of Ammobaculites subcatenulatus and Miliammina petila present. Grossman and Benson (1967) noted that Ammobaculites species are typical of low salinity waters and Nichols and Norton (1969) stated that, in the James River 
Estuary, biofacies dominated by Ammobaculites are typical of low brackish conditions (e.g., $0.5-14)$.

Foraminiferal and sedimentological data are commonly used for Holocene paleoenvironmental reconstruction (e.g., Hippensteel and Martin, 1999; Abbene et al., 2006; Culver et al., 2006; Robinson and McBride, 2006; Vance et al., 2006; Smith et al., 2009; Mallinson et al., 2010; Grand Pre et al., 2011; Leorri and Cearreta, 2004).

Foraminiferal assemblages are indicative of specific environments within the coastal system. Modern foraminiferal assemblages can be compared to those found down-core in order to interpret the depositional environment. Several studies focusing on the Outer Banks have employed this methodology (Culver and Horton, 2005; Abbene et al., 2006; Culver et al., 2006, 2007; Robinson and McBride, 2006; Mallinson et al., 2010; Grand Pre, 2011).

\section{a. Hydrodynamic Modeling}

Hydrodynamic models are important tools used to analyze erosion problems, assess morphological impacts of human interference and to aid in the design of coastal defenses (Lesser et al., 2004). Lesser et al. (2004) show that the DELFT3D model performs well in several theoretical, laboratory, and realistic situations and recounts several other validation studies. This modeling package is capable of calculating the hydrodynamics of the water as well as the fate and transport of variables in the water column such as sediment, salinity, heat, etc.

DELFT3D has been used to model the Texel Inlet in the Dutch Wadden Sea after drastic changes occurred to the tidally influenced inlet (Elias et al., 2006). In quasi realtime simulation of the dominant flow and transport patterns over a three-month period, 
Elias et al. (2006) concluded that the model was able to simulate the dominant features in the flow and transport patterns in the ebb-tidal delta domain. The ADCIRC coastal circulation and storm surge model has also been used to look at the North Carolina coast (Luettich et al., 2002) to simulate tidal and wind-driven flows for present-day bathymetry. The findings indicate that astronomical tides have very little impact on the Albemarle and Pamlico Sounds, due to the Outer Banks, and cite wind forcing as the major control over the tidal forcing in the system. Lentz (2001) used modeling to look at the wind-driven, cross-shelf circulation off of the coast of North Carolina. The study concluded that when the water column was stratified, as in summer months, up- and down welling occur within $10 \mathrm{~km}$ of the coast. In the winter months, when the water column is not stratified, up- and down welling occurs ca. $40 \mathrm{~km}$ off the coast, near the shelfbreak. Leorri et al. (2011) used Delft3D modeling to look at the impacts of sea-level rise on tidal range. The model, while quite basic as far as inputs (modern bathimetry with a uniform tidal forcing), shows that a tidal range of $0.5 \mathrm{~m}$ over the late Holocene impacts local trends in tidal range. 


\section{Study Area}

The coastal zone of northeast North Carolina is characterized by a thick Quaternary sequence that fills a regional depositional basin called the Albemarle Embayment; this embayment runs under the northern Pamlico Sound through the eastern Albemarle Sound (Riggs et al., 1995; Mallinson et al., 2005, 2010) (Figure 1).

North of Cape Lookout, the North Carolina barrier island system is generally low, narrow, and extends for about $300 \mathrm{~km}$ along the northeast North Carolina coast with only four inlets dissecting the barrier island system (Stick, 1958; Fisher, 1962; and Culver et al., 2007). Culver et al. (2007) and Grand Pre et al. (2011) suggested that over the history of the barrier island system there have been times when parts of the barrier island system have eroded below sea level and other times when they run the entire length of the North Carolina coast with few inlets. Mallinson et al. (2011) showed a relationship between the number of inlets and paleoclimate events (i.e., the Medieval Warm Period and the Little Ice Age). These studies indicate that there were times in the past that the Albemarle and Pamlico Sounds were open to the ocean, resulting in very different environmental conditions within the estuaries.

Currituck Sound is the northernmost estuarine component of the AlbemarlePamlico Sound system of North Carolina (Figure 1). It is approximately $58 \mathrm{~km}$ long and 5 to $13 \mathrm{~km}$ wide with a mean depth of $1.5 \mathrm{~m}$ (USACE, 2010) and is separated from the Atlantic Ocean by the Outer Banks, a narrow barrier island system.

Historically, (post AD 1585), several inlets connected Currituck Sound to the Atlantic Ocean: Old Currituck Inlet, New Currituck Inlet, Musketo Inlet, Trinity Inlet and 
Caffey's Inlet (Figure 1) (Stick, 1958; Fisher, 1962; Robinson and McBride, 2006;

USACE, 2010). The opening and closing of these inlets occurred from the early 1600 's through the late 1820 's when the last naturally occurring inlet, New Currituck Inlet, closed around 1828 (Stick, 1958; Fisher, 1962; and USACE, 2010). Roanoke Inlet, further south (Figure 1), was also open until 1811 and may have influenced hydrodynamics within the Currituck Sound region. Furthermore, Culver et al. (2008) showed relict inlets occurring in the Nags Head region, which were likely open between 5000 cal y BP and 1000 cal y BP.

The waters in Currituck Sound have varied from fresh to saline depending on inlet formation (Stick, 1962), storm events, and human interactions such as the construction of the intracoastal waterway (USACE, 2010). At present, hydraulic connections between Currituck Sound and the Atlantic Ocean are remote and limited to Oregon Inlet approximately $40 \mathrm{~km}$ to the south. Thus, Currituck Sound currently has very low salinity ranging from 2-3 in the northern end and 4-5 in the southern end and up to 10 during large storm events with overwash (Robinson and McBride, 2006). Coastal North Carolina is a microtidal, wave-dominated system. The mean tidal range is $1.0 \mathrm{~m}$ (Moslow and Tye, 1985) significant wave height is $1 \mathrm{~m} \pm 0.6 \mathrm{~m}$ (Moslow and Tye, 1985).

The field area of collected data, both geophysical and sedimentological, was confined to the southern end of Currticuk Sound, just south of the flood tide delta created by historic Caffey's Inlet and just north of the Kill Devil Hills/ Nags Head area. The modeled area was much larger than the area of collected data. It ranged from the North Carolina/Virginia boarder in the north, including the northern end of Currituck Sound, to 
just south of modern day Oregon Inlet in the south. The models included the entire Albemarle Sound and extended to the shelfbreak in the east. 


\section{Methods}

\section{a. Geophysics}

In the fall of 2010 and the spring of 2011, seismic data were collected in Currituck Sound (Figure 2) using an EdgeTech Chirp 2-16 kHz sub-bottom profiling system. Data were analyzed using Seismic Micro-Technology (SMT) Kingdom Suite Software (v. 8.2 and 8.6). Reflections were digitized to provide the late Pleistocene and Holocene seismic stratigraphic framework including paleovalleys, fluvial channels, tidal channels and the westward extent and characteristics of the Holocene transgressiveravinement surface and associated shoreline. The seismic data provide a framework for vibracore correlations and paleoenvironmental reconstruction.

\section{b. Coring}

Thirteen vibracores $(8.9 \mathrm{~cm}$ in diameter and $1.9 \mathrm{~m}$ to $6.1 \mathrm{~m}$ in length) were collected throughout the study area during the spring and summer of 2011 (Figure 2). Coring locations were chosen along the chirp seismic transects in strategic places to target specific seismically-defined horizons and facies.

\section{c. Lithofacies}

Vibracores were split, photographed and logged using a method set adapted from Folk (1974). Descriptions of the cores included color, grain size, composition, sorting, and sedimentary structures. Seventy-seven and sixty-four two-cm samples for foraminiferal and grain size analyses, respectively, were collected at depths of major lithological changes within the cores. Standard sieve and Rotap methods were used to give detailed analysis of grain size of distinctive lithofacies. Samples were extracted from the cores, dried at $40^{\circ} \mathrm{C}$ for 24 hours, and dry-sieved for 15 minutes using a Rotap and stacked 
sieves ranging from -2.0 to 4.0 phi with intervals of 0.5 phi. Weight percentages and statistics were then calculated using GRADISTAT software (Blott and Pye, 2001) to determine sorting, skewness, mean and median grain size data.

\section{d. Biofacies}

Sediment samples for foraminifera were collected from each lithofacies of the core; the samples were dried at $60^{\circ} \mathrm{C}$, weighed and then dispersed in beakers using water and sodium hexametaphosphate to disaggregate the samples. After wet sieving over 63 and 710-micron sieves to remove the silt and clay, the remaining sand and gravel fractions were dried and re-weighed to determine the gravel-sand-mud ratio. The sodium polytungstate sink-float method described by Munsterman and Kerstholt (1996) was used to concentrate the foraminifera in the sand fractions. Approximately 100 specimens per sample were randomly picked and then identified to the species level by comparison with images of foraminifera in the published literature. Identifications were confirmed via comparisons with type specimens held in the Smithsonian Institution's Cushman Collection in Washington, D.C. Foraminiferal biofacies were determined using cluster analysis (Mello and Buzas 1968).

\section{e. Hydrodynamic Modeling}

Using DELFT3D, a modern geomorphic grid with $100 \mathrm{~m}$ resolution was developed for the coastal region of North Carolina and was modified to include only Currituck Sound and Albemarle Sound (Figure 3) ending just south of Roanoke Island. The southern boundary of Roanoke Island was chosen due to the presence of the Roanoke Marshes, which connected southern Roanoke Island to the mainland until the mid 1800's (Stick, 1958) when the marshes were breached and Croatan Sound was formed (Figure1). 


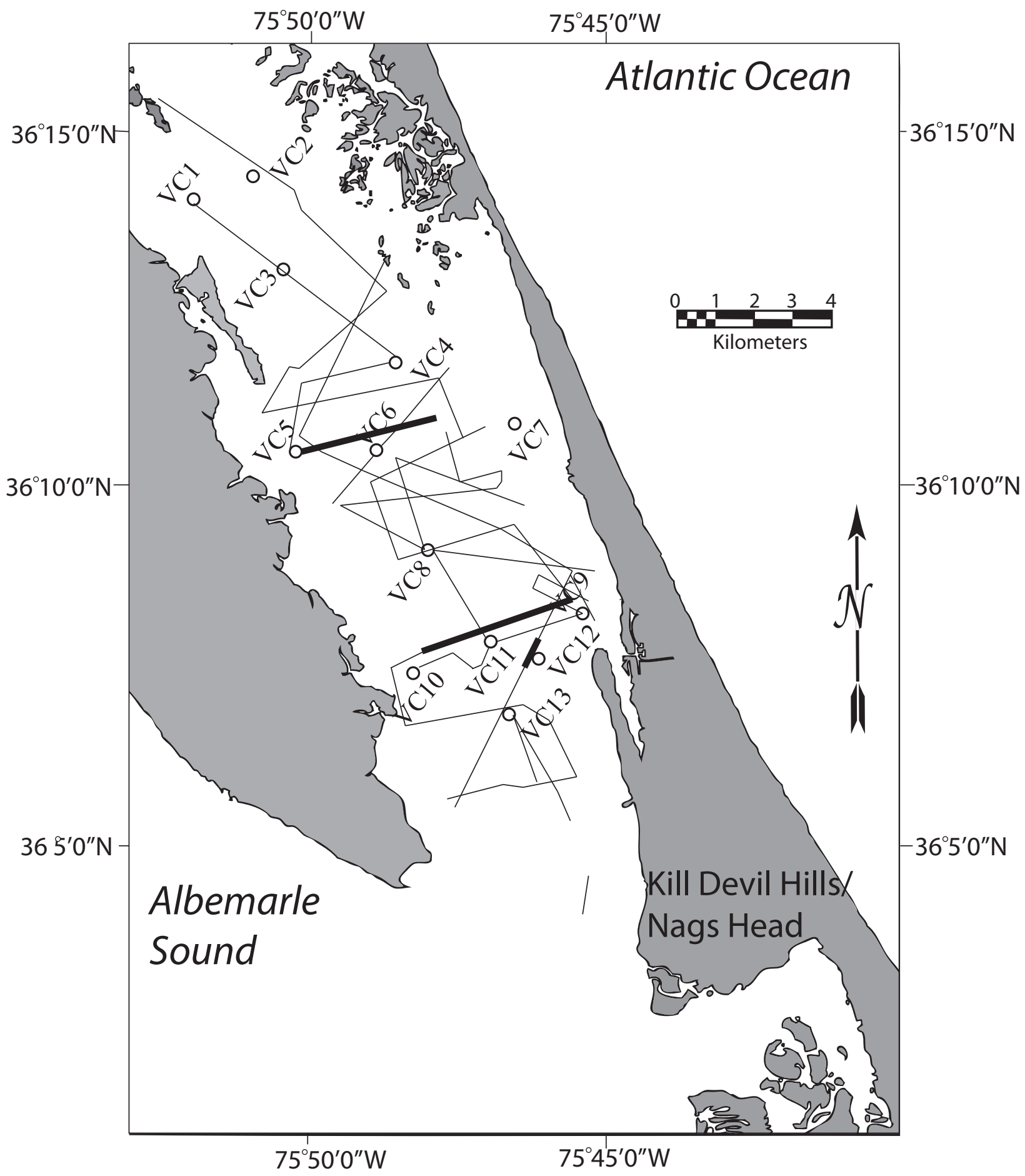

Figure 2: Map showing Chirp survey lines in Southern Currituck Sound. The bold lines are seismic sections presented in Figures 4, 5 and 6. The circles are locations of vibracores (VC). 
Prior to the formation of Croatan Sound, Albemarle Sound and Pamlico Sound were essentially unconnected estuarine systems. A M2 microtidal amplitude of $0.5 \mathrm{~m}$ was implemented at the eastern boundary the geomorphic grid (Lentz, 2001), which is located offshore along the shelf break, and default model parameters were used (Delft Hydraulics, 2006).

All model scenarios were run at a time step of 1 minute for a duration of 18 days. This was done to allow for 13 days of model spin-up, and the final 5 days of steady-state tidal flow were used in the analysis. A modern scenario was run, with modern bathymetry data as well as the modern configuration of the barrier islands and associated inlets. The simulated water level elevations were compared to real-time data collected by the Duck Research Facility and the USACE in Currituck Sound, North Carolina.

Time slices $(\sim 5000-3000$ cal y BP, $\sim 3000-1000$ cal y BP, $\sim 1000-500$ cal y BP, $<500$ (Modern Scenario), and 1590 (White-deBry Map) were chosen based on the geologic and paleoenvironmental interpretations of the Sound as well as an early map of North Carolina. The grid was then modified for each of the pre-determined time slices to include the inlets. Ophelia Inlet on Core Banks, the southernmost part of the Outer Banks, was used as a modern analog for the paleoinlets due to its abrupt formation during storm activity (Mallinson et al., 2011). The dimensions of Ophelia Inlet were used as input for the model reconstruction. All inlets were a uniform width of $0.5 \mathrm{~km}$ and a depth of $6 \mathrm{~m}$ with the exception of the inlet in the $\sim 5000-3000$ cal y BP time slice, which is 1 $\mathrm{km}$ wide with a depth of $6 \mathrm{~m}$ (based on data from Mallinson et al. $(2005,2010)$ and Culver et al. (2008)). All time slices were run with the same parameters and once the runs were complete, data from each core location was exported from Delft3D for use in 


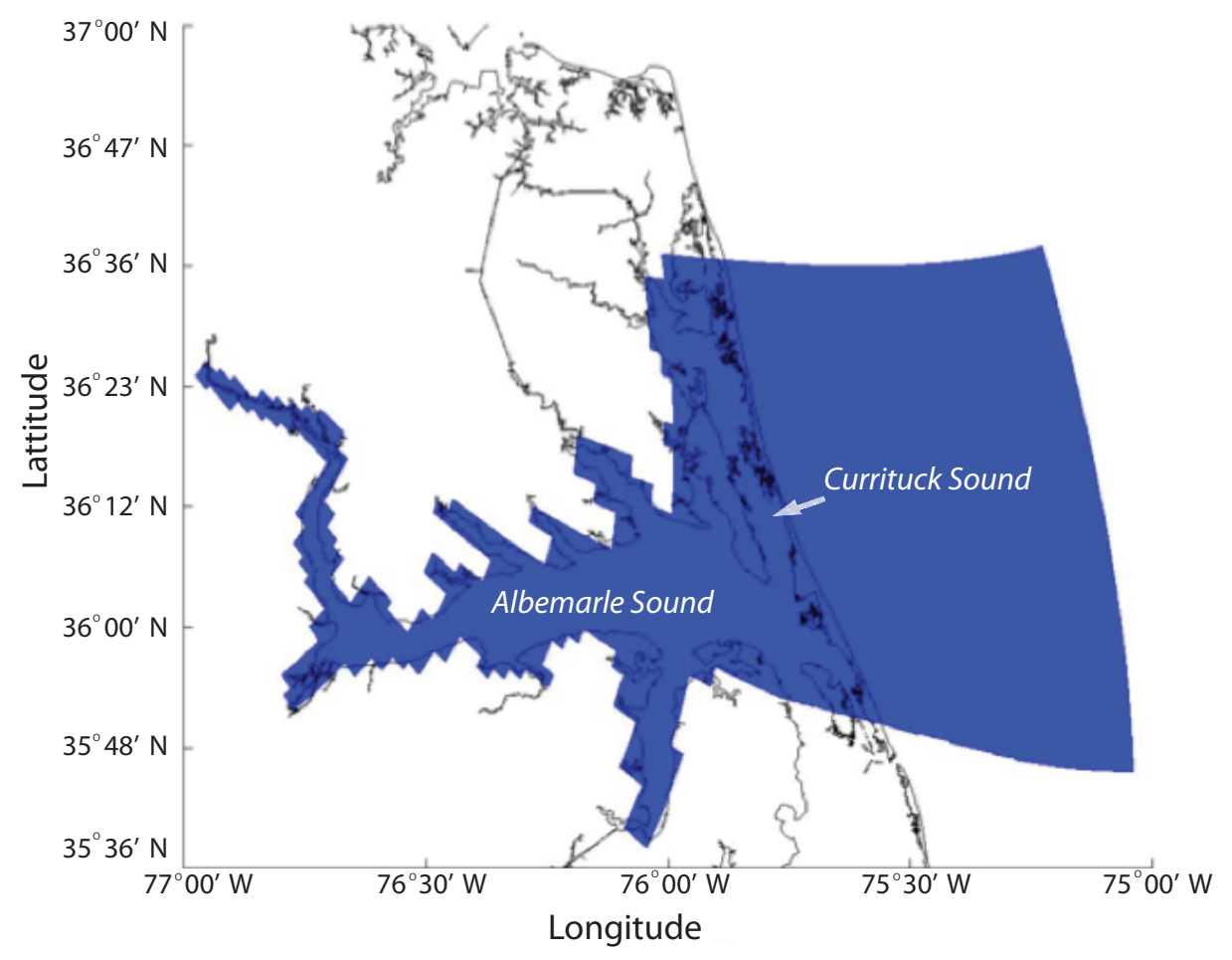

Figure 3: The extent and shape of the geomorphic grid show overlain a map of Currituck and Albemarle Sounds. The grid has a resolution of $100 \mathrm{~m}$. 
Matlab. Current velocity data were exported in vector format and imported into Matlab. The root mean square (rms) current velocity in $\mathrm{m} / \mathrm{s}$ was determined using the following equation:

$$
[(\mathrm{VCx}) \text { y comp }]^{2}+[(\mathrm{VCx}) \mathrm{x} \mathrm{comp}]^{2}=[(\mathrm{VCx}) \mathrm{rms}]^{2}
$$

where (VCx) $\mathrm{x}$ comp is the current velocity in the $\mathrm{x}$ direction at the vibracore (VC) $\mathrm{x}$, (VCx) y comp is the current velocity in the y direction at the vibracore (VC) $\mathrm{x}$ and (VCx)rms is the magnitude of the current velocity measured at the vibracore (VC)x. The tidal amplitude at each vibracore was determined for each model run, and was expressed as a percentage of the tidal forcing at the model boundary.

\section{f. Age Analysis}

Radiocarbon and optically stimulated luminescence (OSL) data provided the chronostratigraphic framework for the cores and geophysical data. Radiocarbon ages were determined from roots and articulated bivalve shells. Seven samples were analyzed at Beta Analytic and calibrated to produce calendar years data (cal yr BP), and are presented as 2-sigma ranges throughout this manuscript (Stuiver and Reimer, 1993; Stuiver et al., 1998).

Samples were collected for OSL analyses by cutting, splitting, and sampling a core section under dark-room conditions (low energy red light). Two quartz sanddominated samples were sent to Utah State University Luminescence Laboratory for OSL analysis using the single aliquot regenerative (SAR) method. Preparation followed the general procedures outlined in Mallinson et al. (2011). OSL ages are converted to cal yr 
BP by subtracting 62 years (samples were analyzed in 2012). All OSL data are presented as 1-sigma age ranges. 


\section{Results}

\section{a. Age Analysis}

Seven samples were taken from six different cores and were analyzed by Beta Analytic. Five of the seven samples consist of articulated oyster shells and two were pieces of wood from large $($ several $\mathrm{cm})$ roots giving a range in ages from a maximum of 4080 to a minimum of 540 cal y BP (Table 1). Samples from CUR11 VC4 and CUR11 VC12 were analyzed for OSL age estimates; the ages recovered were Pleistocene $(33.7 \pm$ $3.81 \mathrm{ka})$ and Holocene $(4.5 \pm 0.43 \mathrm{ka})$ respectively (Table 2$)$.

Table 1: Radiocarbon age estimates.

\begin{tabular}{|c|c|c|c|c|c|c|}
\hline $\begin{array}{c}\text { Core } \\
\text { Location }\end{array}$ & Depth in Core & $\begin{array}{c}\text { Depth Below } \\
\text { MSL }\end{array}$ & Material Dated & ${ }^{14} \mathrm{C}$ age $\pm 2 \sigma$ & $\delta^{13} \mathrm{C}$ & $\begin{array}{c}2 \sigma \text { Calibrated } \\
\text { Age Range }\end{array}$ \\
\hline $\begin{array}{c}\text { CUR11 } \\
\text { VC2 }\end{array}$ & $160 \mathrm{~cm}$ & $3.20 \mathrm{~m}$ & Oyster & $1330 \pm 30 \mathrm{BP}$ & $\begin{array}{c}-3.0 \\
\text { o/oo }\end{array}$ & $\begin{array}{c}1290 \text { to } 960 \\
\text { cal y BP }\end{array}$ \\
\hline $\begin{array}{c}\text { CUR11 } \\
\text { VC3 }\end{array}$ & $51 \mathrm{~cm}$ & $3.25 \mathrm{~m}$ & Oyster & $830 \pm 30 \mathrm{BP}$ & $\begin{array}{c}-0.5 \\
\text { o/oo }\end{array}$ & $\begin{array}{c}840 \text { to } 550 \mathrm{cal} \\
\text { y BP }\end{array}$ \\
\hline $\begin{array}{c}\text { CUR11 } \\
\text { VC3 }\end{array}$ & $66 \mathrm{~cm}$ & $3.40 \mathrm{~m}$ & Wood & $2780 \pm 30 \mathrm{BP}$ & $\begin{array}{c}-24.9 \\
\text { o/oo }\end{array}$ & $\begin{array}{c}2950 \text { to } 2790 \\
\text { cal y BP }\end{array}$ \\
\hline $\begin{array}{c}\text { CUR11 } \\
\text { VC4 }\end{array}$ & $100 \mathrm{~cm}$ & $3.75 \mathrm{~m}$ & Oyster & $1570 \pm 30 \mathrm{BP}$ & $\begin{array}{c}-1.3 \\
\text { o/oo }\end{array}$ & $\begin{array}{c}1580 \text { to } 1260 \\
\text { cal y BP }\end{array}$ \\
\hline $\begin{array}{c}\text { CUR11 } \\
\text { VC6 }\end{array}$ & $320 \mathrm{~cm}$ & $5.90 \mathrm{~m}$ & Wood & $3680 \pm 30 \mathrm{BP}$ & $\begin{array}{c}-26.7 \\
\text { o/oo }\end{array}$ & $\begin{array}{c}4080 \text { to } 3890 \\
\text { cal y BP }\end{array}$ \\
\hline $\begin{array}{c}\text { CUR11 } \\
\text { VC8 }\end{array}$ & $163 \mathrm{~cm}$ & $5.20 \mathrm{~m}$ & Oyster & $1690 \pm 30 \mathrm{BP}$ & $\begin{array}{c}-1.2 \\
\text { o/oo }\end{array}$ & $\begin{array}{c}1720 \text { to } 1350 \\
\text { cal y BP }\end{array}$ \\
\hline $\begin{array}{c}\text { CUR11 } \\
\text { VC12 }\end{array}$ & $99 \mathrm{~cm}$ & $3.90 \mathrm{~m}$ & Oyster & $850 \pm 30 \mathrm{BP}$ & $\begin{array}{c}-2.7 \\
\text { o/oo }\end{array}$ & $\begin{array}{c}820 \text { to } 540 \mathrm{cal} \\
\text { y BP }\end{array}$ \\
\hline
\end{tabular}

Table 2: Optically Stimulated luminescence age estimates.

\begin{tabular}{|l|l|l|l|l|l|l|l|l|l|l|}
\hline Sample ID & $\begin{array}{l}\text { Lab } \\
\#\end{array}$ & $\begin{array}{l}\text { Depth in } \\
\text { core } \\
(\mathrm{cm})\end{array}$ & Lat. & Long. & $\begin{array}{l}\text { U } \\
(\mathrm{ppm})\end{array}$ & $\begin{array}{l}\text { Th } \\
(\mathrm{ppm})\end{array}$ & K (\%) & $\begin{array}{l}\text { Dose rate } \\
(\mathrm{Gy} / \mathrm{ka})\end{array}$ & $\begin{array}{l}\text { Paleodos } \\
\mathrm{e}(\mathrm{Gy})\end{array}$ & $\begin{array}{l}\text { Age (ka) } \\
2 \text {-sigma } \\
\text { error }\end{array}$ \\
\hline $\begin{array}{l}\text { CUR11VC4 Sec1 } \\
121-141 \mathrm{~cm}\end{array}$ & $\begin{array}{l}\text { USU } \\
-976\end{array}$ & 315 & 36.19569 & -75.79712 & $0.5 \pm 0.1$ & $3.4 \pm 0.3$ & $0.52 \pm 0.01$ & $0.20 \pm 0.02$ & $\begin{array}{l}27.94 \pm \\
2.24^{3}\end{array}$ & $\begin{array}{l}33.73 \pm \\
3.81\end{array}$ \\
\hline $\begin{array}{l}\text { CUR11VC12 Sec1 } \\
108-128 \mathrm{~cm}\end{array}$ & $\begin{array}{l}\text { USU } \\
\text {-977 }\end{array}$ & 273 & 36.12565 & -75.76301 & $0.6 \pm 0.1$ & $2.0 \pm 0.2$ & $0.66 \pm 0.02$ & $0.08 \pm 0.01$ & $\begin{array}{l}3.67 \pm \\
0.20^{4}\end{array}$ & $\begin{array}{l}4.54 \pm \\
0.43\end{array}$ \\
\hline
\end{tabular}




\section{g. Geophysics}

Within the seismic data seven regionally continuous to semi-continuous reflections were recognized (P1, P2, P3, $\mathrm{H}_{\mathrm{MRS}}, \mathrm{H}_{\mathrm{SF}}, \mathrm{H} 0$ and $\left.\mathrm{H} 1\right)$ (Table 3; Figure 4). P1 and $\mathrm{P} 2$ are medium to high amplitude, semi-continuous reflections. $\mathrm{P} 1$, ranging from 13 $\mathrm{m}$ below sea level in the west and $16 \mathrm{~m}$ below sea level in the east, is a strong reflection indicating a contact within Pleistocene sediment. The seismic reflection P1, as presented here, correlated to Q50 of Mallinson et al. (2010) and Culver et al. (2011) which is a Pleistocene marine ravinement surface produced by sea-level rise associated with the marine isotope stage 6 to 5 transition (i.e. Termination 2). P2, ranging from $9 \mathrm{~m}$ below sea level in the west and $13 \mathrm{~m}$ below sea level in the east, is interpreted as a Pleistocene ravinement surface due to its truncation of P1 (Figure 4). P3 occurs in the center of Currituck Sound and is a Pleistocene fluvial channel ranging from 6 to $12 \mathrm{~m}$ below sea level. H0, ranging from 2 to $8 \mathrm{~m}$ below sea level, is a high amplitude, discontinuous reflection. Based on the geophysical data and correlations to core data (e.g., CUR11 VC12), H0 is interpreted as a bay ravinement surface incised to depths of ca. $10 \mathrm{mbsl}$, and represents the Holocene/Pleistocene contact. $\mathrm{H}_{\mathrm{SF}}$ is confined to the eastern edge of Currituck Sound and is a tidally ravined surface into a sand flat or flood tide delta (Figures 4 and 5). Channelization ranges from $2 \mathrm{~m}$ to $10 \mathrm{~m}$ below sea level. $\mathrm{H}_{\mathrm{MRS}}$, also confined to the eastern edge of the Sound, is the marine ravinement surface and shows the westward extent of the Pleistocene shoreface. $\mathrm{H} 1$ is a medium amplitude, continuous reflection that appears to correlate to a widespread mostly articulated oyster shell layer within the Holocene section; this shell layer is found in several cores throughout the 
sound, including CUR11 VC6, and indicates the transition from a high brackish environment (Unit III) to a mid/low brackish environment (Unit IV) (Figure 4).

Table 3: Seismic reflections and interpretations

\begin{tabular}{|c|c|}
\hline $\begin{array}{l}\text { Reflection } \\
\text { Name }\end{array}$ & Description \\
\hline H1 & $\begin{array}{l}\text { A regionally continuous reflection that correlates to the transition between high } \\
\text { (Unit III) and low Unit IV) brackish environments }\end{array}$ \\
\hline $\mathrm{H}_{\mathrm{SF}}$ & $\begin{array}{l}\text { A reflection confined to the eastern edge of Currituck Sound that correlates to a } \\
\text { tidally ravined sand flat or flood tide delta }\end{array}$ \\
\hline $\mathrm{H} 0_{\text {MRS }}$ & $\begin{array}{l}\text { A reflection confined to the eastern edge of Currituck Sound that correlates to the } \\
\text { marine ravinement surface }\end{array}$ \\
\hline H0 & $\begin{array}{l}\text { A reflection found in the center and west of Currituck Sound correlating to bay } \\
\text { ravinement }\end{array}$ \\
\hline P3 & $\begin{array}{l}\text { A reflection in the center of Currituck Sound that correlates to Pleistocene } \\
\text { channelization }\end{array}$ \\
\hline P2 & $\begin{array}{l}\text { A regionally continuous Pleistocene reflection that truncates P1 implying a } \\
\text { ravinement surface }\end{array}$ \\
\hline P1 & A regionally continuous Pleistocene reflection \\
\hline
\end{tabular}

Figures $4 \mathrm{~A}$ and $4 \mathrm{~B}$ are west-east seismic transects displaying an eastward dipping P1 truncated by P2. P3 shows incised channels, only in the center of the Currituck Sound, that are then truncated by $\mathrm{H} 0 . \mathrm{H}_{\mathrm{SF}}$ exhibits extensive channelization on the eastern edge of Currituck Sound while $\mathrm{H}_{\mathrm{MRS}}$ is the Holocene marine ravinement surface displaying the westward extent of the shoreline. H1 tends to be present in the center of the Sound and is very close to the surface. Figure 5 shows the correlation between CUR11 VC 12 and the seismic chirp data CUR2010-5. There is a probable oyster bioherm in the center of a channel with on- and off-lapping clinoforms that in-fill the channel. Figure 6 shows the correlation between CUR11 VC 6 and the seismic chirp data CUR2010-15. H0 creates a channel which is in-filled with tidally influenced, southwest trending clinoforms of interbedded slightly muddy sand and sand. 


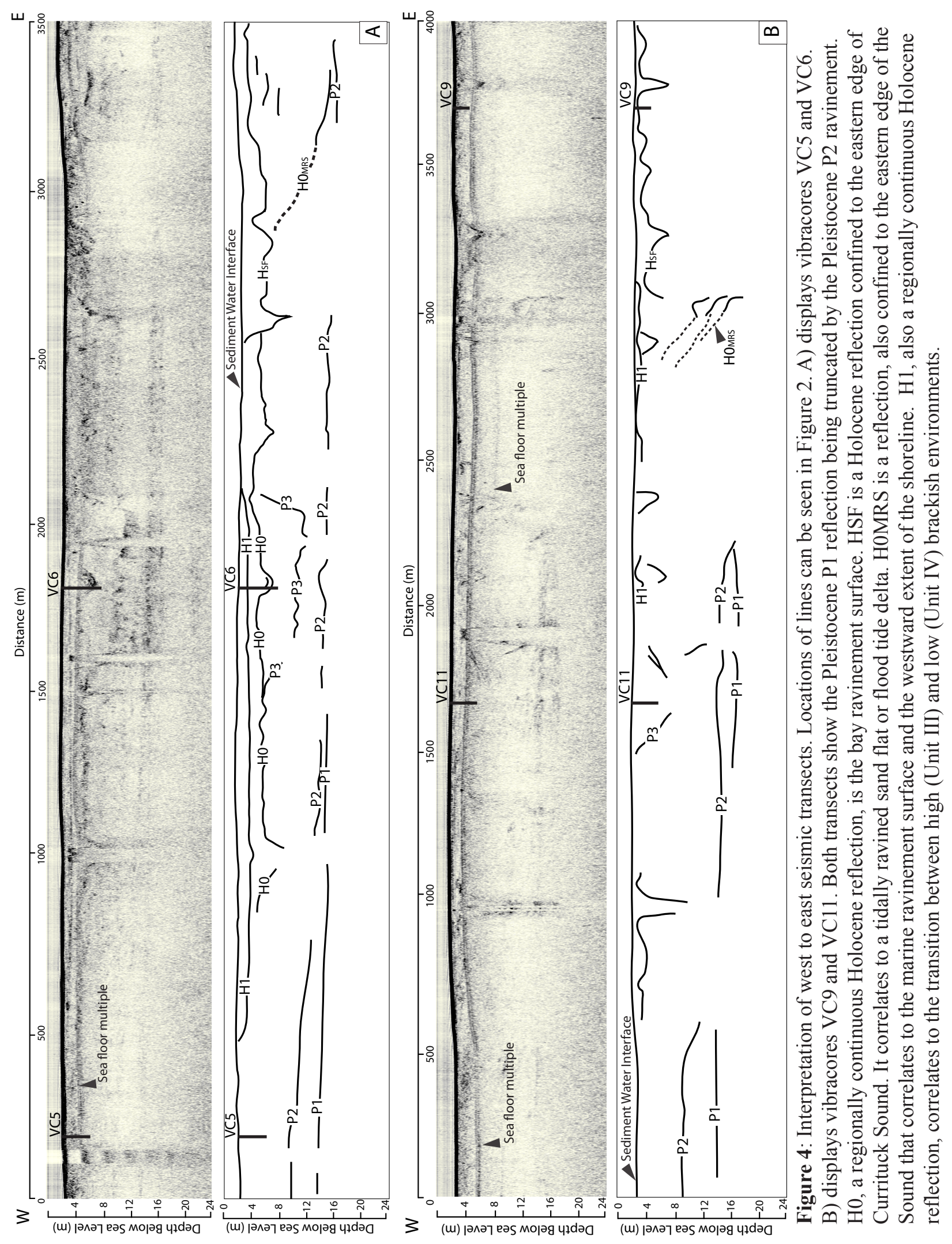



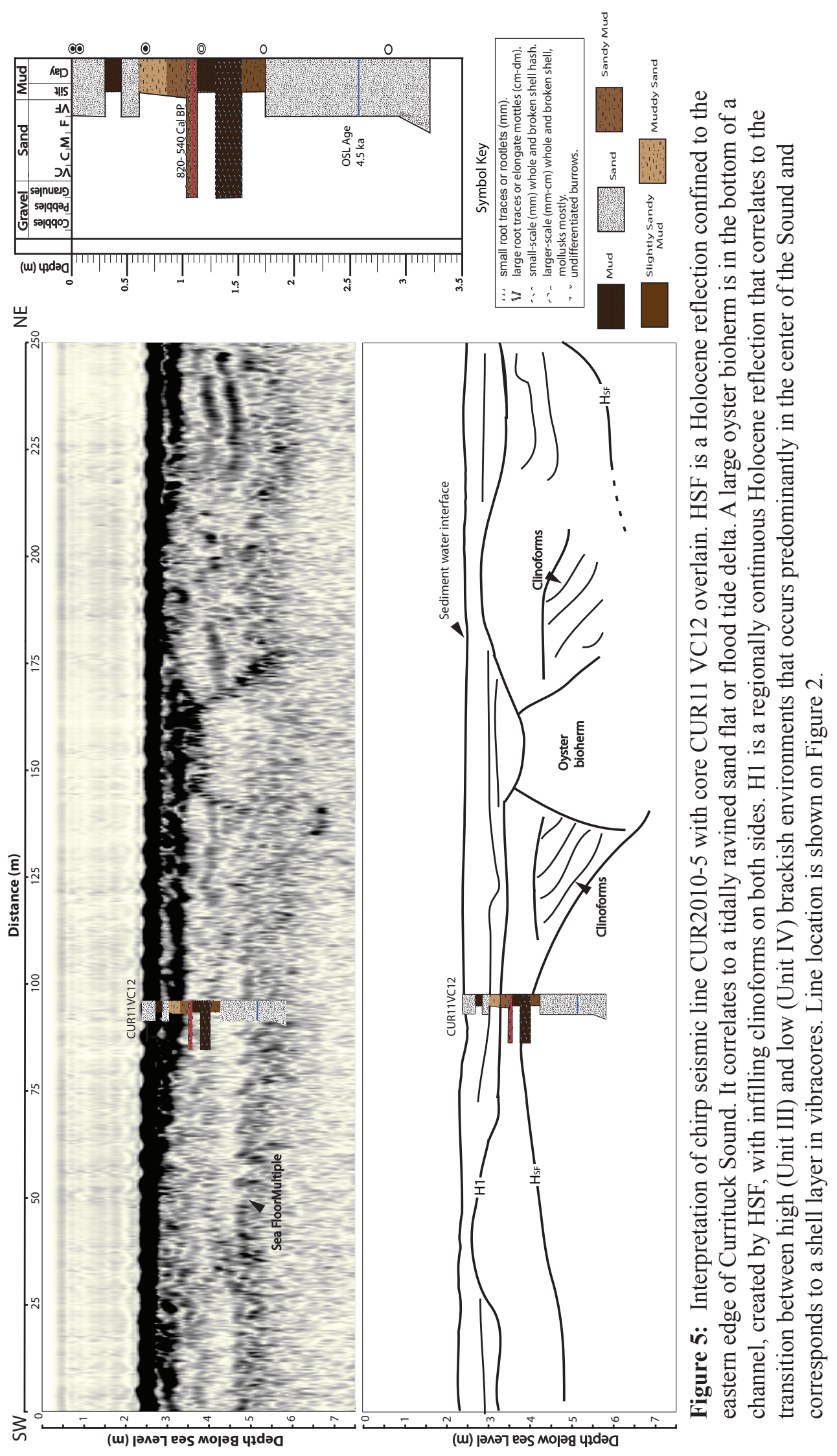


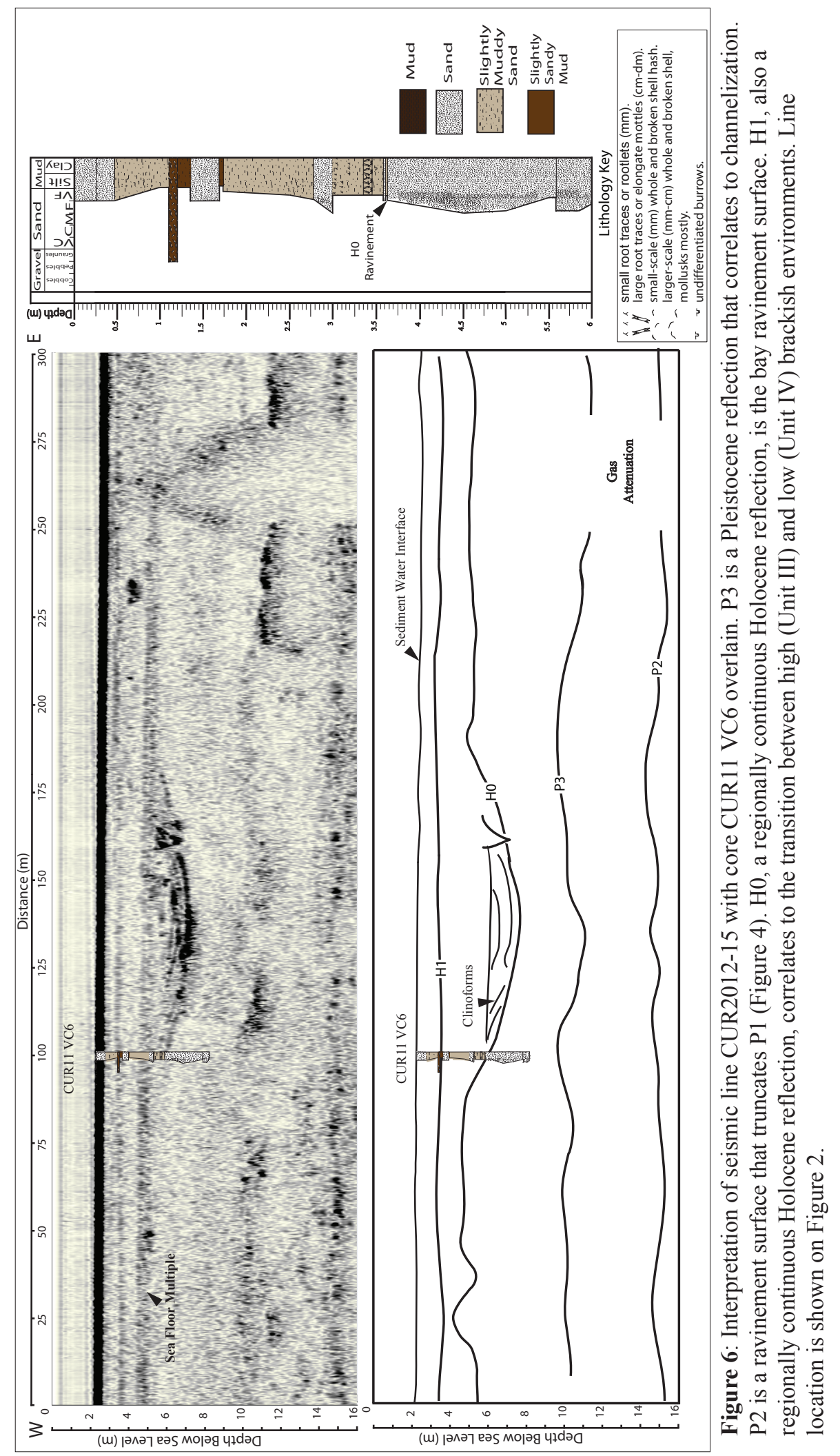




\section{h. Lithofacies and Biofacies}

In general, all thirteen vibracores display a moderately- to well-sorted fine sand unit at the bottom with a general fining-up sequence. These sand units, however, are not all coeval. There is also a widespread oyster unit throughout the Sound, ranging from large in situ oysters to shell hash, with a maximum age of ca. 1720 cal y BP and a minimum age of ca. 540 cal y BP. Table 4 lists nine lithofacies and their characteristics.

Table 4: Summary characteristics of lithofacies recorded in thirteen vibracores.

\begin{tabular}{|c|c|c|c|}
\hline Lithofacies Name & Color & Description & Sedimentary Features \\
\hline $\begin{array}{l}\text { Sand } \\
(\mathrm{S})\end{array}$ & Pinkish gray & $\begin{array}{l}\text { Very well sorted, } \\
\text { subangular, } \\
\text { fine grained sand }\end{array}$ & Massive \\
\hline Muddy sand (mS) & $\begin{array}{l}\text { Brownish yellow; } \\
\text { dark gray }\end{array}$ & $\begin{array}{l}\text { Poorly to moderately sorted, } \\
\text { subrounded to subangular, } \\
\text { fine to very fine grained sand }\end{array}$ & Bioturbated \\
\hline $\begin{array}{l}\text { Slightly muddy } \\
\text { sand } \\
(\mathrm{smS})\end{array}$ & $\begin{array}{l}\text { Grayish brown; } \\
\text { light brownish } \\
\text { gray }\end{array}$ & $\begin{array}{l}\text { Poor to moderately sorted, } \\
\text { subrounded to subangular, } \\
\text { fine grained sand }\end{array}$ & $\begin{array}{l}\text { Minor bioturbation, } \\
\text { heavy mineral laminations } \\
\qquad(1-4 \mathrm{~cm})\end{array}$ \\
\hline $\begin{array}{l}\text { Sandy mud } \\
\text { (sM) }\end{array}$ & $\begin{array}{l}\text { Medium dark } \\
\text { gray; dark gray }\end{array}$ & $\begin{array}{l}\text { Poorly sorted, } \\
\text { subrounded to subangular, } \\
\text { very fine grained sand to silt }\end{array}$ & Bioturbated \\
\hline $\begin{array}{l}\text { Shelly sandy mud } \\
\text { (shsM) }\end{array}$ & $\begin{array}{l}\text { Dark reddish } \\
\text { brown }\end{array}$ & $\begin{array}{l}\text { Poorly sorted, } \\
\text { subrounded to subangular, } \\
\text { very fine grained sand to silt with shells }\end{array}$ & Shell hash \\
\hline $\begin{array}{l}\text { Oyster bioherm } \\
\text { (O) }\end{array}$ & $\begin{array}{l}\text { Medium dark } \\
\text { gray; dark gray }\end{array}$ & $\begin{array}{c}\text { Very poorly sorted, } \\
\text { subrounded to subangular, } \\
\text { large oyster pieces with very fine grained } \\
\text { sand to silt matrix }\end{array}$ & Large articulated oyster shells \\
\hline $\begin{array}{l}\text { Mud } \\
\text { (M) }\end{array}$ & $\begin{array}{c}\text { Very dark } \\
\text { grayish brown }\end{array}$ & $\begin{array}{l}\text { Well to moderately sorted, } \\
\text { silt }\end{array}$ & $\begin{array}{c}\text { Roots and some woody debris } \\
\text { common; rare, large }(\sim 2 \mathrm{~cm}) \\
\text { burrows }\end{array}$ \\
\hline $\begin{array}{l}\text { Slightly gravely } \\
\text { muddy Sand } \\
(\operatorname{sgmS})\end{array}$ & $\begin{array}{l}\text { Dark gray; } \\
\text { light gray }\end{array}$ & $\begin{array}{c}\text { Moderately sorted } \\
\text { slightly very fine gravelly very coarse silty } \\
\text { fine sand }\end{array}$ & Bioturbated \\
\hline $\begin{array}{l}\text { Slightly gravely } \\
\text { sand } \\
(\mathrm{sgS})\end{array}$ & $\begin{array}{l}\text { Dark Gray; } \\
\text { Light Gray }\end{array}$ & $\begin{array}{l}\text { Poorly to moderately sorted, } \\
\text { slightly gravelly fine sand }\end{array}$ & $\begin{array}{l}\text { Roots (mm scale) with } \\
\text { infrequent larger roots (cm } \\
\text { scale) }\end{array}$ \\
\hline
\end{tabular}

The foraminiferal data (Table 5) indicate that there are three assemblages based

primarily on salinity: purely calcareous foraminifera (high brackish; salinity of 25-35),

purely agglutinated foraminifera (low brackish; salinity of $<10$ ) and an assemblage that is a mixture of calcareous and agglutinated foraminifera (mid-brackish; salinity of 10-25).

The low brackish assemblage contains eight species and is primarily comprised of Ammotium salsum (46.5\%), Genus A sp. A [organic] (26.4\%) and Ammobaculites crassus 
$(23.4 \%)$. These taxa are typical of modern low brackish estuarine conditions in Currituck, Albemarle, and Pamlico Sounds (Grossman and Benson, 1967; Abbene et al., 2006;

Vance et al., 2006) (Table 5). The mid-brackish assemblage contains 11 species and is primarily comprised of Ammonia parkinsoniana (26.7\%), Ammotium salsum (25.0\%), and Genus A sp. A [organic] (13.5\%). Similar assemblages inhabit mid-brackish estuarine environments in North Carolina and other coastal estuaries (Grossman and Benson, 1967; Culver and Buzas, 1980; Vance et al., 2006; Abbene et al. 2006) (Table 5). The third assemblage contains seven species and is primarily comprised of the calcareous taxa Elphidium excavatum (50.0\%), Ammonia parkinsoniana (31.4\%) and Haynesina germanica (7.8\%). Similar assemblages characterize high brackish estuaries (Grossman and Benson, 1967; Culver and Buzas, 1980; Abbene et al., 2006; Culver et al. 2008) (Table 5). Raw census data are presented in Table 6.

Table 5: Mean percentage of foraminiferal species in three salinity-related estuarine assemblages. The three most common species in each assemblage are in bold text.

\begin{tabular}{lccc}
\hline Species & Low Brackish & Mid Brackish & High Brackish \\
\hline Ammobaculites crassus & $\mathbf{2 3 . 4 \%}$ & $10.1 \%$ & \\
\hline Ammonia parkinsoniana & & $\mathbf{2 6 . 7 \%}$ & $\mathbf{3 1 . 4 \%}$ \\
\hline Ammotium salsum & $\mathbf{4 6 . 5 \%}$ & $\mathbf{2 5 . 0 \%}$ & \\
\hline Deuterammina ochracea & $2.8 \%$ & & \\
\hline Elphidium excavatum & & $6.2 \%$ & $\mathbf{5 0 . 0} \%$ \\
\hline Elphidium galvestonense & & $6.1 \%$ & $3.0 \%$ \\
\hline Elphidium gunteri & & $2.4 \%$ & $3.4 \%$ \\
\hline Elphidium transluscens & & $0.3 \%$ & $4.1 \%$ \\
\hline Genus A sp. A [organic] & $\mathbf{2 6 . 4 \%}$ & $\mathbf{1 3 . 5 \%}$ \\
\hline Hanzawaia strattoni & & $2.0 \%$ \\
\hline Haynesina germanica & $6.3 \%$ \\
\hline Indeterminate agglutinated & $0.1 \%$ & $\mathbf{7 . 8 \%}$ \\
\hline Jadammina macrescens & & \\
\hline Miliammina fusca & $0.03 \%$ & \\
\hline Polysaccammina ipohalina & $0.1 \%$ & \\
\hline Trochammina inflata & & \\
\hline
\end{tabular}


Table 6: Foraminiferal census data for surface (SS) and vibracore (VC) samples from Currituck Sound, NC. Surface samples were taken at same location as similarly numbered vibracores.

\begin{tabular}{|c|c|c|c|c|c|c|c|c|c|c|c|c|c|c|c|c|c|c|c|c|c|c|c|}
\hline Sample & $\overline{\tilde{n}}$ & $\begin{array}{l}\tilde{\delta} \\
\dot{J} \\
\text { İ } \\
\text { J } \\
>\end{array}$ & 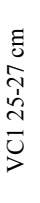 & 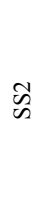 & 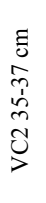 & 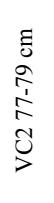 & 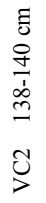 & 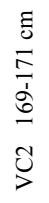 & 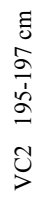 & $\tilde{n}$ & 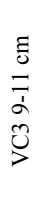 & 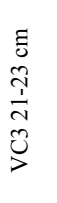 & 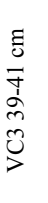 & 芯 & 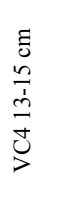 & 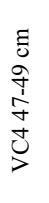 & 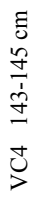 & $n$ & 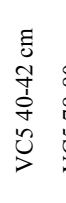 & 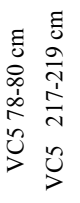 & ஜ & $\begin{array}{l}\tilde{\Xi} \\
0 \\
0 \\
0 \\
\infty \\
0 \\
0 \\
0 \\
>\end{array}$ & $\begin{array}{l}\tilde{\Xi} \\
0 \\
0 \\
0 \\
\dot{1} \\
0 \\
0 \\
0 \\
>\end{array}$ \\
\hline $\begin{array}{c}\text { Ammobaculites } \\
\text { crassus }\end{array}$ & 17 & 35 & & 38 & 60 & 9 & & & & 27 & & 3 & 10 & 19 & 24 & & & 42 & 7 & 8 & 39 & 17 & 16 \\
\hline $\begin{array}{c}\text { Ammonia } \\
\text { parkinsoniana }\end{array}$ & & & & & 2 & & & 41 & 37 & & & & 3 & & & 50 & 4 & & & & & & \\
\hline $\begin{array}{l}\text { Ammotium } \\
\text { salsum }\end{array}$ & 98 & 78 & 2 & 74 & 39 & 35 & & & & 75 & 4 & 112 & 25 & 75 & 45 & 4 & & 66 & 25 & 17 & 92 & 64 & 80 \\
\hline \multicolumn{24}{|l|}{$\begin{array}{l}\text { Deuterammina } \\
\text { ochracea }\end{array}$} \\
\hline $\begin{array}{l}\text { Elphidium } \\
\text { excavatum }\end{array}$ & & & & & & & & 40 & 40 & & 1 & & 1 & & & 23 & 5 & & & & & & \\
\hline $\begin{array}{c}\text { Elphidium } \\
\text { galvestonense }\end{array}$ & & & & & & & 1 & 2 & & & & & 2 & & & 4 & 1 & & & & & & \\
\hline Elphidium gunteri & & & & & & & & 7 & 7 & & & & & & & 18 & & & & & & & \\
\hline $\begin{array}{c}\text { Elphidium } \\
\text { transluscens }\end{array}$ & & & & & & & & 7 & 8 & & & & & & & 3 & & & & & & & \\
\hline $\begin{array}{l}\text { Genus A sp. A } \\
\text { [organic] }\end{array}$ & & & 2 & 1 & 4 & 65 & 1 & & 1 & & 1 & 1 & 3 & & 37 & & & & 51 & 1 & & 32 & 4 \\
\hline $\begin{array}{l}\text { Hanzawaia } \\
\text { strattoni }\end{array}$ & & & 1 & & & & & & & & & & & & & & & & & & & & \\
\hline $\begin{array}{l}\text { Haynesina } \\
\text { germanica }\end{array}$ & & & & & & & 1 & 15 & 6 & & & & 1 & & & 12 & & & & & & & \\
\hline $\begin{array}{l}\text { Indeterminate } \\
\text { agglutinated }\end{array}$ & & & & & & & & & & 1 & & & & & & & & & 1 & & & & \\
\hline \multicolumn{24}{|l|}{$\begin{array}{l}\text { Jadammina } \\
\text { macrescens }\end{array}$} \\
\hline Miliammina fusca & & & & 1 & & & & & & & & & & & & & & & & & & & \\
\hline $\begin{array}{l}\text { Polysaccammina } \\
\text { ipohalina }\end{array}$ & & 2 & & & & 1 & & & & & & & & & & & & & & & & & \\
\hline $\begin{array}{l}\text { Trochammina } \\
\text { inflata }\end{array}$ & & & & & & & & & & & & & & & & & & & & & & & \\
\hline
\end{tabular}




\section{Table 6 (continued)}

\begin{tabular}{|c|c|c|c|c|c|c|c|c|c|c|c|c|c|c|c|c|c|c|c|c|c|c|}
\hline Sample & $\hat{\tilde{n}}$ & 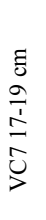 & $\begin{array}{l}\infty \\
\infty \\
\infty\end{array}$ & 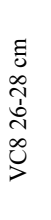 & $\begin{array}{l}\tilde{a} \\
\hat{\alpha} \\
\hat{1} \\
\alpha \\
\infty \\
0 \\
>\end{array}$ & $\begin{array}{l}5 \\
0 \\
0 \\
0 \\
1 \\
0 \\
0 \\
\infty \\
0 \\
>\end{array}$ & 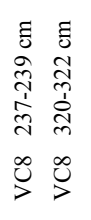 & के & 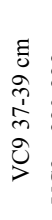 & 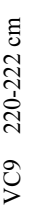 & $\frac{\circ}{\sqrt[n]{n}}$ & $\begin{array}{ll} & 0 \\
0 & 0 \\
0 & 0 \\
0 & 0 \\
0 & 0 \\
0 & 0 \\
0 & 0 \\
0 & 0 \\
> & >\end{array}$ & $\overrightarrow{\bar{v}}$ & $\begin{array}{l}a \\
0 \\
0 \\
i \\
i \\
i n \\
\bar{u} \\
0 \\
>\end{array}$ & 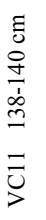 & $\frac{N}{\tilde{n}}$ & 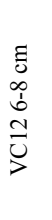 & 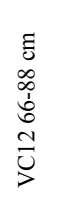 & 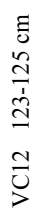 & $\frac{m}{n}$ & 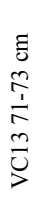 & 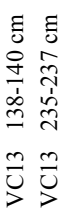 \\
\hline $\begin{array}{c}\text { Ammobaculites } \\
\text { crassus }\end{array}$ & 28 & & 25 & 11 & 1 & & & 56 & 2 & 1 & 68 & & 68 & & & 53 & & 34 & & 74 & 49 & \\
\hline $\begin{array}{c}\text { Ammonia } \\
\text { parkinsoniana }\end{array}$ & & 6 & & & & 19 & & & & & & & & & 23 & & & & 40 & & & 2 \\
\hline Ammotium salsum & 94 & & 121 & 72 & 9 & & & 67 & & 2 & 62 & & 74 & 2 & & 104 & & 33 & 7 & 50 & 6 & \\
\hline $\begin{array}{l}\text { Deuterammina } \\
\text { ochracea }\end{array}$ & & & & & & & 1 & & & & & & & & & & & & & & & \\
\hline $\begin{array}{l}\text { Elphidium } \\
\text { excavatum }\end{array}$ & & & & & & 97 & & & & & & & & & 43 & & & & 31 & & & \\
\hline $\begin{array}{l}\text { Elphidium } \\
\text { galvestonense }\end{array}$ & & & & & & 3 & & & & & & & & & 1 & & & & 28 & & & \\
\hline Elphidium gunteri & & & & & & 5 & & & & & & & & & & & & & 11 & & & \\
\hline $\begin{array}{l}\text { Elphidium } \\
\text { transluscens }\end{array}$ & & & & & & 5 & & & & & & & & & 2 & & & & & & & \\
\hline $\begin{array}{l}\text { Genus A sp. A } \\
\text { [organic] }\end{array}$ & & & & 33 & & 1 & 4 & & & & & 22 & & 54 & & & 2 & 28 & & & 31 & 3 \\
\hline \multicolumn{23}{|l|}{ Hanzawaia strattoni } \\
\hline $\begin{array}{l}\text { Haynesina } \\
\text { germanica }\end{array}$ & & & & & & 11 & & & & & & & & & 9 & & & & 24 & & & \\
\hline \multicolumn{23}{|l|}{$\begin{array}{l}\text { Indeterminate } \\
\text { agglutinated }\end{array}$} \\
\hline $\begin{array}{l}\text { Jadammina } \\
\text { macrescens }\end{array}$ & & 1 & & & & & & & & & & & & & & & & & & & & \\
\hline \multicolumn{23}{|l|}{ Miliammina fusca } \\
\hline \multicolumn{23}{|l|}{$\begin{array}{l}\text { Polysaccammina } \\
\text { ipohalina }\end{array}$} \\
\hline Trochammina inflata & & & & & & & & & & & & & & & & & & & & & & 1 \\
\hline
\end{tabular}

$\begin{array}{lllllllllllllllllllllllllll}\text { Total Foraminifera } & 122 & 7 & 146 & 116 & 10 & 141 & 4 & 1 & 123 & 2 & 3 & 130 & 2 & 2 & 142 & 56 & 78 & 157 & 2 & 95 & 141 & 124 & 86 & 4 & 2\end{array}$ 
Transects were create from the cores, one running from north to south (Figure 7) throughout the sound and three running from west to east and intersecting the north-south transect (Figures 8A and B). All cores in Figure 7 show a clean sand unit at the bottom with an overall fining- and then coarsening-upward sequence. Five units are recognized, Units I and Ib though IV.

The bottom sand unit (Unit I) is Pleistocene in age, based on the OSL age estimate of $33.7 \mathrm{ka}$ in core $\mathrm{VC} 4$. The sand is barren of foraminifera, as is modern beach sand in North Carolina (Abbene et al., 2006; Vance et al., 2006; Culver et al., 2006, 2008) and is interpreted to be lower shoreface sand associated with the Pleistocene paleoshoreline to the west (Mallinson et al., 2008; Culver et al., 2011). One specimen of the very delicate Deuterammina ochracea in VC8 is considered to be a contaminant. The bottom sand unit (Unit Ib) in cores 7, 9, 12 and 13 is interpreted to be an intertidal to a shallow sub-tidal sand flat incised by $\mathrm{H}_{\mathrm{SF}}$; two specimens of Ammonia parkinsoniana from the bottom of the sand unit in CUR11 VC 13 (Figure 7) indicate a probable mid- to high brackish environment. The likely sand source is the ridges in the Kitty Hawk area (Figure 1). The OSL age estimate for Unit Ib in VC 12 is $4.5 \mathrm{ka}$.

The ca. $1-5 \mathrm{~m}$ thick slightly muddy sand to mud (Unit II) above the Holocene/Pleistocene contact (H0) displays rooted horizons and lacks foraminifera. The roots within these units are thick ( $2 \mathrm{~cm}$ scale) and woody. They were used for two radiocarbon age estimates close to the bottom and top of Unit II; these age estimates are 4080-3890 cal y BP and $2950-2790$ cal y BP, respectively. Unit II is interpreted as fresh water swamp forest due to the presence of large roots and the complete lack of foraminifera. 


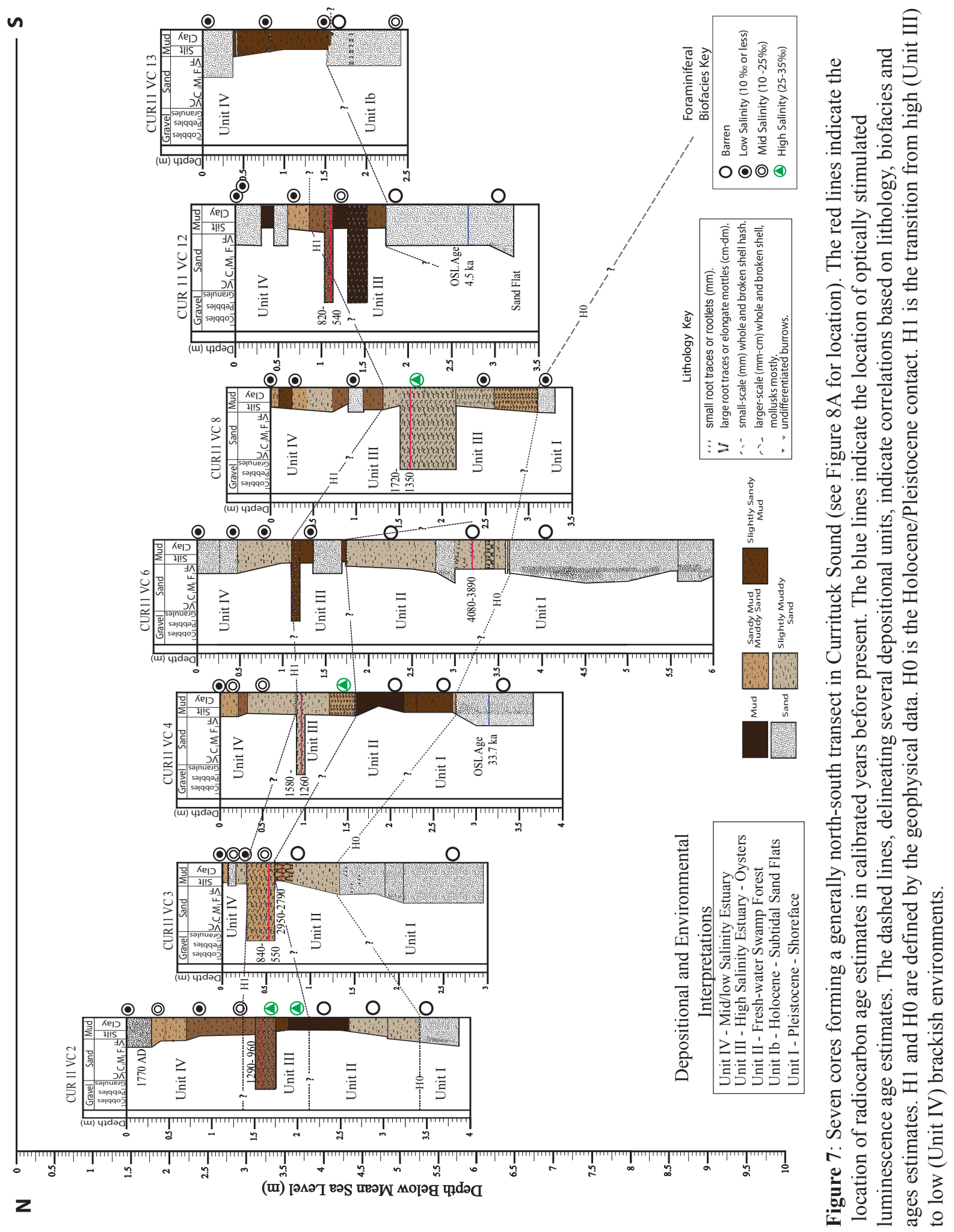


Foraminiferal

Biofacies Key

B Barren

(2) Low Salinity (10\% or less)

(2) Mid Salinity (10-25\%)

(2) High Salinity (25-35\%)

\section{Lithology}

« small root traces or rootlets ( $\mathrm{mm})$.

\$. large root traces or elongate mottles (cm-dm).

... small-scale $(\mathrm{mm})$ whole and broken shell hash.

larger-scale $(\mathrm{mm}-\mathrm{cm})$ whole and broken

- shell, mollusks mostly.

$v \quad v$ undifferentiated burrows.
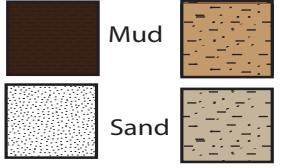

Sandy Mud Muddy Sand

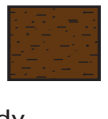

Slightly Sandy Mud

Sand

Slightly Muddy

Sand

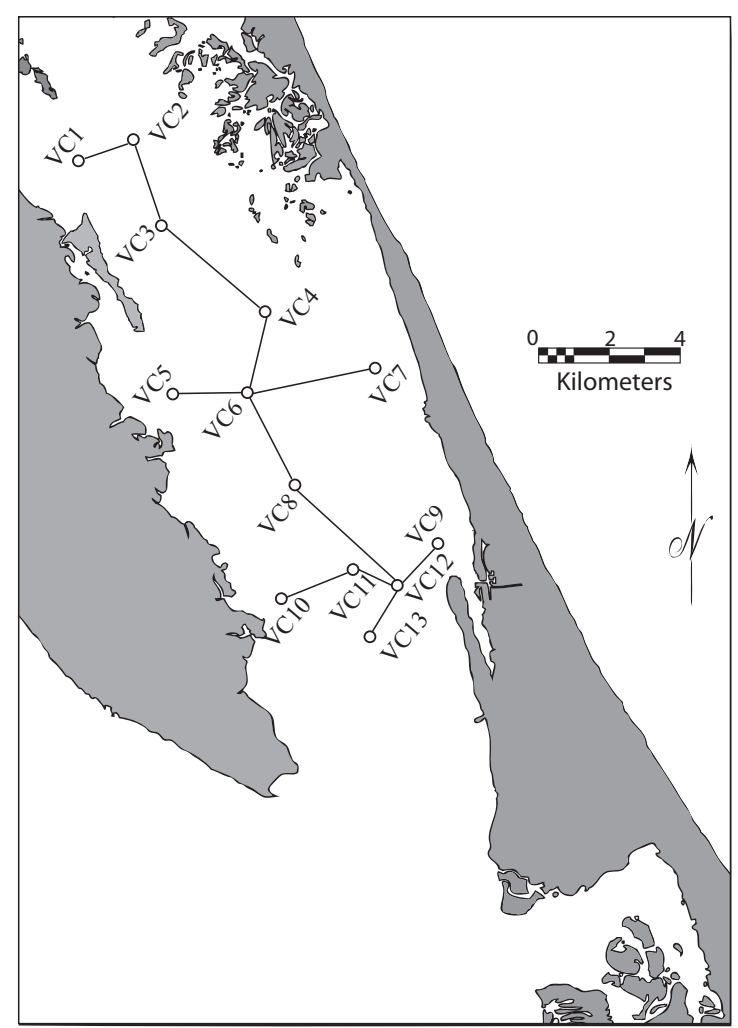

W

0 韦

.

E

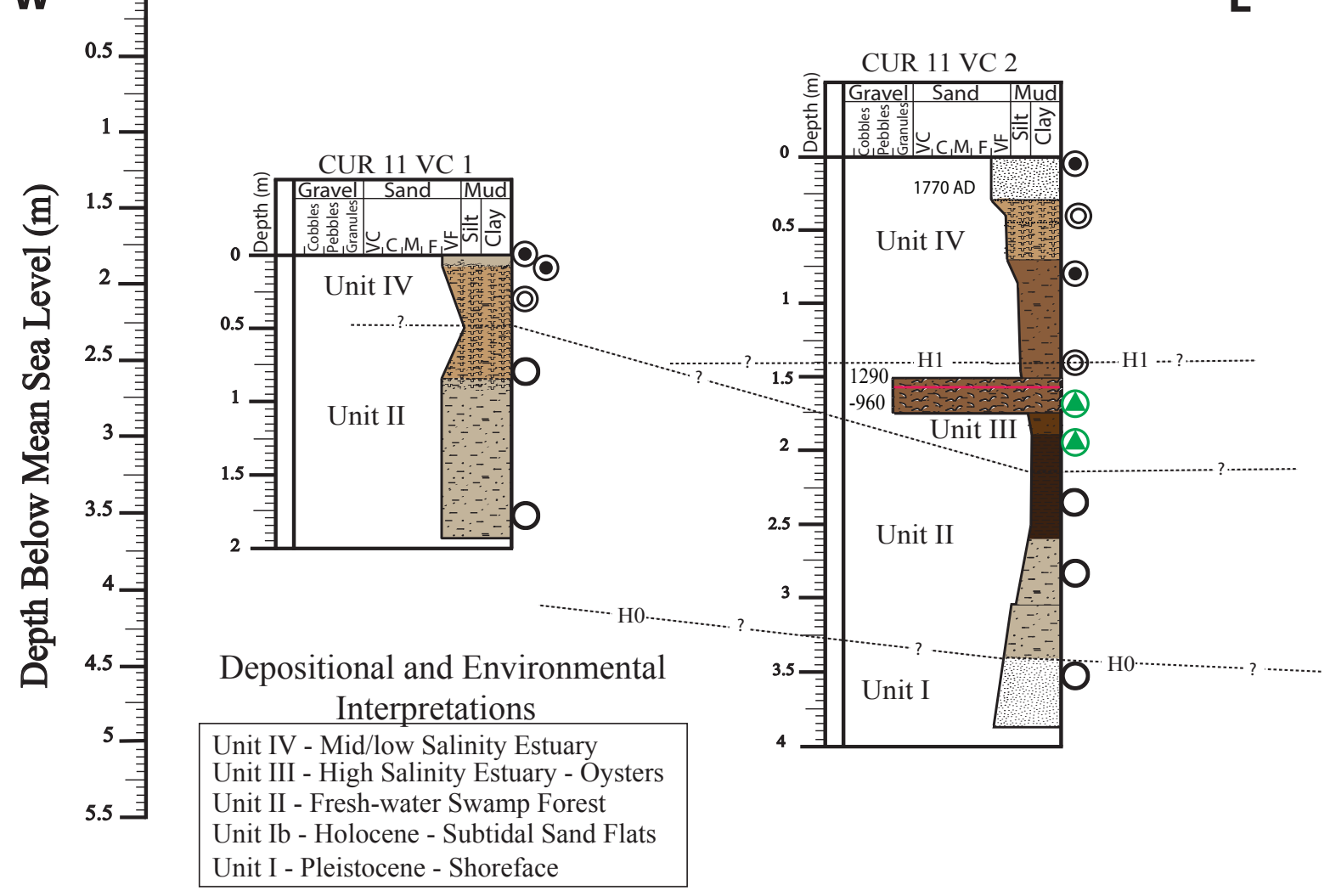

Figure 8A 

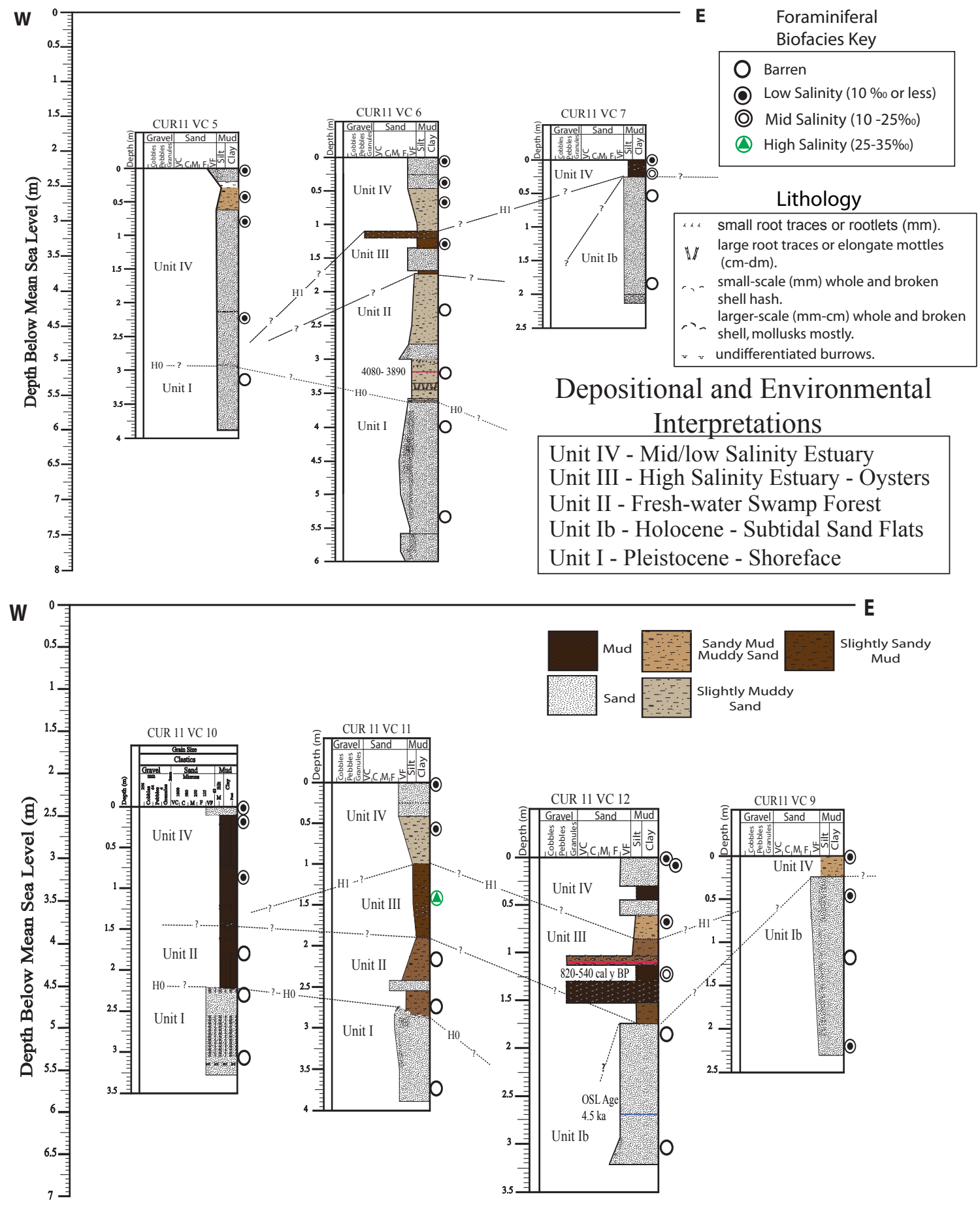

Figure 8B: Figures $8 \mathrm{~A}$ and $8 \mathrm{~B}$ are three east west transects of cores in Currituck Sound. The red lines indicate the location of radiocarbon age estimates in calibrated in years before present. The blue lines indicate optically stimulated luminescence age estimates. The dashed lines, delineating several depositional units, indicate correlations based on lithology, biofacies, and age. $\mathrm{H} 1$ and $\mathrm{H} 0$ correlate to the geophysics. H1 is the transition from high (Unit III) to low (Unit IV) brackish environments. $\mathrm{H} 0$ is the Holocene/Pleistocene contact. The transects show differences in lithology between the northern and southern ends of the Sound as well as a difference from east to west throughout the Sound. 
Unit III contains foraminiferal assemblages dominated by Elphidium excavatum and Ammonia parkinsoniana indicating high (25-35) and mid (10-25) brackish environmental conditions (Grossman and Benson, 1967; Vance et al., 2006; Abbene et al., 2006; Culver et al., 1996, 2007). High brackish conditions are also indicated by the presence of oyster bioherms throughout the Sound. Age estimates on the oyster reefs range from a maximum of $1700 \mathrm{cal}$ y $\mathrm{BP}$ to a minimum of $500 \mathrm{cal}$ y $\mathrm{BP}$. Two oyster reef building episodes are indicated. The older episode was widespread throughout the Sound and lasted from roughly $1700 \mathrm{cal}$ years BP to $900 \mathrm{cal}$ years BP. The younger, less widespread episode occurred around 800 to 500 cal years BP.

A mid- to low brackish (Unit IV) estuarine unit ranges in thickness from 0.25 to $2.95 \mathrm{~m}$ and varies in composition from mud to sand. Unit IV is generally mid-brackish lower in the section and becomes low brackish upward. Foraminiferal assemblages are dominated by Ammotium salsum, Ammobaculites crassus, and Ammonia parkinsoniana, typical of low salinity, back-barrier estuaries on the North American east coast (e.g., Grossman and Benson, 1967; Culver and Buzas, 1980; Culver et al., 1996, 2006, 2007; Woo et al., 1997; Abbene et al., 2006; Vance et al., 2006).

\section{i. Hydrodynamic Modeling}

Four paleoenvironmental maps (Figure 9) were created using the lithofacies, biofacies and radiocarbon and optically stimulated luminescence age estimates as well as the North Carolina sea-level curve (Horton et al., 2009) for the following time slices: $5000-3000$ cal y BP, $\sim 3000-1000$ cal y BP, $\sim 1000-500$ cal y BP and $<500$ cal y BP. The map drawn by White and deBry in 1590 supplemented these paleoenvironmental maps. Together they provide the basis for the model runs. The results are discussed below 
in the context of the geologic evolution of the Currituck Sound system. Current velocity measurements were produced for each core location during each model run; the results are given in Table 7. 

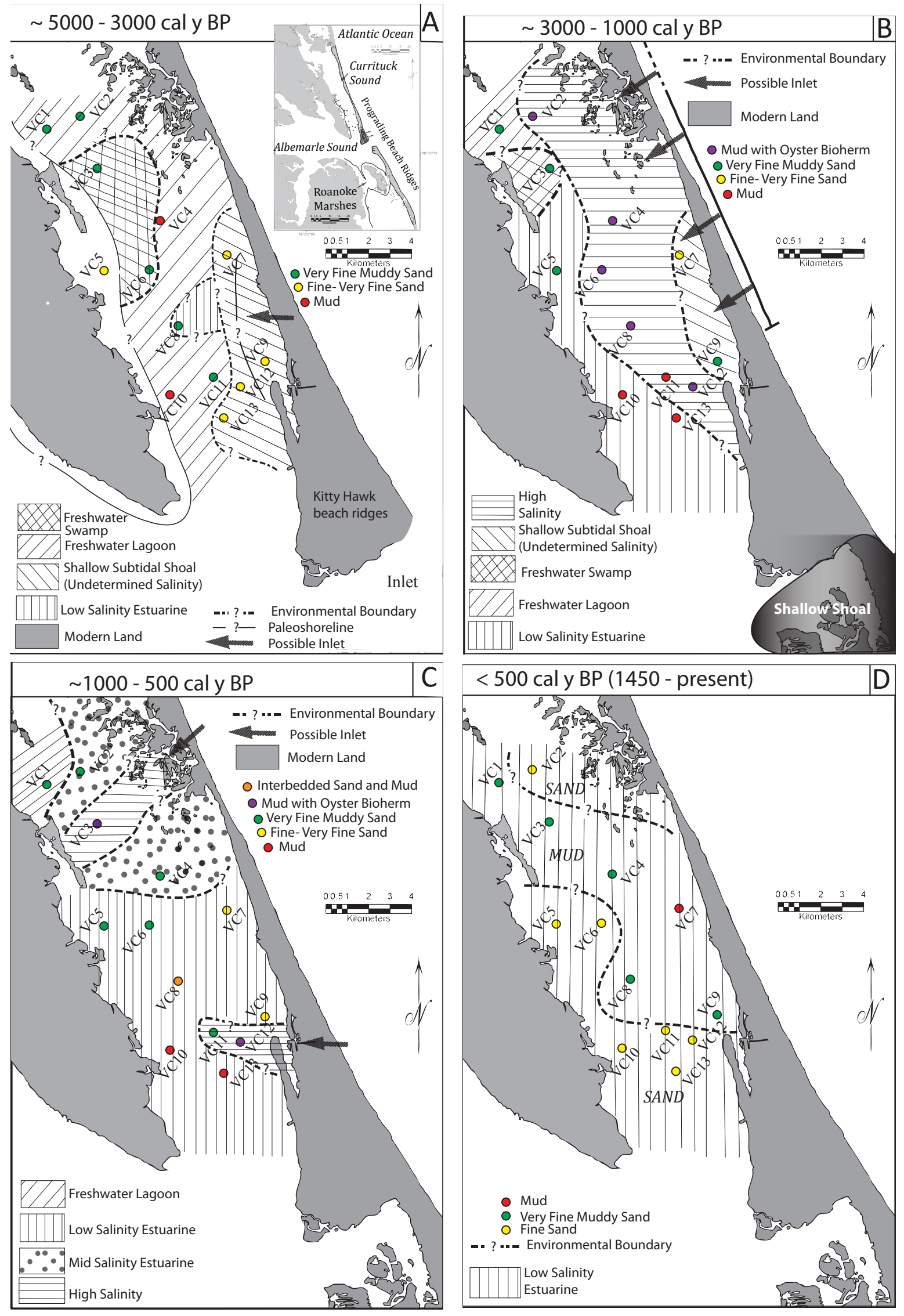
Figure 9: The evolution of Currituck Sound (interpreted from biofacies, lithofacies, and geochronologic data) for four time slices. The gray shaded land indicates the modern barrier island and mainland. A) 5000 - 3000 cal y BP: an inlet occurs just south of the modern Kitty Hawk beach ridges (Culver et al. 2008). A second inlet was possibly located adjacent to VC8. The Roanoke Marshes were present at this time, separating the Albemarle Sound from Pamlico Sound. B) 3000 - 1000 cal y BP: several inlets were open between Caffey's Inlet and the Kitty Hawk beach ridges. Due to the number and location of the inlets the marine influence was highest at this time and most likely contributed to the extensive oyster bioherm building episodes of Unit III (Figures 5, 7 and 8). C) 1000 - 500 cal y BP: only one inlet was open at the northern end of the study area and had an impact on the salinity of the Sound until it closed in 1828 (Stick, 1958; Fisher, 1962) creating the transition from Unit III to Unit IV (Figures 7 and $8)$. D) $<500$ cal y BP (the modern scenario): There are no inlets and the salinity changes from mid- to low salinity over time (Unit IV) (Figure 7 and 8).

Table 7: Table of tidal amplitude and current speed measured at each vibracore location for each of the modeled scenarios.

\begin{tabular}{lccccccc} 
Run700 $\mathbf{5 0 0 0}-\mathbf{3 0 0 0}$ cal y BP & VC2 & VC3 & VC4 & VC6 & VC8 & VC11 & VC13 \\
\hline Tidal amplitude (m) & 0.25 & 0.25 & 0.26 & 0.26 & 0.25 & 0.27 & 0.28 \\
Current speed (RMS) (m/s) & 0.10 & 0.15 & 0.15 & 0.13 & 0.23 & 0.34 & 0.47 \\
Run400 $\mathbf{3 0 0 0 - 1 0 0 0 ~ c a l ~ y ~ B P ~}$ & & & & & & & \\
\hline Tidal amplitude (m) & 0.52 & 0.53 & 0.53 & 0.52 & 0.51 & 0.46 & 0.40 \\
Current speed (RMS) (m/s) & 0.19 & 0.10 & 0.21 & 0.14 & 0.28 & 0.42 & 0.49 \\
Run600 $\mathbf{1 0 0 0 - 5 0 0 ~ c a l ~ y ~ B P ~}$ & & & & & & & \\
\hline Tidal amplitude (m) & 0.32 & 0.27 & 0.24 & 0.24 & 0.23 & 0.22 & 0.20 \\
Current speed (RMS) (m/s) & 0.43 & 0.20 & 0.13 & 0.09 & 0.13 & 0.16 & 0.20 \\
Run300 1590 Map & & & & & & & \\
\hline Tidal amplitude (m) & 0.40 & 0.40 & 0.40 & 0.40 & 0.39 & 0.37 & 0.32 \\
Current speed (RMS) (m/s) & 0.27 & 0.18 & 0.08 & 0.10 & 0.22 & 0.40 & 0.44 \\
Run100< 500 cal y BP Modern & & & & & & & \\
\hline Tidal amplitude (m) & 0.10 & 0.10 & 0.10 & 0.10 & 0.09 & 0.09 & 0.09 \\
Current speed (RMS) (m/s) & 0.02 & 0.02 & 0.02 & 0.02 & 0.03 & 0.04 & 0.07
\end{tabular}




\section{Discussion}

Vibracores 2, 3, 4, 5, 6, 8, 10 and 11 penetrated Pleistocene sediments (Figures 7 and 8). The elevation of the Pleistocene surface generally decreases from the northern end of Currituck Sound near VC3 to the south (Figure 7). Based on the Horton et al. (2009) sea-level curve for North Carolina the Pleistocene surface began to flood at the southern end of the Sound between 5000 and 6000 years ago and was completely flooded when the paleotopographic high in the north was submerged around 4000 years ago.

\section{a. 5000-3000 cal y BP}

During the $\sim 5000-3000$ cal y BP time interval the shoreline transgressed rapidly to a position near VC12 and VC9. Seismic data reveal the position of the marine ravinement surface $\left(\mathrm{H}_{\mathrm{MRS}}\right.$; Figure 4$)$. Although the ocean shoreline was further west than present, the Sound was primarily a fresh water lagoon with a hardwood swamp forest perched on a paleotopographic high in the northern end (Figure 9A) based on the woody, rooted horizons found in cores VC3 and VC6 as well as the absence of foraminifera. The Kitty Hawk beach ridges were beginning their eastward progradation (Mallinson et al. 2008; Culver et al. 2008). During this time interval Culver et al. (2008) showed the Roanoke Marshes likely extending from the mainland to Roanoke Island (Figures 1, 9A) creating a barrier that divided Albemarle Sound from Pamlico Sound (Cumming, 1958).

During this time interval (Figure 9A) a large inlet was open immediately to the south of the modern Kitty Hawk beach ridges (Riggs et al., 1992, 1995; Culver et al., 2008). This allowed for greater hydraulic connectivity between the ocean and Albemarle

Sound. By the end of the $\sim 5000$ to 3000 cal y BP interval, the inlet had been restricted 
by the growth of a baymouth sand shoal (Colington Shoals) reducing the marine influence on Albemarle Sound (Mallinson et al., 2005; Culver et al., 2008).

In the center of Currituck Sound is a single occurrence of a low brackish estuarine deposit (in VC8) indicating some hydraulic connection to higher brackish or marine water, either from Albemarle Sound or via a small inlet open in the vicinity of historic Trinity Inlet (Figure 1). An intertidal to shallow sub-tidal sand flat extends along the barrier island in eastern Currituck Sound (Figure 9A). Salinity information is lacking (the sand is barren of foraminifera) geophysical data, however, indicate tidal channels $\left(\mathrm{H}_{\mathrm{SF}}\right.$; Figures 4,5 ) with oyster bioherms at the center, most likely a result of Trinity Inlet being open at this time.

The Delft3D model run (Figure 10) suggests that having a large inlet open just south of Kitty Hawk, as suggested by Culver et al. (2008), has little effect on the tides and currents in Currituck Sound. Thus the inlet at the mouth of Albemarle Sound could have been quite large and the sediments and salinity levels in Currituck Sound could have remained largely unaffected. This also suggests that the source of the higher salinity water in the low salinity facies in VC8 a more proximal inlet, perhaps in the vicinity of historic Trinity Inlet (indicated by arrow in Figure 9A).

\section{b. $\sim 3000-1000$ cal y BP}

During the $\sim 3000-1000$ cal y BP interval, geologic data indicate that Currituck Sound was hydraulically connected to the ocean (Figure 9B). This is expressed by the presence of high salinity foraminifera and oyster reefs in vibracores $\mathrm{VC} 2, \mathrm{VC} 4, \mathrm{VC} 6$, VC8, and VC12. The prolific oyster reefs and highest salinity levels during this time interval suggest more than one inlet was open, all between historic Caffey's Inlet and 


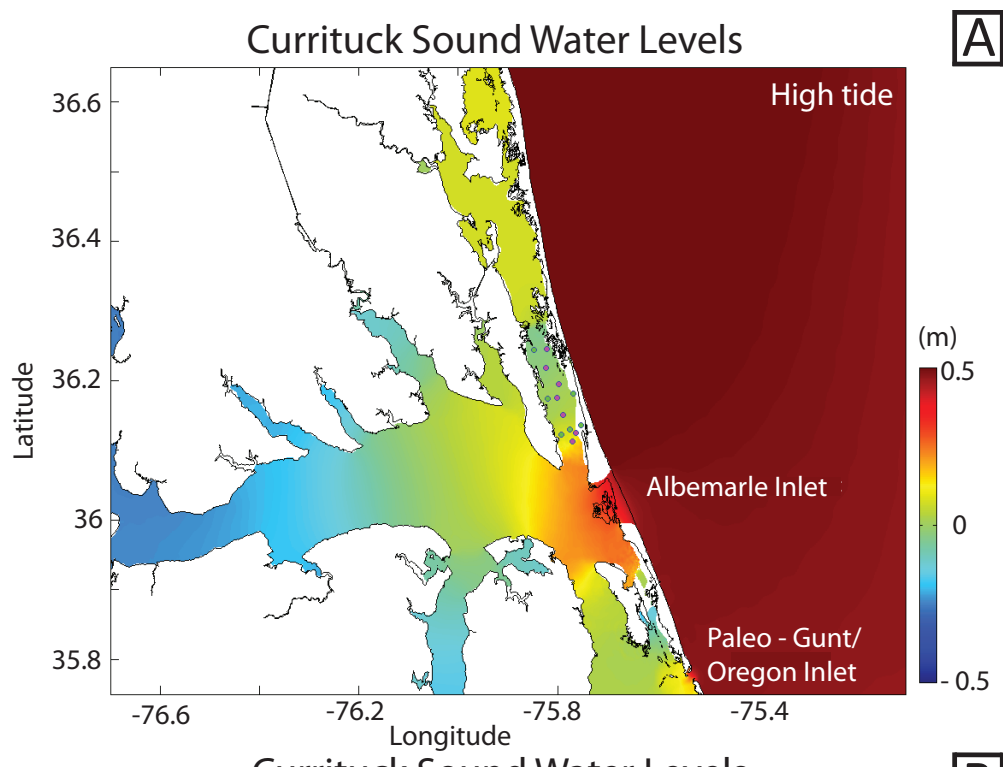

Currituck Sound Water Levels

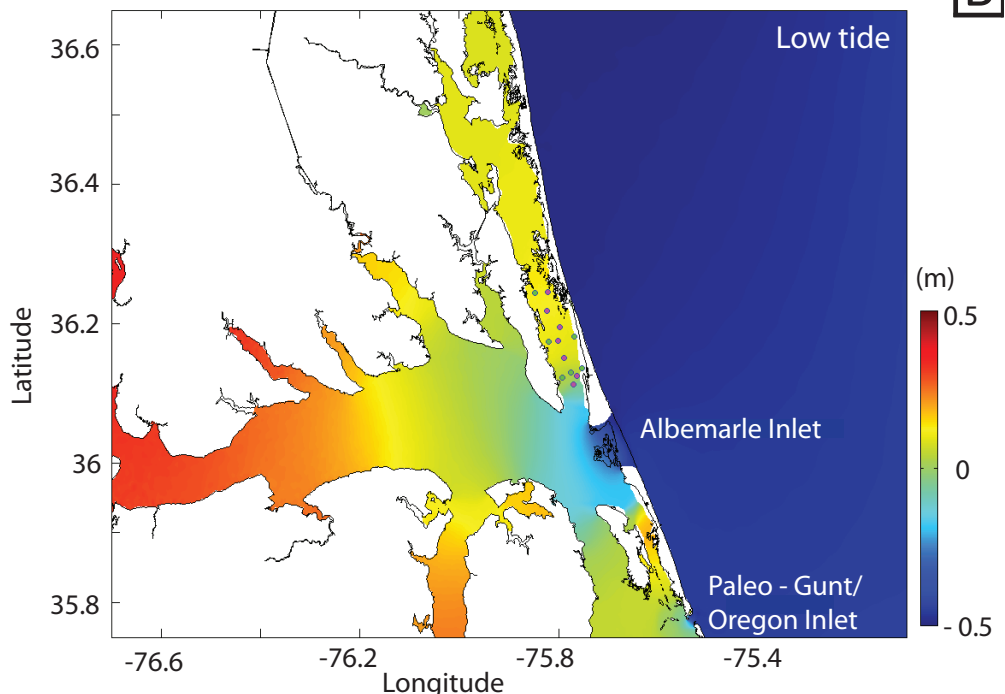

Currituck Sound Currents

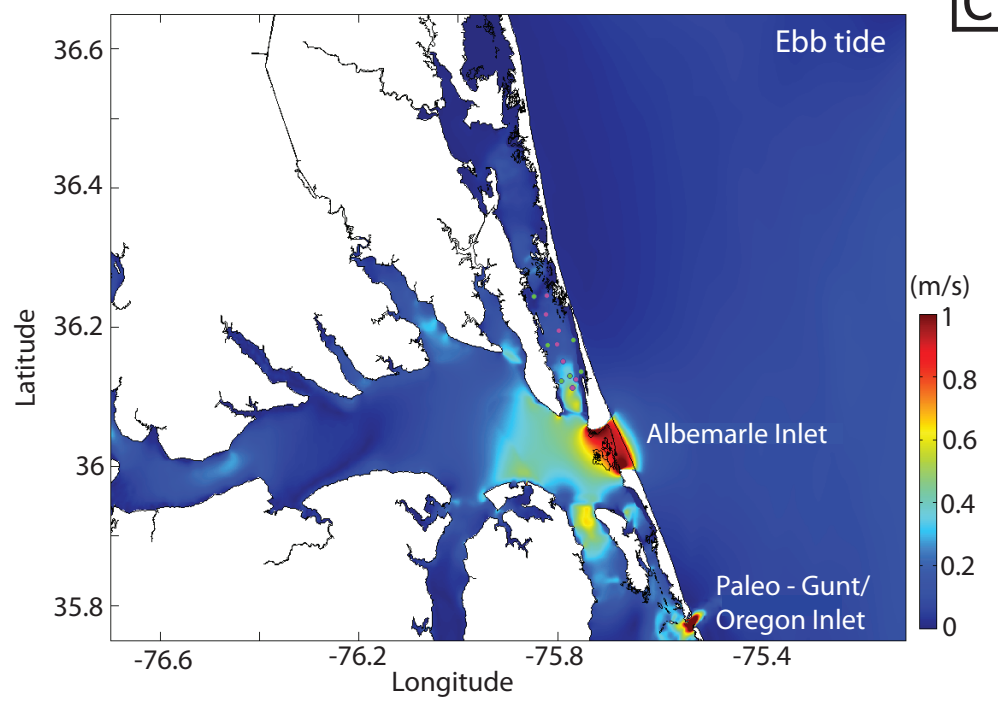

Figure 10: 5000 - 3000 cal y BP Delft3D model run with an inlet at the mouth of Albemarle Sound as indicated by Culver et al. (2008) and Figure 9A.

Location of vibracores indicated in southern Currituck Sound by dots. A) High tide in the ocean $(0.5 \mathrm{~m})$ and its effects on the estuarine system. A maximum of $0.25 \mathrm{~m}$ water level change is felt within Albemarle Sound and Currituck Sound remains largely unaffected. B) Low tide in the ocean $(-0.5 \mathrm{~m})$ and its effects on the estuarine system. Currituck Sound experiences a lag and exhibits slightly elevated water levels $(0.13 \mathrm{~m})$ at this time. C) Water current magnitude, with a maximum velocity of $1 \mathrm{~m} / \mathrm{s}$ directly in the inlet mouth and velocities up to $0.6 \mathrm{~m} / \mathrm{s}$ in Albemarle Sound. Currituck Sound experiences current velocities up to $0.6 \mathrm{~m} / \mathrm{s}$ in the southern end, near the location of vibracores VC 9 - VC 13. 
Kitty Hawk (Figure 1); for the purposes of this paper they will be called the Caffey's Inlet Complex. This created a high salinity estuary with significant marine influence in the east of the. The western sound was characterized by low salinity conditions and the deposits are primarily mud with some very find muddy sand. A small area of freshwater swamp still existed on the paleotopographic high to the northern end of the study area. The Delft3D model run (Figure 11) suggests that opening many inlets creates a $1 \mathrm{~m}$ tidal range in the southern end of Currituck Sound. Current velocities within the inlets reach up to $1 \mathrm{~m} / \mathrm{s}$ but are very localized while velocities up to $0.3 \mathrm{~m} / \mathrm{s}$ are associated with the areas directly adjacent to the inlets in the southern end of the Sound. However, high current velocities in the southern end of Currituck Sound seem improbable during this time interval as suggested by the occurrence of mud that dominates this area (Figure 9B). It is possible that the number and size of inlets opened during this model run is inaccurate. It is also possible that the discrepancy results from the distance of the barrier islands and inlet from the core sites. The model was run with the modern geographic configuration of the system but it is likely that the barriers were further offshore during this time period such that the core sites record deposits that are distal from the inlets and, therefore, finer.

\section{c. $\sim \mathbf{1 0 0 0}-\mathbf{5 0 0}$ cal y BP}

The $\sim 1000-500$ cal y BP time interval (Figure 9C) is characterized by two inlets, Caffey's Inlet in the north and Trinity Inlet in the south. This reduction from several inlets during the previous time interval to two results in a contraction of high salinity estuarine conditions. The sediments and foraminiferal assemblages indicate an inlet in the northern end of the study area in the general location of Caffey's Inlet (Figures 1, 9C). A 


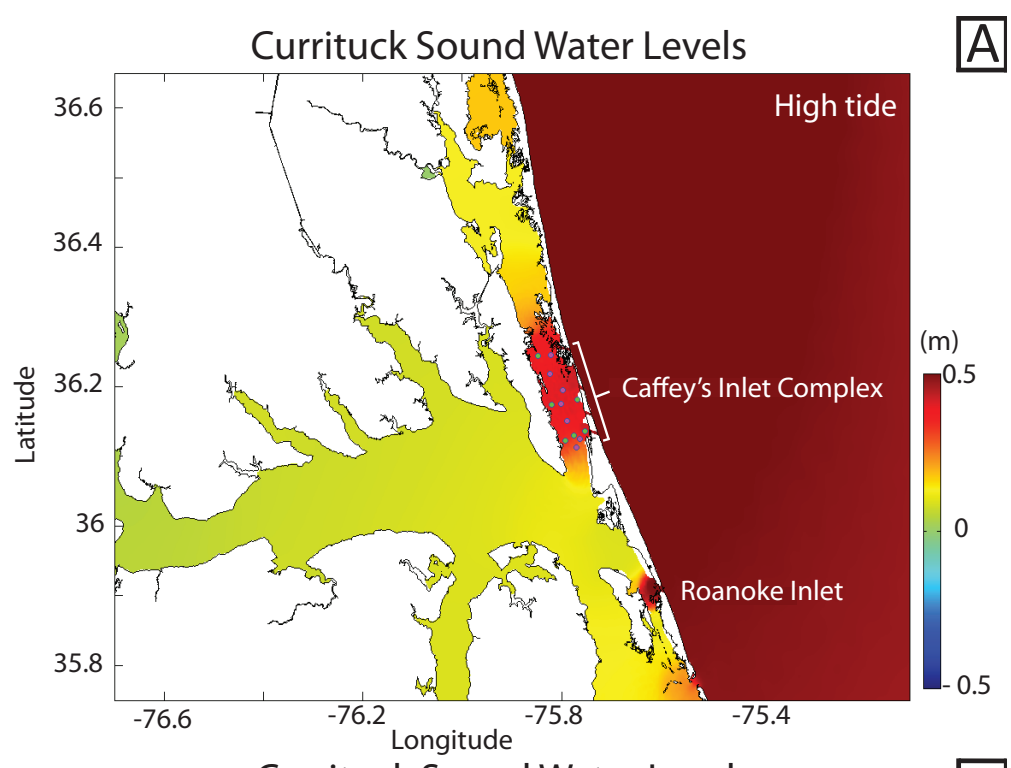

Currituck Sound Water Levels

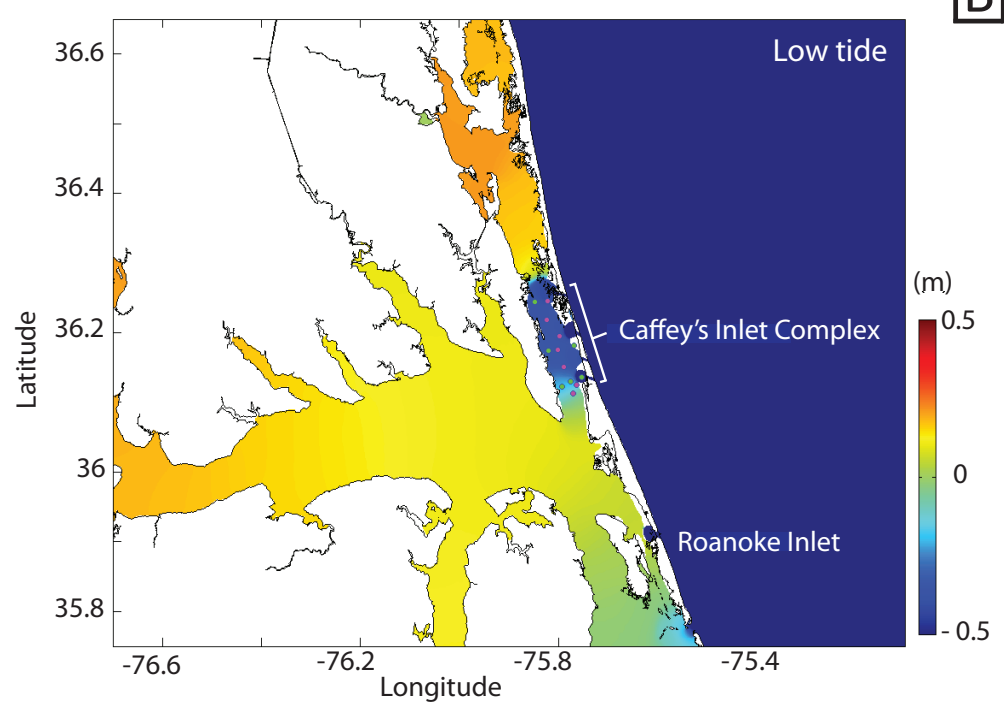

Currituck Sound Currents

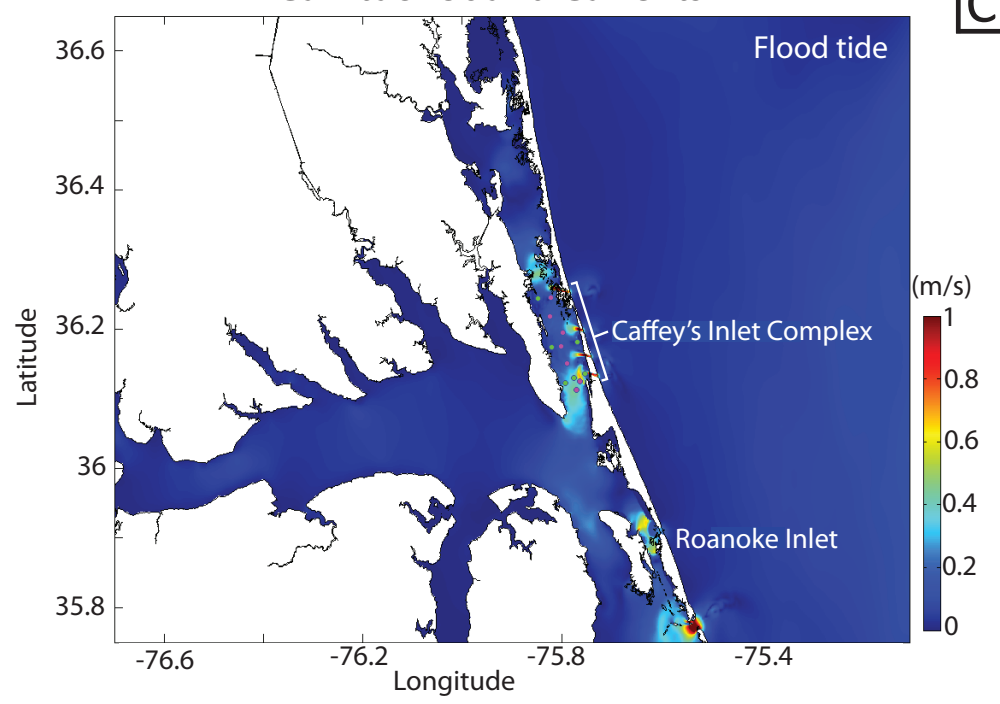

Figure 11: 3000 - 1000 cal y BP Delft3D model run with Caffey's Inlet complex open as indicated by Figure 9B; Roanoke Inlet is also open. A) High tide in the ocean $(0.5 \mathrm{~m})$ and its effects on the estuarine system. A maximum of $0.45 \mathrm{~m}$ water level change is felt within Currituck Sound. B) Low tide in the ocean $(-0.5 \mathrm{~m})$ and its effects on the estuarine system. Southern Currituck Sound exhibits a -0.45 $\mathrm{m}$ water level at this time and a maximum tidal range of about 1 m. C) Water current magnitude, with a maximum velocity of 1 $\mathrm{m} / \mathrm{s}$ directly in the inlet mouths and velocities from $0.3 \mathrm{~m} / \mathrm{s}$ to 0.7 $\mathrm{m} / \mathrm{s}$ within Currituck Sound in localized areas surrounding inlets. 
small area of high salinity conditions in southern Currituck Sound (Figure 9C) suggests that historic Trinity Inlet (Figure 1) was open during this time interval. The inlet scenario with Trinity and Caffey's Inlets open was not modeled. The modeled inlet scenario (Figure 12) with Roanoke and Caffey's Inlets open indicates that Roanoke Inlet is too far to the south to have an impact on Currituck Sound, thus confirming that Trinity Inlet was likely open during this time interval.

Current velocities within inlets are up to $1 \mathrm{~m} / \mathrm{s}$ with limited influence outside of their direct area; thus southern Currituck Sound was largely unaffected by strong current velocities during this time interval. The sediments recovered from the vibracores (Figure 9C) indicate mud and oyster bioherms within inlet channels with very fine muddy sands flanking channels.

\section{d. $<500$ (Modern Scenario)}

Sediments and foraminiferal assemblages (Figures 7, 8 and 9D) indicate, in low resolution, that southern Currituck Sound has had mid- to low- salinities throughout the past 500 years with a general trend to lower salinity over time. This reflects the historically documented closures of many inlets in the Outer Banks (Figure 1). Mallinson et al. (2011) suggested that inlet closure could be related to fewer storm impacts during the past 300 years. New Currituck Inlet closed around 200 years ago (Stick, 1958; Fisher, 1962) almost completely closing off Currituck Sound from any marine influence. The $<500$ cal y BP (modern) scenario indicates that southern Currituck Sound is entirely low salinity, although, some areas are sandier than others, perhaps reflecting the proximity of pre-existing sand deposits (Figure 9D). 


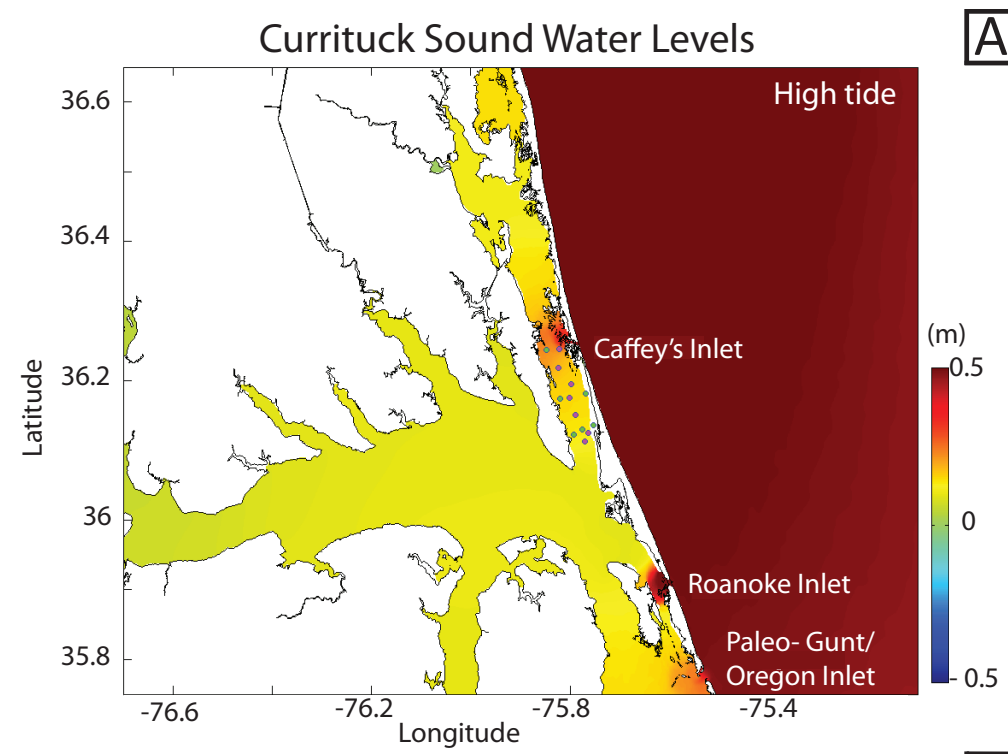

Currituck Sound Water Levels

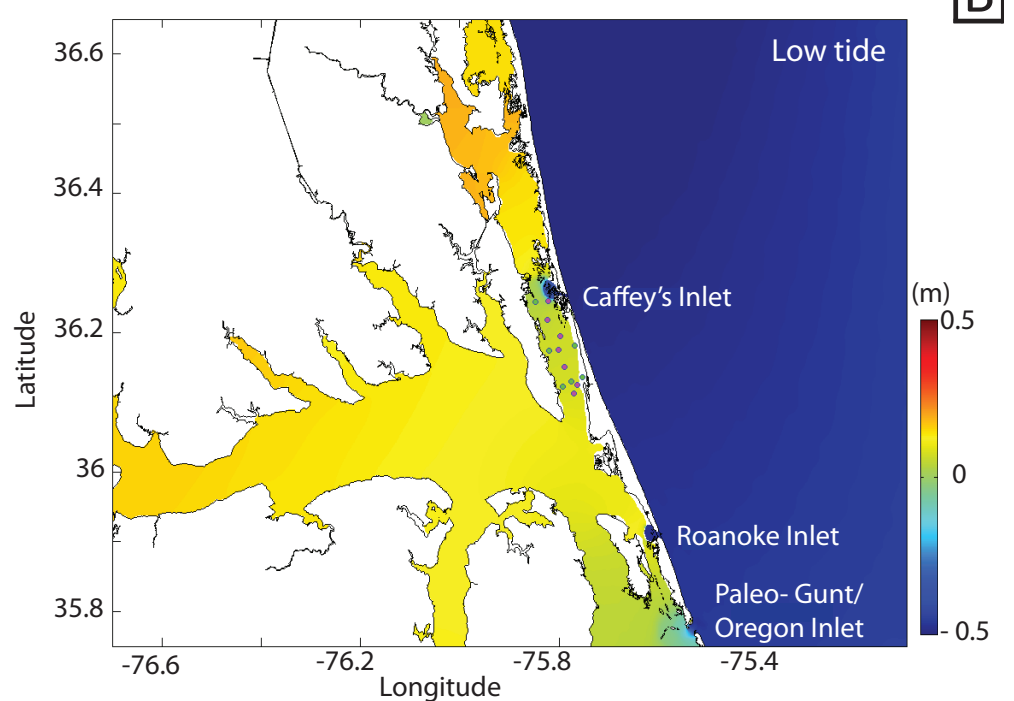

Currituck Sound Currents

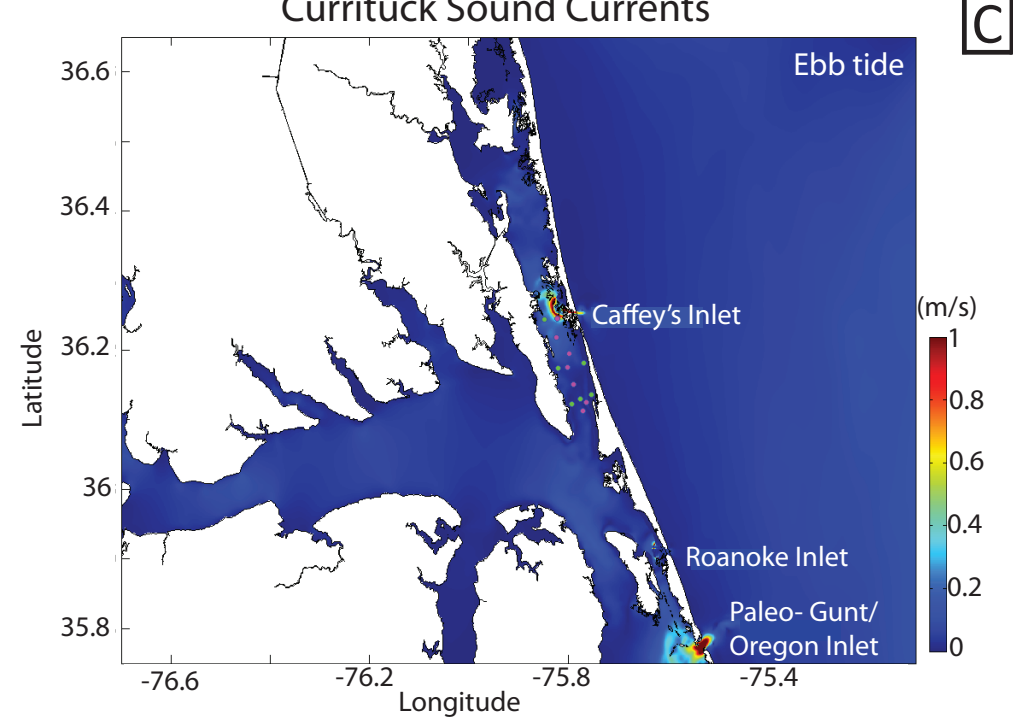

Figure 12: $1000-500$ cal y BP Delft3D model run with Caffey's Roanoke and paleo-Gunt/Oregon inlets open as indicated by Figure 9C. A) High tide in the ocean (0.5 $\mathrm{m})$ and its effects on the estuarine system. A maximum of $0.5 \mathrm{~m}$ of water level change is felt in the immediate area of the inlets while a $0.25 \mathrm{~m}$ water level change is felt within a wider area in Currituck Sound. A large part of Currituck Sound displays limited tidal influence with a water level near $0.01 \mathrm{~m} . \mathrm{B})$ Low tide in the ocean $(-0.5 \mathrm{~m})$ and its effects on the estuarine system. Currituck Sound experiences little change between high and low tide at this time interval; the water level remains at about $0.1 \mathrm{~m}$. C) Water current magnitude, with a maximum velocity of $1 \mathrm{~m} / \mathrm{s}$ directly in the inlet mouths but little influence within Currituck Sound beyond that. 

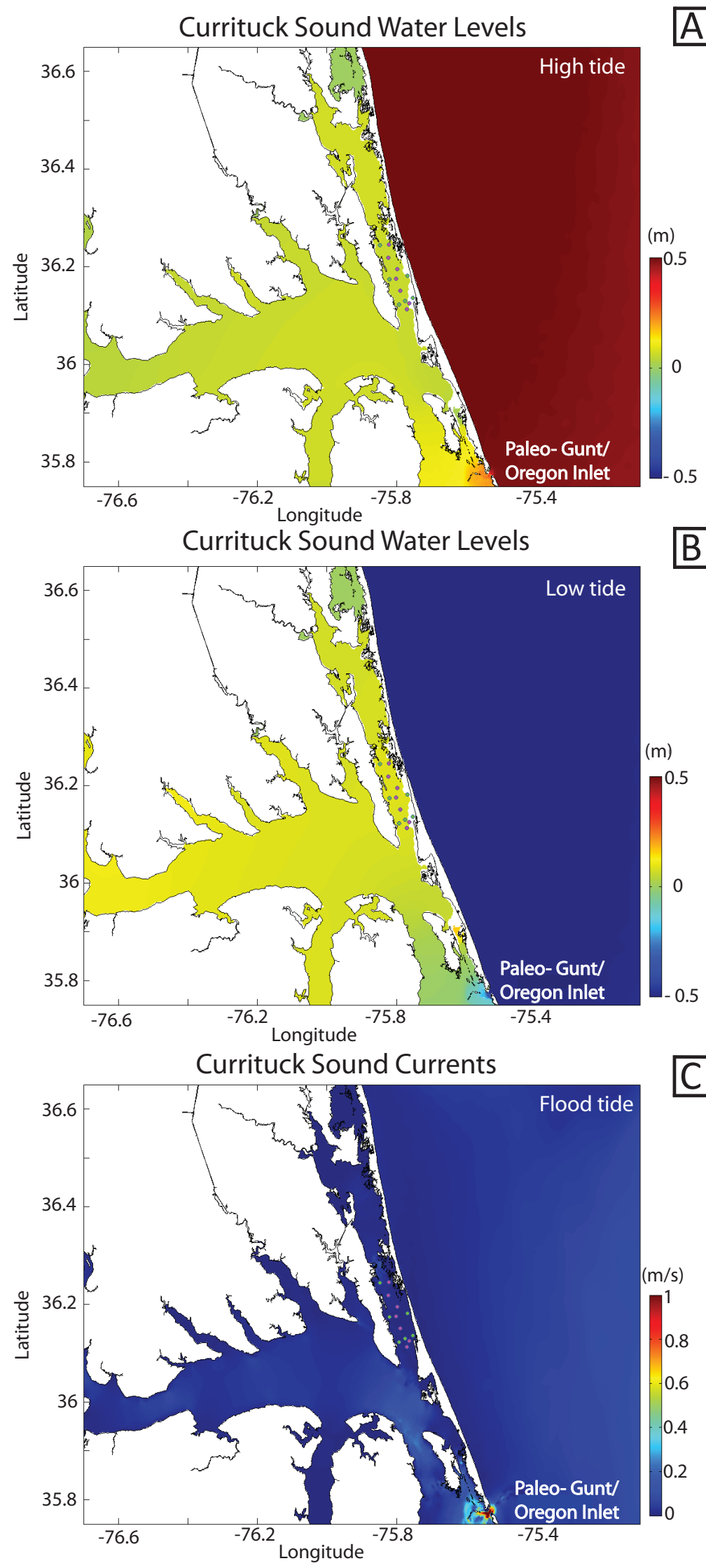

Figure 13: $<500$ cal y BP (modern) Delft3D model run with no inlet open north of Roanoke Island as indicated by Figure 9D. A and B) Currituck and Albemarle sounds largely maintain their respective water levels during this time slice while the water level in Pamlico Sound near Gunt/Oregon Inlet has a range of $0.1 \mathrm{~m}$. C) Water current magnitude, with a maximum velocity of $1 \mathrm{~m} / \mathrm{s}$ directly in the mouth of Gunt/Oregon Inlet and very little velocity found elsewhere throughout the system 
The Delft3D models (Figure 13) show that interactions with Oregon Inlet both before and after the $19^{\text {th }}$ century loss of Roanoke marshes and the formation of Croatan Sound, had, and still has, little to no impact on Currituck Sound.

\section{e. 1590 A.D. (White-deBry Map)}

Historical data provide a snap-shot in time from 1590 A.D. when the first European map of the area was created (White-deBry map, Figure 14). The map indicates that there were five inlets open in 1590. Delft3D models (Figure 15) suggest that this configuration of inlets results in areas of tidal range up to ca. $40 \mathrm{~cm}$. This snap-shot, however, displays the most widely felt current velocities ranging from 0.3 to $0.7 \mathrm{~m} / \mathrm{s}$ in Currituck Sound.

The models described above suggest that, while tidal influence in southern Currituck Sound did occur, influence was limited to very localized areas. The models also show that there is a lag associated with the tides (i.e., they are hyposynchronous), which creates the currents found in the inlets. Current measurements were derived from the model at each core location for each time interval; these data were then compared to core logs. Some of these comparisons indicate a close correlation between current velocity and sediment characteristics - see vibracore VC8 (Figure 16A). However, not all current velocity plots match well with core logs as shown by vibracore VC2 (Figure 16B). This may be because the modeled inlets are too large, or wrongly located, thereby creating modeled currents stronger or weaker than actually existed at any point in time. 


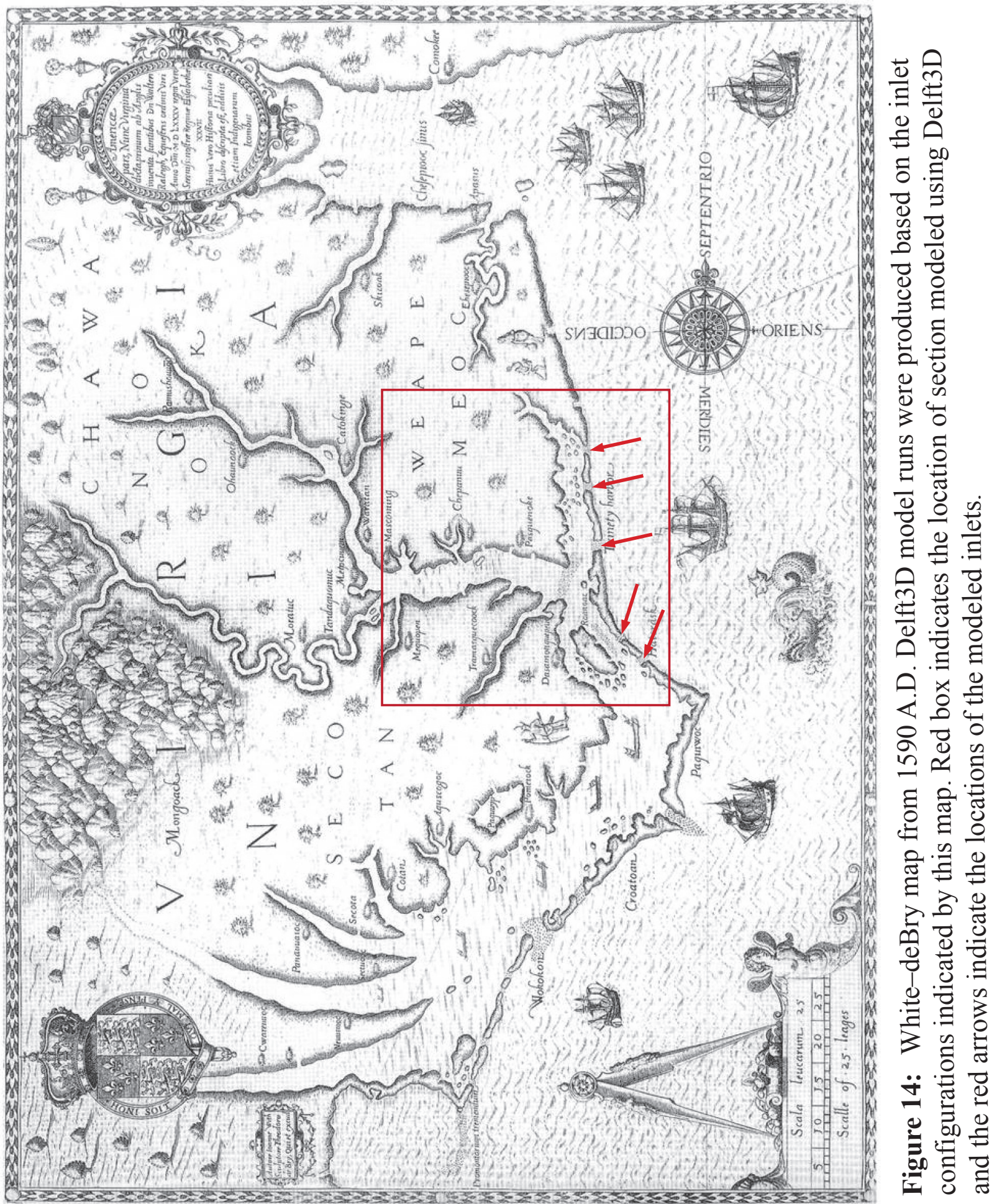



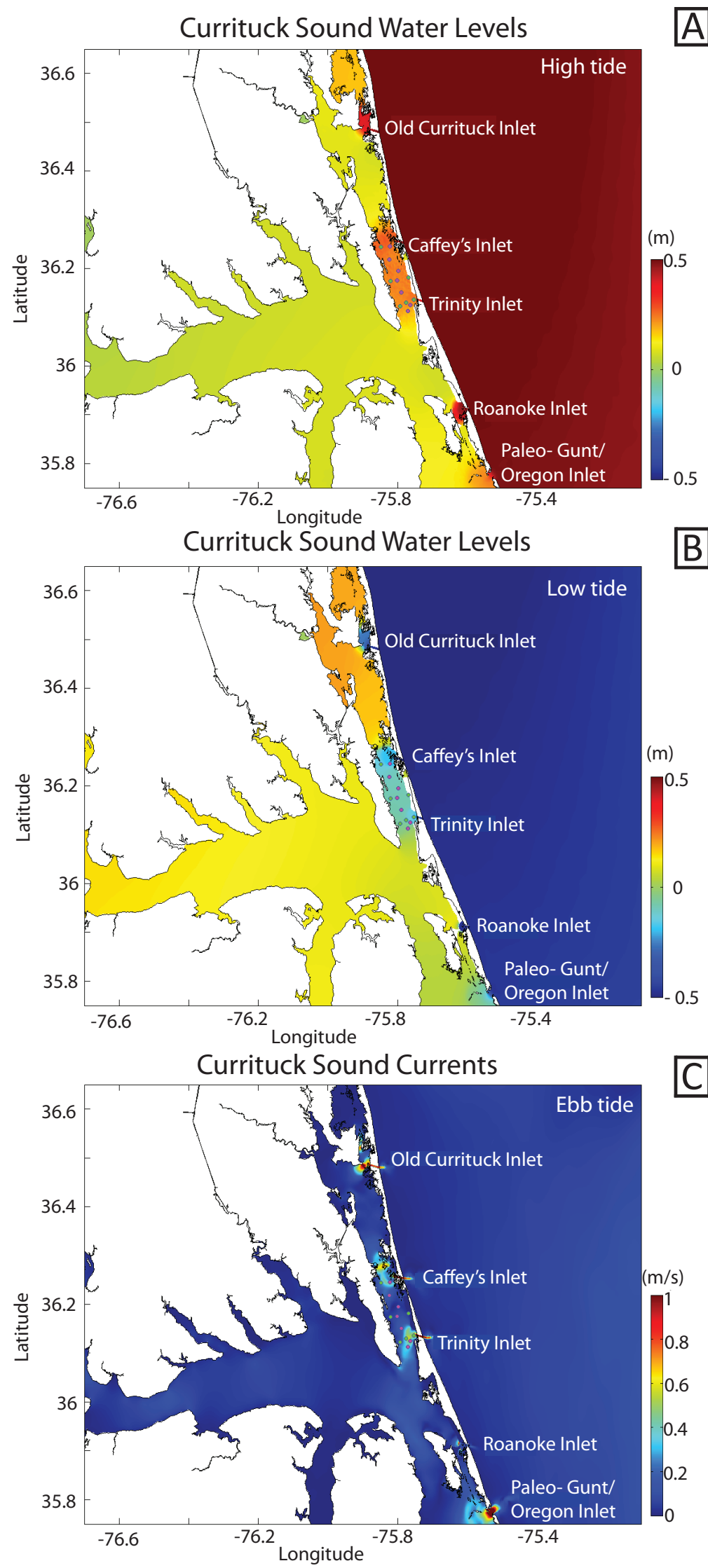

Figure 15: 1590 A.D. Delft3D model run with Old Currituck, Caffey's, Trinity, Roanoke and paleo- Gunt/Oregon inlets open as indicated by the White-de Bry map (Figure 14). A) High tide in the ocean $(0.5 \mathrm{~m})$ and its effects on the estuarine system. A maximum of $0.25 \mathrm{~m}$ water level change is felt within Currituck Sound and water level changes of up to $0.5 \mathrm{~m}$ are felt close to the inlets in northern Currituck Sound and south of Roanoke Island. B) Low tide in the ocean $(-0.5 \mathrm{~m})$ and its effects on the estuarine system.

Southern Currituck Sound experiences water level of -0.25 $\mathrm{m}$ while northern Currituck Sound and Albemarle Sound experience water levels of 0.15 m. C) Water current magnitude, with a maximum velocity of 1 $\mathrm{m} / \mathrm{s}$ directly in the inlet mouths and velocities ranging from 0.3 to $0.7 \mathrm{~m} / \mathrm{s}$ felt locally in Currituck Sound. This inlet configuration creates the largest magnitude and most widespread tidal impacts of all modeled scenarios. 


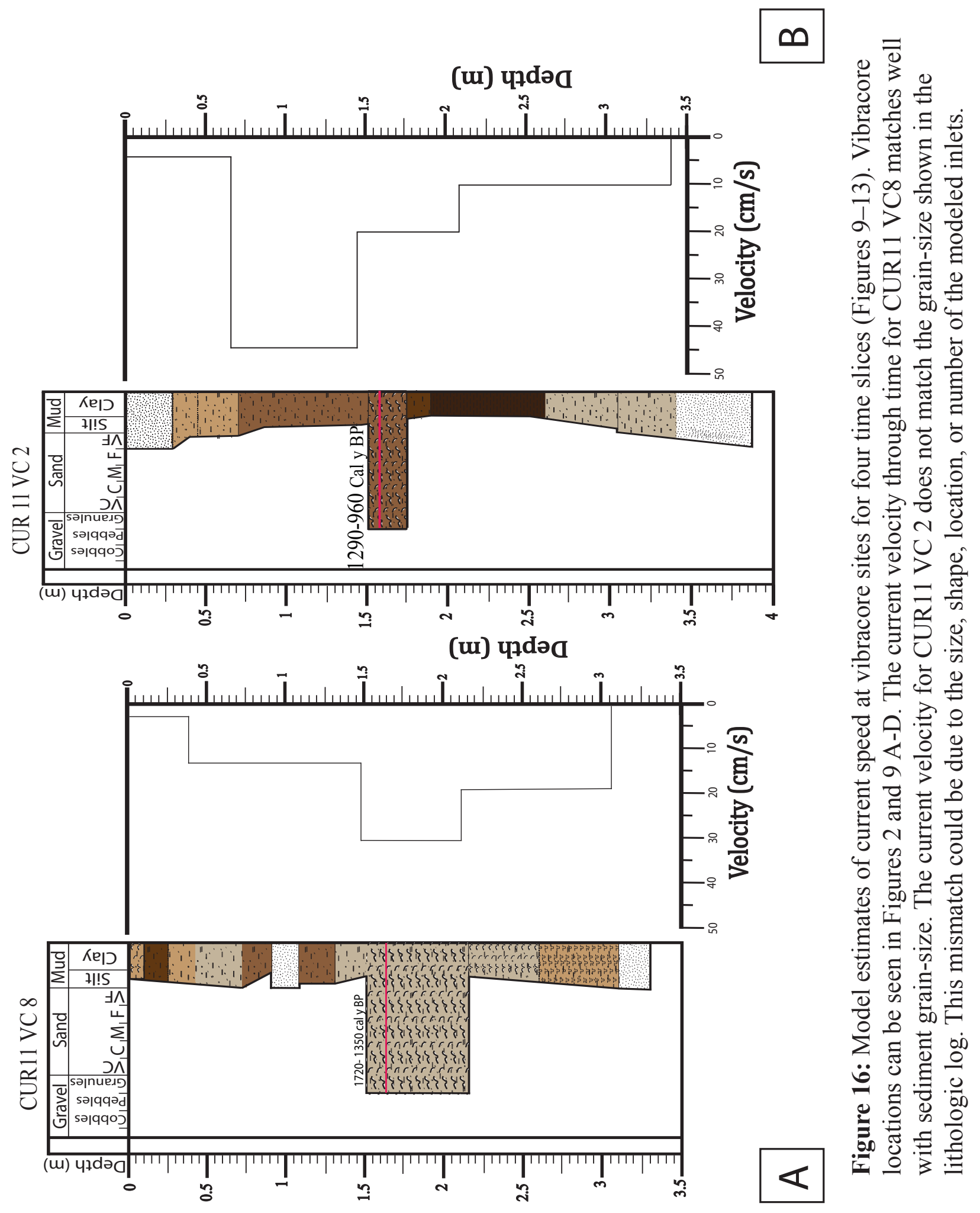




\section{Comparison to Other Studies}

Data from this investigation may be used to confirm or modify existing models of barrier island and estuarine evolution in response to sea-level rise. For example, Oertel et al. (1992) provides a landscape topography model of estuarine evolution in response to the flooding of antecedent topography. As sea-level rise transgresses over the landscape initially, the rivers flood and become the bay area while the higher areas become marshes and tidal flats. As the system progresses the bay becomes larger and the barrier islands are perched upon the interfluves with inlets in the locations of paleoriver valleys. The model appears to be relevant for Currituck Sound, North Carolina in that it invokes strong antecedent controls on the stratigraphy and morphology of the modern lagoon. However, there are no paleoriver valleys through which stable inlets are located in Currituck Sound, as there are further south from my study area.

The Dalrymple et al. (1992) model of the evolution of drowned river-valley estuaries is a well-referenced model. However, it does not apply to Currituck Sound, as there are no large drowned river-valley in the subsurface and the morphology of the Sound, and thus the relative influence of wave and tidal processes, is a function of the barrier island morphology, as opposed to river valley orientation.

Stolper et al. (2005) produced a morphological-behaviour model specifically of the Currituck Sound study area that attempts to demonstrate the evolution of the barrier islands and Currituck Sound in response to sea-level rise. Their study used the GEOMBEST model of shoreface, barrier, and estuarine migration, which includes sediment supply, shelf slope and erodibility, and sea-level rise rates as inputs. The study produced three models based on variations in barrier volume, and the erodibility of the 
underlying Pleistocene unit. All three models suggest that Currituck Sound should contain a stacked record of estuarine sediments of varying thickness which underlie the barrier islands.

The findings of Stolper et al. (2005), although informative, do not agree well with the geological evolution of Currituck Sound as recognized in this study. Differences may be accounted for largely by the Stolper et al. assumptions that barrier volume and width remained constant during transgression, and that transgression along the Currituck coastline was continuous. It is clear that neither of these assumptions were satisfied along the Currituck coast. Data indicate that the initial rapid transgression, which likely produced a low volume barrier and eroded the Pleistocene substrate (producing $\mathrm{H}_{\mathrm{MRS}}$ ), was followed by regression, producing a very high volume barrier, then a final phase of transgression. These data suggest that modifications to the GEOMBEST model, that include appropriate barrier island morphological changes based upon geological reconstructions, coupled with a hydrodynamic model, may improve modeling results.

The presence of the open marine embayment at the eastern end of Albemarle Sound at ca. 5000-3000 cal y BP, as proposed in Culver et al. (2008), was not discounted by the modeling results. It appears possible, based on model reconstructions, that the open embayment could have occurred with little impact on current velocities and tides within Currituck Sound. 


\section{Summary}

1) This study reconstructs the late Holocene ( 5000 cal y BP to present) evolution of Currituck Sound using geophysical, sedimentological, and micropaleontological data. These data were then used, in cooperation with Delft3D hydrpdynamic modeling, to understand the hydrodynamic and paleoenvironmental changes that occurred in response to barrier island morphologic change and sea level rise.

2) Geophysical data display reflections that define a complex system of marine, bay and tidal ravinement beginning around $4500 \mathrm{cal}$ y BP.

3) The litho- and biofacies interpretations indicate a transition from fresh water to high brackish (with inlets) and then to low brackish (few to no inlets) over time.

4) The paleoenvironmental reconstruction and modeling for $\sim 5000-3000$ cal y BP show that Currituck Sound was largely isolated from marine influence, despite Albemarle Inlet being open, with one small inlet open in the southern end of the Sound. Currituck Sound was predominantly a freshwater lagoon with a hardwood swamp perched on a paleotopographic high in the northern end of the study area and a shallow subtidal sand shoal at the eastern edge of the Sound.

5) Paleoenvironmental reconstructions for $\sim 3000-1000$ cal y BP indicate that a large number of inlets were open at this time allowing for exchange with marine waters and the presence of extensive oyster bioherms in the center and eastern edge of Currituck Sound. The western edge of the sound was characterized by fresh to low brackish conditions. There was still a hardwood swamp at the northern end of the study area and a shallow subtidal shoal in the eastern side of the Sound. 
6) Paleoenvironmental reconstructions for $\sim 1000-500$ cal y BP indicate two inlets at this time, one in the northern end of the study area, near historic Caffey's Inlet, and one in the southern end, near historic Trinity Inlet. In the vicinity of historic Caffey's Inlet there was a gradational change from high salinity and oysters in the center of the Sound to mid- brackish to low brackish environments away from the inlet. The presence of an inlet near historic Trinity Inlet is indicated by high salinity foraminifera and oysters. The majority of the Sound was low salinity brackish at this time.

7) Paleoenvironmental reconstructions for $<500$ cal y BP (modern) together with modeling indicate, in low resolution, that southern Currituck Sound has had midto low salinities throughout the past 500 years with a general trend to lower salinity conditions over time. This reflects the historically documented closures of many inlets in the Outer Banks; there is currently no hydraulic connection to marine waters in Currituck Sound. The entire Sound is a low brackish lagoon with differences in sedimentology influenced by the presence of former inlets.

8) The Delft3D models show that the impacts of open inlets in Currituck Sound are largely localized. In general, the models agree with the geological data. However, some model data mismatches the geologic data, this could be due to the size, shape, location, or number of the modeled inlets. 


\section{Works Cited}

Abbene, I.J., S.J., Corbett, D.R., Buzas, M.A., and Tully, L.S., 2006. Distribution of foraminifera in Pamlico Sound, North Carolina, over the past century: Journal of Foraminiferal Research, v. 36, p. 135-151.

Applin, E.R., Ellisor, A.E., and Kniker, H.T., 1925. Subsurface stratigraphy of the coastal plain of Texas and Louisiana: Bulletin of the American Association of Petroleum Geologists, v. 9, p. 79-122.

Blott, S.J., and Pye, K., 2001. Gradistat: grain size distribution and statistics package for the analysis of unconsolidated sediments: Earth Surface Processes and Landforms, v. 26, p. 1237-1248.

Boothroyd, J.C., Friedrich, N.E., and McGinn, S.R., 1985. Geology of microtidal coastal lagoons: Rhode Island: Marine Geology, v. 63, p. 35-76.

Boss, S.K., Hoffman, C.W., and Cooper, B., 2002. Influence of fluvial prcesses on the Quaternary geologic framework of the continental shelf, North Carolina, USA: Marine Geology, v. 183, p. 45-65.

Brady, G.S., and Robinson, G., 1870. The Ostracoda and Foraminifera of tidal rivers, with an analysis and descriptions of the foraminifera by H.B. Brady; Part II: Annals and Magazine of Natural History, series 4, v. 6, p. 273-306.

Cole, W.S., 1931. The Pliocene and Pleistocene foraminifera of Florida: Florida State Geological Survey Bulletin, v. 6, 77 p.

Cronin T.M., Dwyer, G.S., Kamiya, T., Schwede, S., and Willard, D.A., 2003. Medieval Warm Period, Little Ice Age and $20^{\text {th }}$ century temperature variability from Chesapeake Bay: Global and Planetary Change, v. 36, p. 17-29. 
Culver, S.J., and Buzas, M.A., 1980. Distribution of recent benthic foraminifera off the North American Atlantic coast: Smithsonian Contributions to the Marine Sciences, v. 13, p. 1-512.

Culver, S.J., Woo, H.J., Oertel, G.E., and Buzas, M.A., 1996. Foraminifera of coastal depositional environments, Virginia, USA: distribution and taphonomy: Palaios, v. 11, p. $459-486$.

Culver, S.J., and Horton, B.P., 2005. Infaunal marsh foraminifera from the outer banks, North Carolina, USA: Journal of Foraminiferal Research, v. 35, 148-170.

Culver, S.J., Ames, D.V., Corbett, D.R., Mallinson, D.J., Riggs, S.R., Smith, C.G., and Vance, D.J., 2006. Foraminiferal and sedimentary record of late Holocene barrier island evolution, Pea Island, North Carolina: the role of storm overwash, inlet processes, and anthropogenic modification: Journal of Coastal Research, v. 22, p. 836-846.

Culver, S. J., Grand Pre, C. A., Mallinson, D. J., Riggs, S. R., Corbett, D. R., Foley, J., Hale, M., Metger, L., Ricardo, J., Rosenberger, J., Smith, C. G., Smith, C. W., Snyder S. W., and Twamley, D., 2007. Late Holocene barrier island collapse: Outer Banks, North Carolina, USA: The Sedimentary Record, v. 5, p. 4-8.

Culver, S.J., Farrell, K.M., Mallinson, D.J., Horton, B.P., Willard, D.A., Thieler, E.R., Riggs, S.R., Snyder, S.W., Wehmiller, J.F., Bernhardt, C.E., and Hiller, C., 2008. Micropaleontologic recond of late Pliocene and Quaternary paleoenvironments in the northern Albemarle Embayment, North Carolina, USA: Palaeogeography, Palaeoclimatology, Palaeoecology, v. 264, p. 54-77.

Cumming, W.P., 1958. The Southeast in Early Maps. North Carolina Press, 284 p. 
Cushman, J.A, and Brönnimann, P., 1948. Some new genera and species of foraminifera from brackish water of Trinidad: Contributions from the Cushman Laboratory for Foraminiferal Research, v. 24, p. 15-21.

Dalrymple, R.W., Zaitlin, B.A., and Boyd, R., 1992. Estuarine facies models: conceptual basis and stratigraphic implications: Journal of Sedimentary Petrology, v. 62, p. $1130-1146$.

Davis, R.A., Cuffe, C.K., Kowalski, K.A., and Shock, E.J., 2003. Stratigraphic models for microtidal tidal deltas; examples from the Florida Gulf coast: Marine Geology, v. 200 , p. $49-60$.

Delft Hydraulics, 2006. Delft3D- FLOW user manual. Tech. Rep. Version 3.13.

Ehrenberg, C.G., 1840. Eine weitere Erlauterung des Organismus mehrerer in Berlin lebend beobachteter Polythalamien der Nordsee. Koenigliche Preuss Akadaemie de Wissenschaften: Berlin, p. 18-23.

Ehrenberg, C.G., 1841. Uber noch jetzt zahlreich lebende Thierarten der Kreidebildung und den Organismus der Polythalamien: Koenigliche Preuss Akadaemie der Wissenschaften, Physik-Math, Il., Abhandl., Jahrg., p. 81-174.

Elias, E.P.L., Cleveringa, J., Buijsman, M.C., Roelvink. J.A., and Stive, M.J.F., 2006. Field and model data analysis of sand transport patterns in Texel tidal inlet (The Netherlands): Coastal Engineering, v. 53, p. 505-529.

Fisher, J.J., 1962. Geomorphic Expression of Former Inlets Along the Outer Banks of North Carolina: Master's Thesis, University of North Carolina, Chapel Hill, NC, $120 \mathrm{p}$. 
Folk, R.L., 1974. Petrology of Sedimentary Rocks. Hemphill Publishing Company. Austin, Texas, $182 \mathrm{p}$.

Fritz, H.M., Blount, C., Sokoloski, R., Singleton, J., Fuggle, A., McAdoo, B.G., Moore, A., Grass, C., and Tate, B., 2007. Hurricane Katrina storm surge distribution and field observations on the Mississippi Barrier Islands: Estuarine, Coastal and Shelf Science, v. 74, p. 12-20.

Grand Pre, C. A., Culver, S. J., Mallinson, D. J., Farrell, K. M., Corbett, D. R., Horton, B.P., Hillier, C., Riggs, S. R., Snyder, S. W., and Buzas, M. A., 2011. Rapid Holocene coastal change revealed by high-resolution micropaleontological analysis, Pamlico Sound, North Carolina, USA: Quaternary Research, v. 76, p. 319-334.

Grossman, S., and Benson, R.H., 1967. Ecology of Rhizopodea and Ostracoda of southern Pamlico Sound region, North Carolina: The University of Kansas Paleontological Contributions, v. 44, p. 1-90.

Hippensteel, S.P., and Martin, R.E., 1999. Foraminifera as an indicator of overwash deposits, barrier island sediment supply, and barrier island evolution: Folly Island, South Carolina: Palaeogeography, Palaeoclimatology, Palaeoecology, v. 149, p. $115-125$.

Horton, B.P., Peltier, W.R, Culver, S.J., Drummond, R., Engelhart, S.E., Kemp, A.C., Mallinson, D., Thieler, E.R., Riggs, S.R., Ames, D.V., and Thomson, K.H., 2009. Holocene sea-level changes along the North Carolina coastline and their implications for glacial isostatic adjustment models: Quaternary Science Reviews, v. 28 , p. 1725-1736. 
Kornfeld, M.M., 1931. Recent littoral Foraminifera from Texas and Louisiana: Contributions from the Department of Geology of Stanford University, v. 1, p. $77-101$.

Köykkä, J., and Lamminen, J., 2011. Tidally influenced clastic epeiric sea at a Mesoproterozoic continental margin, Rjukan Rift Basin, southern Norway: Precambrian Research, v. 185, p. 164-182.

Lentz, S.J., 2001. The influence of stratification on the wind-driven cross-shelf circulation over the North Carolina shelf: Journal of Physical Oceanography, v. 31, p. 2749-2760.

Leorri, E., and Cearreta, A., 2004. Holocene environmental depvelopment of the Bilbao estuary, northern Spain: sequence stratigraphy and foraminiferal interpretation: Marine Micropaleontology, v. 51, p. 75-94.

Leorri, E., Mulligan, R., Mallinson, D., and Cearreta, A., 2011. Sea-level rise and local tidal range changes in coastal embayments: An added complexity in developing reliable sea-level index points: Revista de Gestão Costeira Integrada, v. 11, p. $307-314$.

Lesser, G.R., Roelvink, J.A., van Kester, J.A.T.M., and Stelling, G.S., 2004. Development and validation of a three-dimensional morphological model: Coastal Engineering, v. 51, p. 883-915.

Luettich Jr., R.A., Carr, S.D., Reynolds-Fleming, J.V., Fulcher, C.W., and McNinch, J.E., 2002. Semi-diurnal seiching in a shallow, micro-tidal lagoonal estuary: Continental Shelf Research, v. 22, p. 1669-1681. 
Mallinson, D.J., Riggs, S.R., Thieler, E.R., Culver, S.J., Farrell, K., Foster, D.S., Corbett, D.R., Horton, B.P., and Wehmiller, J.F., 2005. Late Neogene and Quaternary evolution of the northern Albemarle Embayment (mid-Atlantic continental margin, USA): Marine Geology, v. 217, p. 97-117.

Mallinson, D.J., Burdette, K., Mahan, S., and Brook, J., 2008. Optically stimulated luminescence age controls on late Pleistocene and Holocene coastal lithosomes, North Carolina, USA: Quaternary Research, v. 69, p. 97-109.

Mallinson, D.J., Culver, S.J., Riggs, S.R., Thieler, E.R., Foster, D., Wehmiller, J., Farrell, K.M., and Pierson, J., 2010. Regional seismic stratigraphy and controls on the Quaternary evolution of the Cape Hatteras region of the Atlantic passive margin, USA: Marine Geology, v. 268, p. 16-33.

Mallinson, D.J., Smith, C.W., Mahan, S., Culver, S.J., and McDowell, K., 2011. Barrier island response to late Holocene climate events: Quaternary Research, v. 76, p. 46-57.

McBride, R.A., Byrnes, M.R., and Hiland, M.W., 1995. Geomorphic response-type model for barrier coastlines: a regional perspective: Marine Geology, v. 126, p. $143-159$.

Mello, J.F., and Buzas, M.A., 1968. An application of cluster analysis as a method of determining biofacies: Journal of Paleontology, v. 42, p. 747-758.

Montagu, G., 1808. Testacea Britannica, Suppliment. S. Woolmer, Exeter, England, $183 \mathrm{p}$.

Moslow, T.F., and Tye, R.S., 1985. Recognition and characterization of Holocene tidal inlet sequences: Marine Geology, v. 63, p. 129-151. 
Munsterman, D., and Kerstholt, S., 1996. Sodium polytungstate, a new non-toxic alternative to bromoform in heavy liquid separation: Review of Palaeobotony and Palynology, v. 91, p. 417-422.

Natland, M.L., 1938. New species of foraminifera off the west coast of North America and from the later Tertiary of the Los Angeles basin. University of California, Scripps institute of Oceanography Bulletin, v. 4, p. 197-213.

Nichols, M., and Norton, W., 1969. Foraminiferal populations in a coastal plain estuary: Palaeogeography, Palaeoclimatology, Palaeoecology, v. 6, p. 197-213.

Oertel, G.F., Kraft, J.C., Kearney, M.S., and Woo, H.J., 1992. A rational theory for barrier-lagoon development: Quaternary Coasts of the United States: Marine and Lacustrine Systems, SEPM Special Publication 48, p. 77-87.

d'Orbigny, A., 1839. Foraminiferes. In: de la Sagra, R., Histoire Physique, Politique et Naturelle de l'ile de Cuba. A. Bertrand, Paris, 312 p.

Pierce, J.W., 1970. Tidal inlets and washover fans, The Journal of Geology, v.78, p. 230-234.

Riggs, S.R., York, L.L., Wehmiller, J.F., and Snyder, S.W., 1992. Depositional patterns resulting from high frequency Quaternary sea-level fluctuations in northeastern North Carolina: Quaternary Coasts of the United States: Marine and Lacustrine Systems: SEPM Special Publications no. 48, p. 141-153.

Riggs, S. R., Cleary, W. J., and Snyder, S. W., 1995. Influence of inherited geologic framework on barrier shoreface morphology and dynamics: Marine Geology, v. 126, p. 213-234. 
Ritchie, W., and Penland, S., 1998. Rapid dune chages associated with overwash processes on the deltaic coast of South Louisiana: Marine Geology, v. 81, p. $97-122$.

Robinson, M.M., and McBride, R.A., 2003. Old Currituck Inlet, Virginia/North Carolina: inlet history documented by foraminiferal evidence, (PartII), Coastal Sediments '03: American Society of Civil Engineers Press, Reston, VA, 14 p.

Robinson, M.M., and McBride, R.A., 2006. Benthic foraminifera from a relict flood tidal delta along the Virginia/North Carolina Outer Banks: Micropaleontology, v. 52, p. $67-80$.

Robinson, M.M., and McBride, R.A., 2008. Anatomy of a shoreface sand ridge revisited using foraminifera: False Cape Shoals, Virginia/North Carolina inner shelf: Continental Shelf Research, v. 28, p. 2428-2441.

Schnitker, D., 1971. Distribution of foraminifera on the North Carolina continental shelf: Tulane Studies in Geology and Paleontology, v. 8, p. 169-215.

Scott, D.B., 1976. Brackish-water foraminifera from southern California and description of Polysaccammina ipohalina n. gen., n. sp.: Journal of Foraminiferal Research, v. 6 p. $312-321$.

Smith, C.G., Culver, S.J., Mallinson, D.J., Riggs, S.R., and Corbett, D.R., 2009. Using foraminifera to recognize former flood-tide deltas in the Holocene stratigraphic record: examples from the Outer Banks, North Carolina: Stratigraphy, v. 6, p. $67-78$.

Stick, D., 1958. The Outer Banks of North Carolina 1584-1958. Chapel Hill: The University of North Carolina Press, 367 p. 
Stolper, D., List, J.H., and Thieler, E.R., 2005. Simulating the evolution of coastal morphology and stratigraphy with a new morphological-behaviour model (GEOMBEST): Marine Geology, v. 218, p. 17-36.

Stuiver, M., and Reimer, P.J., 1993. Extended ${ }^{14} \mathrm{C}$ data base and revised CALIB $3.0{ }^{14} \mathrm{C}$ age calibration program: Radiocarbon, v. 35, p. 215-230.

Stuiver, M., Reimer, P. J., and Braziunas, T. F., 1998. High-precision radiocarbon age calibration for terrestrial and marine samples: Radiocarbon, v. 40, p. 1127-1151.

Terquem, O., 1875. Essai sur le classement des animaux qui vivent sur la plage et dans les environs de Dunquerque: Paris, Frac. 1, p. 1-54.

USACE (US Army Corps of Engineers) 2010. Currituck Sound, North Carolina Ecosystem Restoration Feasibility Study. Feasibility Scoping Meeting Report February 2010.

Vance, D.J., Culver, S.J., Corbett, D.R., and Buzas, M.A., 2006. Foraminifera in the Albemarle estuarine system, North Carolina: distribution and recent environmental change: Journal of Foraminiferal Research, v. 36, p. 15-33.

Warren, A.D, 1957. Foraminifera of the Buras-Scofield Bayou region, southeast Louisiana: Contributions from the Cushman Foundation for Foraminiferal Research, v. 8, p. 29-40.

Williamson, W.C., 1858. On the Recent Foraminifera of Great Britain: Ray Society, $107 \mathrm{p}$.

Woo, H. J., Culver, S.J., and Oertel, G.F, 1997. Benthic foraminiferal communities of a barrier-lagoon system, Virginia, USA Journal of Coastal Research, v. 13, p. $1192-1200$. 


\section{Appendix 1: Foraminiferal species Reference list}

Original references to the taxa identified to the species level.

Ammobaculites crassus Warren, 1957, p. 32, pl. 3, figs. 5-7.

Ammonia parkinsoniana (d'Orbigny) = Rosalina parkinsoniana d'Orbigny, 1839, p. 99, pl. 4, figs. 25-27.

Ammotium salsum (Cushman and Brönnimann) = Ammobaculites salsus Cushman and Brönnimann, 1948, p. 16, pl. 3, figs. 7-9.

Deuterammina ochracea $($ Williamson $)=$ Rotalina ochracea Williamson, 1858, p. 55, pl. 4, fig. 112.

Elphidium excavatum $($ Terquem $)=$ Polystomella excavata Terquem, 1875, p. 20, pl. 2, figs. $2 \mathrm{a}, \mathrm{b}$.

Elphidium galvestonense Kornfeld = Elphidium gunteri Cole var. galvestonensis

Kornfeld, 1931, p. 87, pl. 15, fig. 1.

Elphidium gunteri Cole, 1931, p. 34, pl. 4, figs. 9, 10.

Elphidium transluscens Natland, 1938, p. 144, pl. 5, figs. 3, 4.

Haynesina germanica (Ehrenberg): Nonionina germanica Ehrenberg, 1840, pl. 23;

Ehrenberg, 1841, pl. 2, figs. $1 \mathrm{a}-\mathrm{g}$.

Hanzawaia strattoni (Applin) $=$ Truncatulina americana (Cushman) var. strattoni Applin and others, 1925, p. 99, pl. 3, fig. 8.

Jadammina macrescens $($ Brady) $=$ Trochammina inflata $($ Montagu) var. macrescens

Brady, in Brady and Robertson, 1870, p. 47, pl. 11, figs. 5a-c.

Miliammina fusca (Brady) = Quinqueloculina fusca Brady, in Brady and Robertson, 1870, p. 47, pl. 11, figs. 2, 3.

Polysaccammina ipohalina Scott, 1976, p. 316, pl. 2, figs. 1-4.

Trochammina inflata (Montagu): Nautilus inflatus Montagu, 1808, p. 81, pl. 18, fig. 3. 
II. Appendix: Foraminiferal Plates

\section{Plate 1}

\section{Figures}

1. Elphidium transluscens (Natland)

2. Haynesina germanica (Ehrenberg)

3. Elphidium gunteri (Cole)

4. Elphidium galvestonense (Kornfeld)

5, 6. Ammonia parkinsoniana (d'Orbigny); spiral and umbilical views

7. Ammotium salsum (Cushman and Brönnimann)

8. Elphidium excavatum (Terquem)

9. Ammobaculites crassus (Warren) 


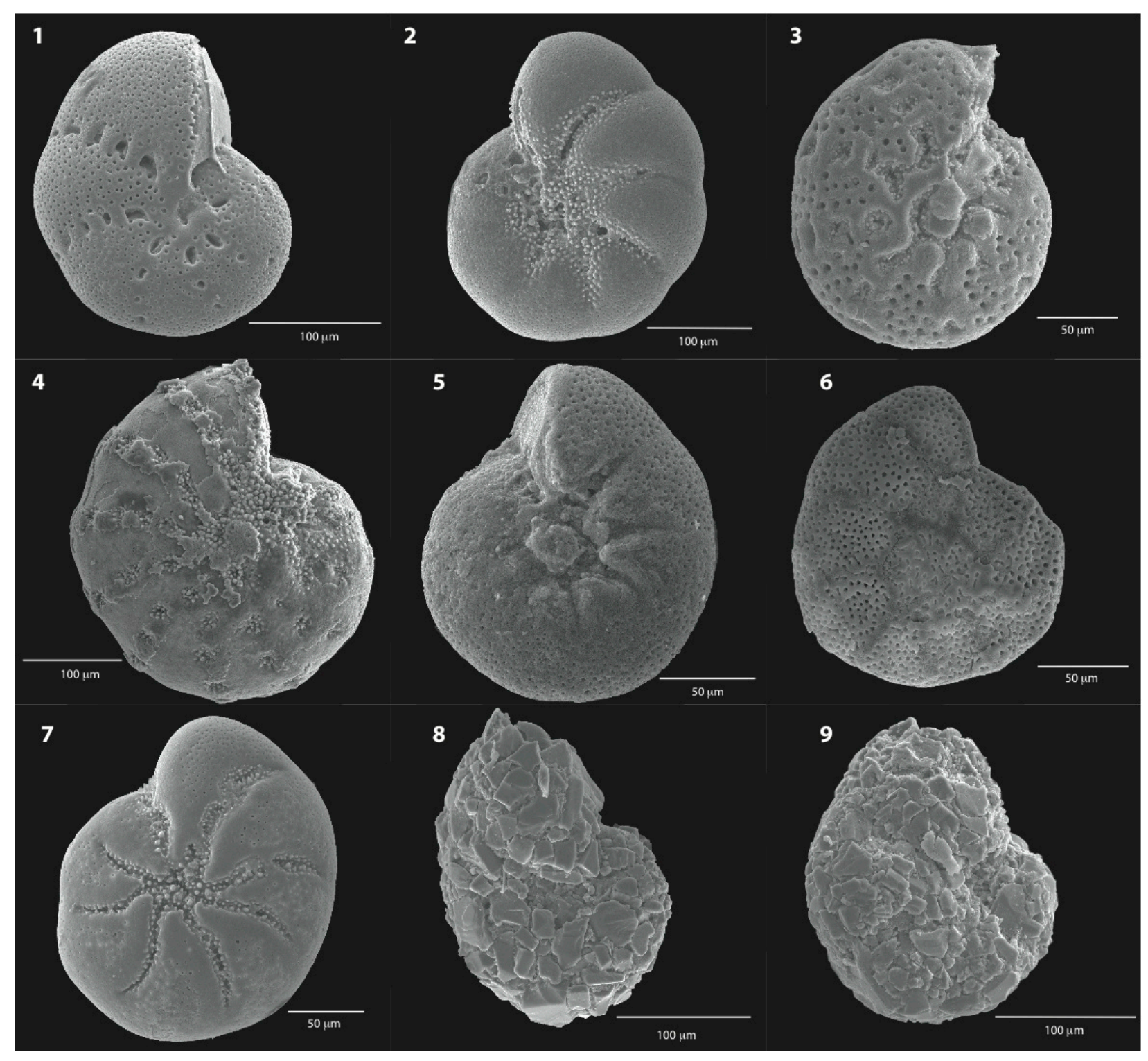




\section{Plate 2}

\section{Figures}

1. Ammonia parkinsoniana (d'Orbigny); umbilical view

2. Ammonia parkinsoniana (d'Orbigny); spiral view

3. Ammonia parkinsoniana (d'Orbigny); apertural view

4. Organic lining of Ammonia parkinsoniana (d'Orbigny); oblique umbilical view

5. Organic lining of Ammonia parkinsoniana (d'Orbigny); spiral view

6. Organic lining of Ammonia parkinsoniana (d'Orbigny); oblique apertural view

7. Genus A sp. A (organic): umbilical view

8. Genus A sp. A (organic): spiral view

9. Genus A sp. A (organic): apertural view

10. Genus A sp. A (organic): aperturall view

11. Genus A sp. A (organic): apertural view 


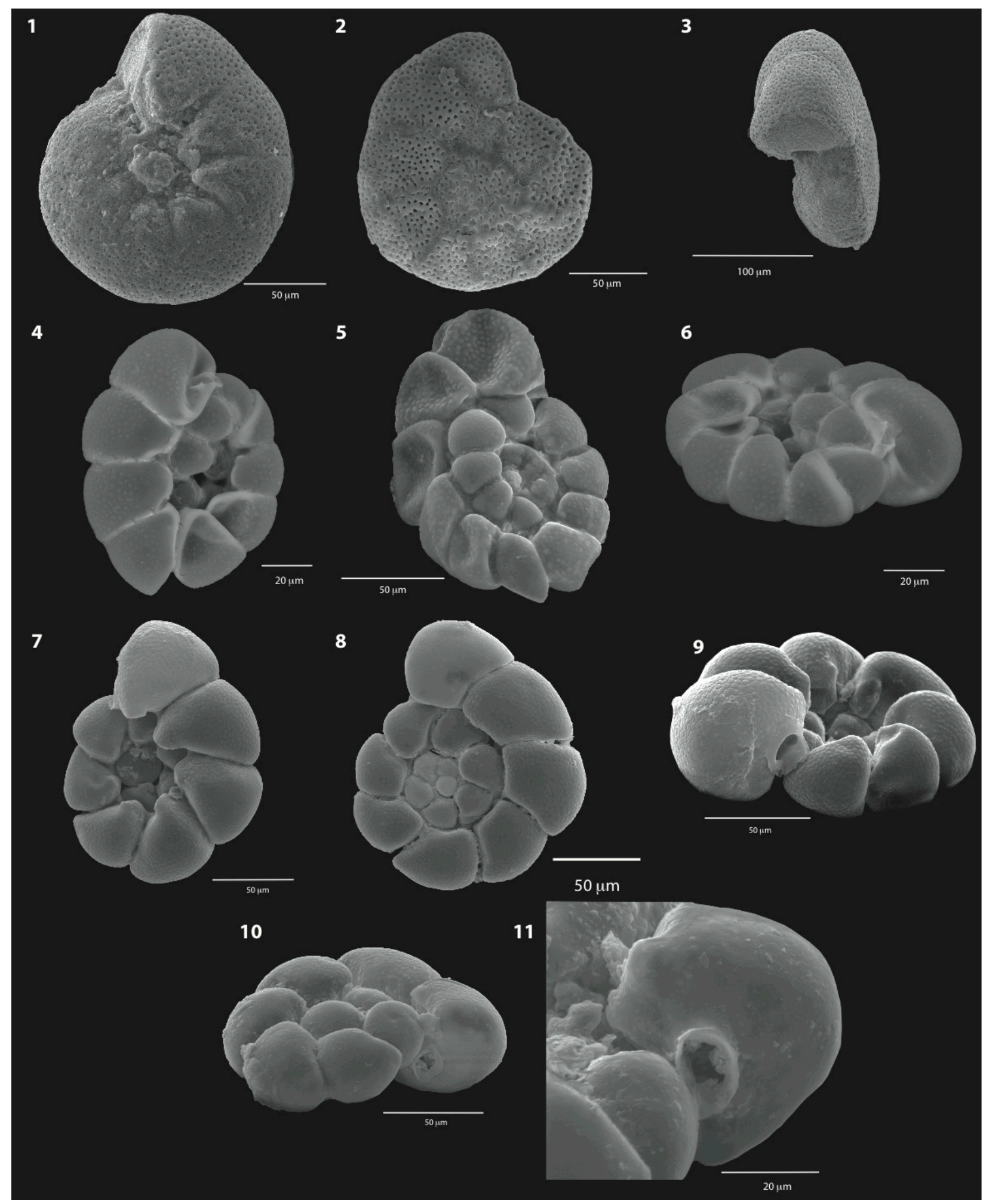




\section{Appendix: Vibracore locations}

\begin{tabular}{|c|c|c|c|c|}
\hline Core Name & Lat & Long & Water depth $(\mathrm{m})$ & Core length $(\mathrm{m})$ \\
\hline CUR11 VC1 & 36.244 & -75.847 & 1.8 & 1.93 \\
\hline CUR11 VC2 & 36.245 & -75.821 & 1.2 & 3.88 \\
\hline CUR11 VC3 & 36.218 & -75.823 & 2.39 & 2.95 \\
\hline CUR11 VC4 & 36.195 & -75.797 & 2.28 & 3.66 \\
\hline CUR11 VC5 & 36.174 & -75.820 & 2.28 & 3.85 \\
\hline CUR11 VC6 & 36.175 & -75.801 & 2.13 & 6.10 \\
\hline CUR11 VC7 & 36.181 & -75.769 & 2.13 & 2.10 \\
\hline CUR11 VC8 & 36.151 & -75.789 & 2.89 & 3.30 \\
\hline CUR11 VC9 & 36.136 & -75.752 & 2.74 & 2.30 \\
\hline CUR11 VC10 & 36.122 & -75.792 & 2.44 & 3.26 \\
\hline CUR11 VC11 & 36.129 & -75.774 & 2.13 & 3.90 \\
\hline CUR11 VC 12 & 36.125 & -75.763 & 2.44 & 3.22 \\
\hline CUR11 VC13 & 36.112 & -75.770 & 2.44 & 2.43 \\
\hline
\end{tabular}




\section{Appendix: Vibracore Logs}

In the following 13 vibracore logs the blue lines represent optically stimulated

luminescence age estimates. The red lines are radiocarbon age estimates. The symbols to the right of the cores represent the different foraminiferal biofacies at the depth the sample was taken from. 


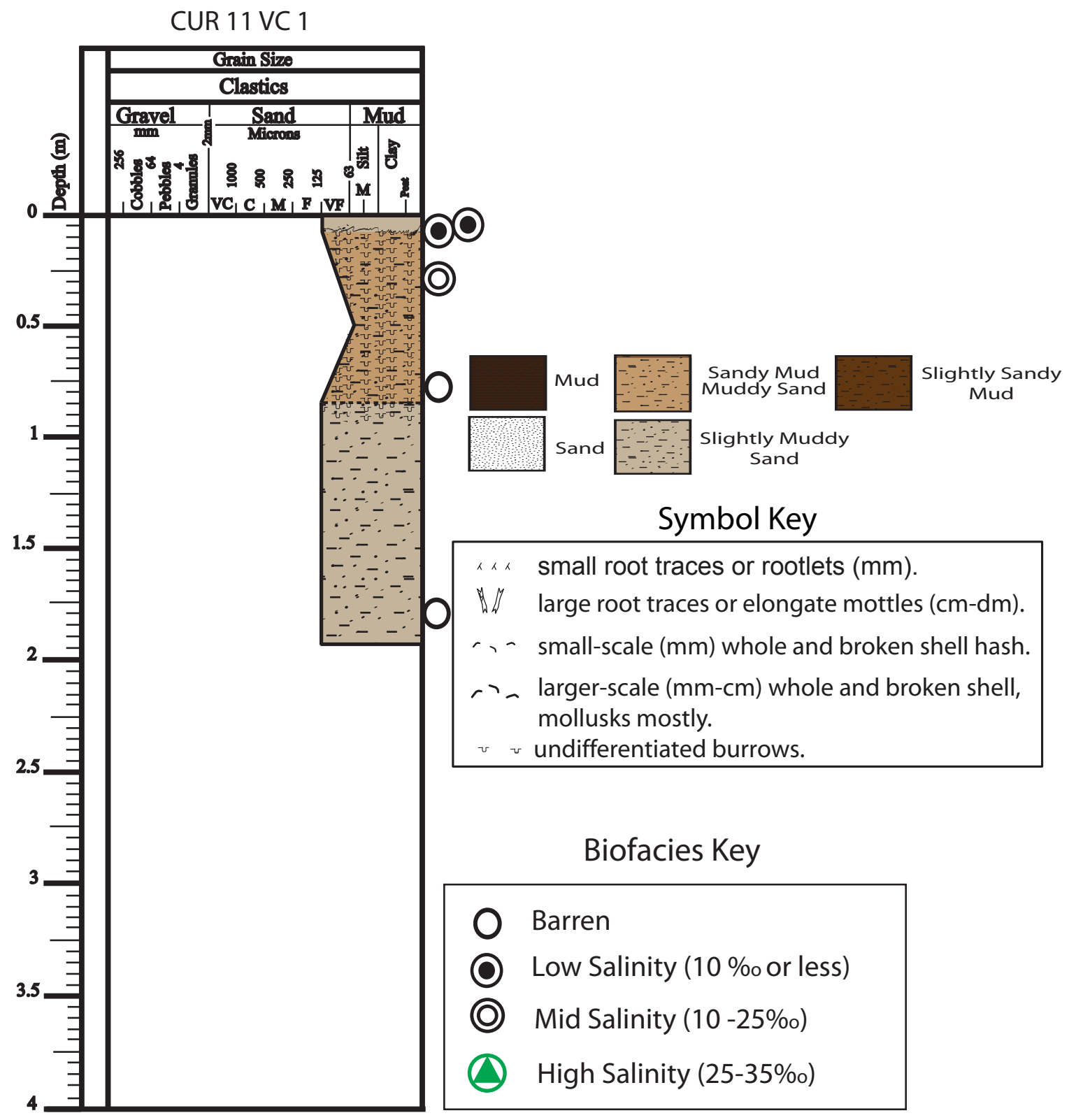




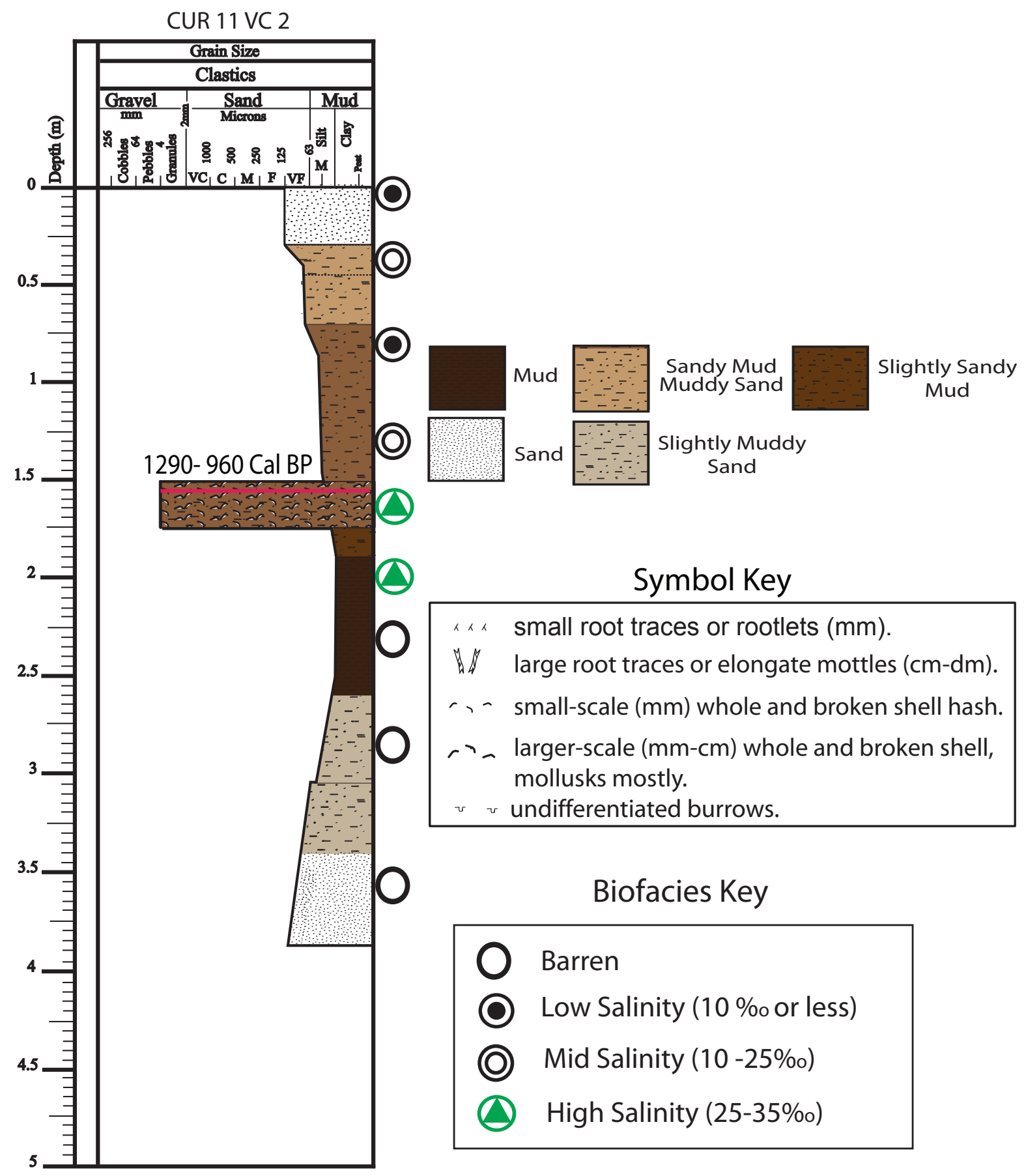




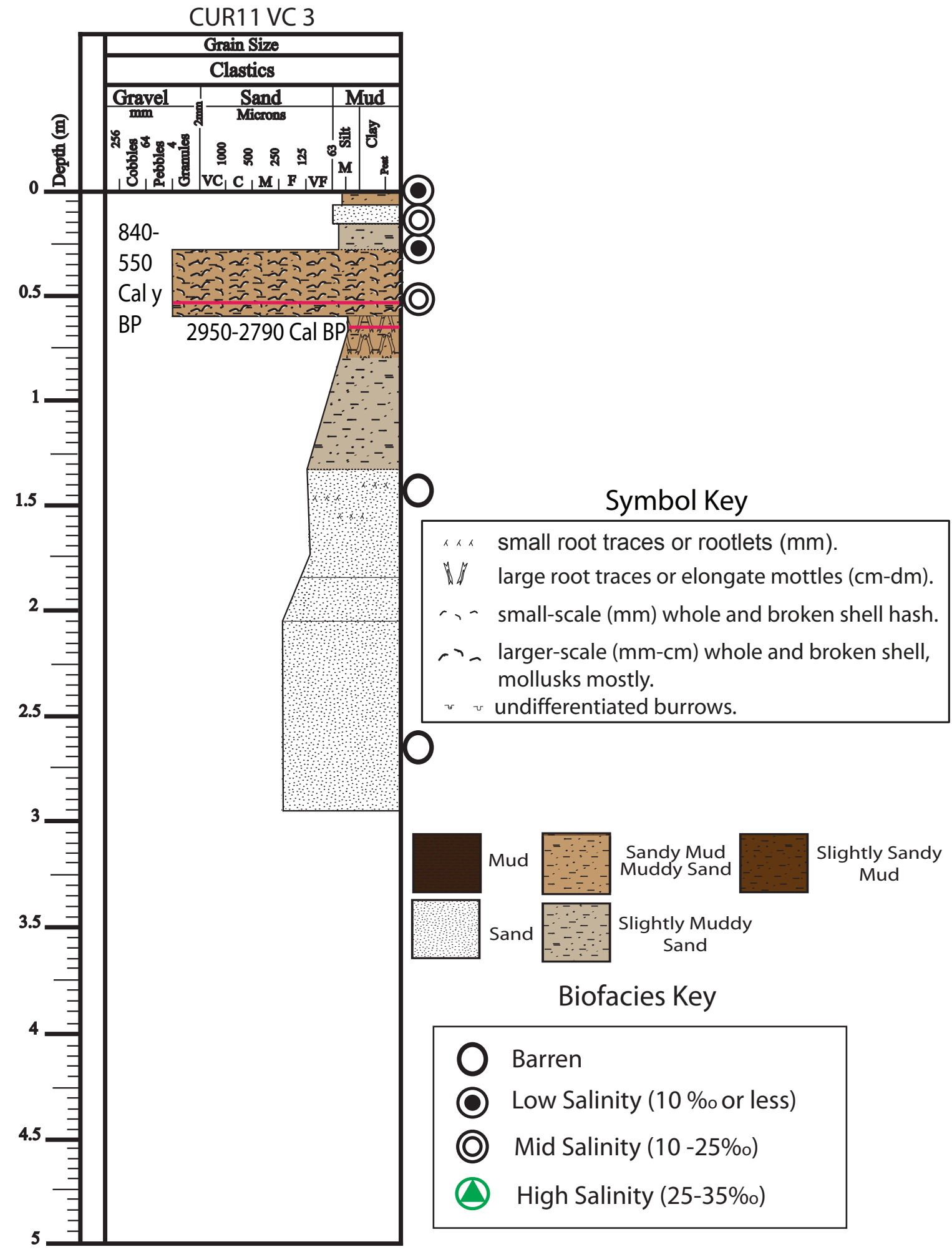




\section{CUR11 VC 4}

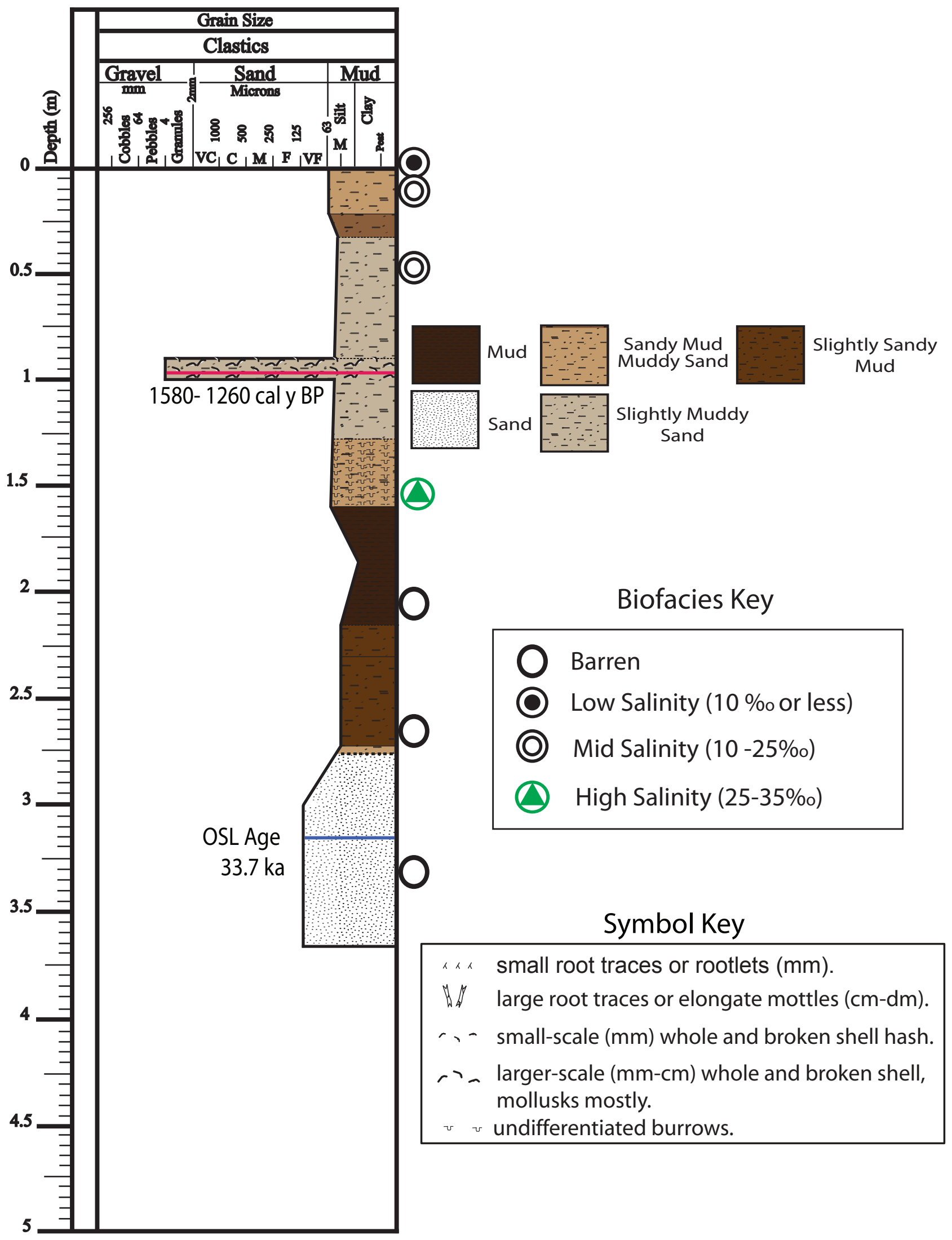




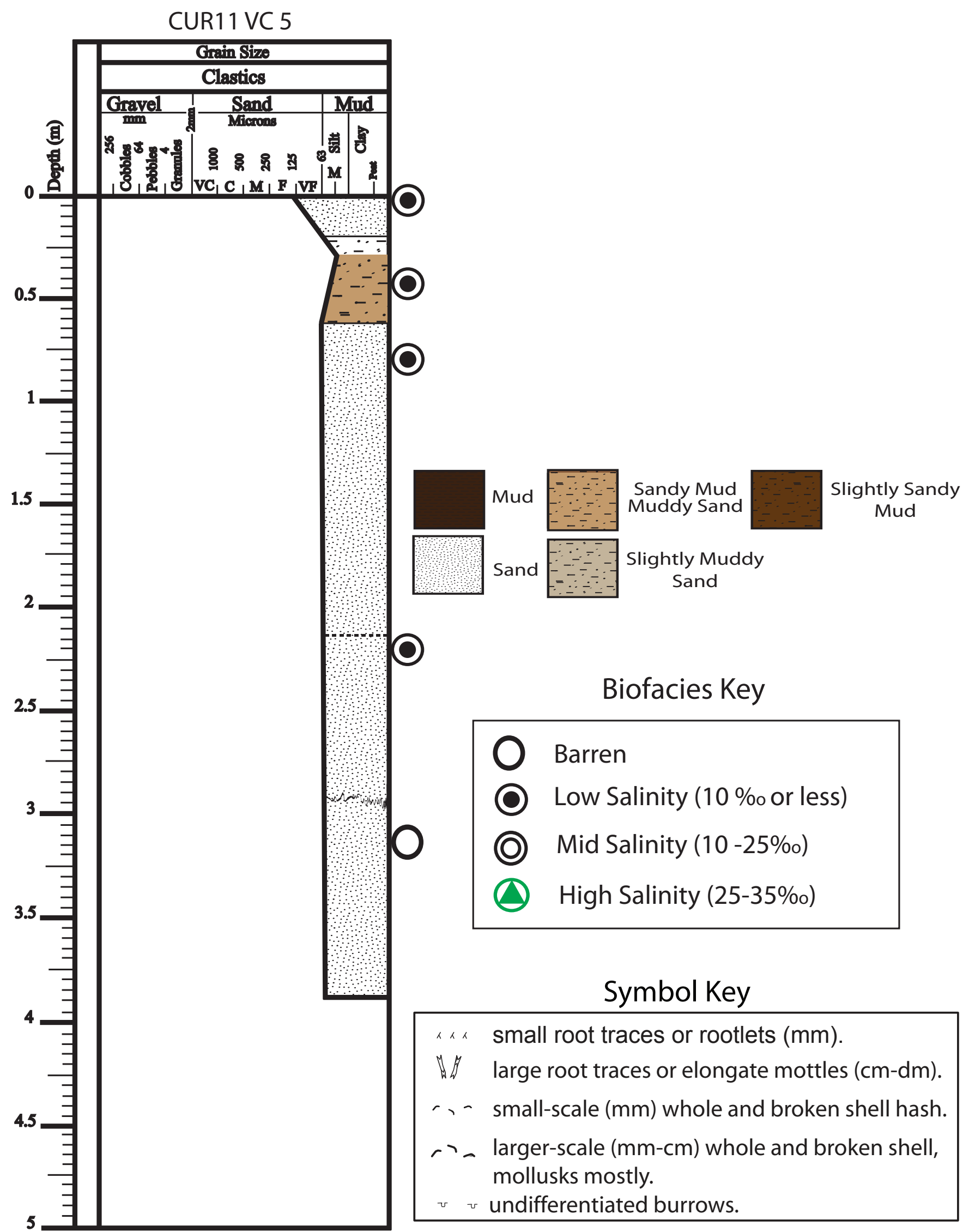




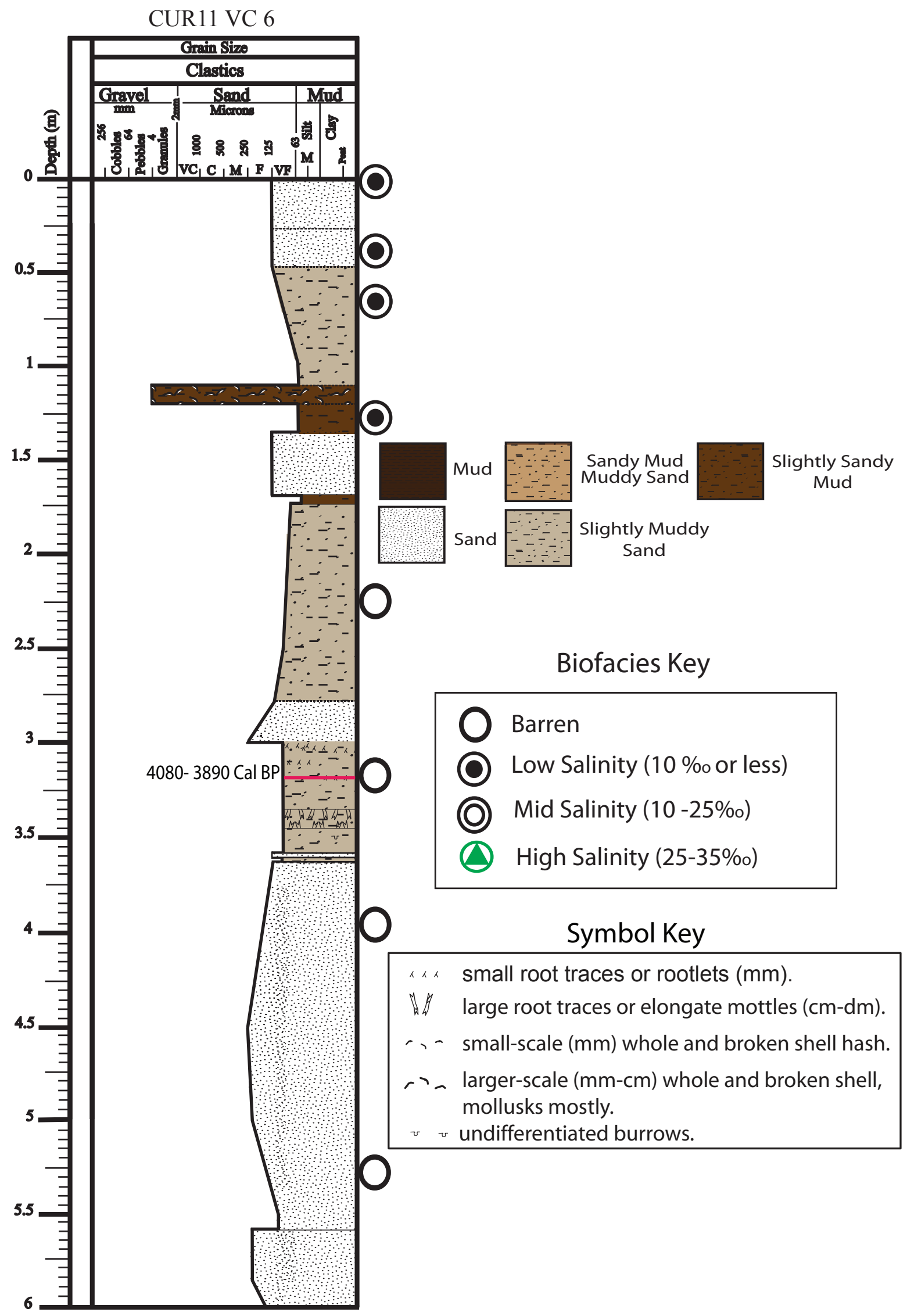




\section{CUR11 VC 7}

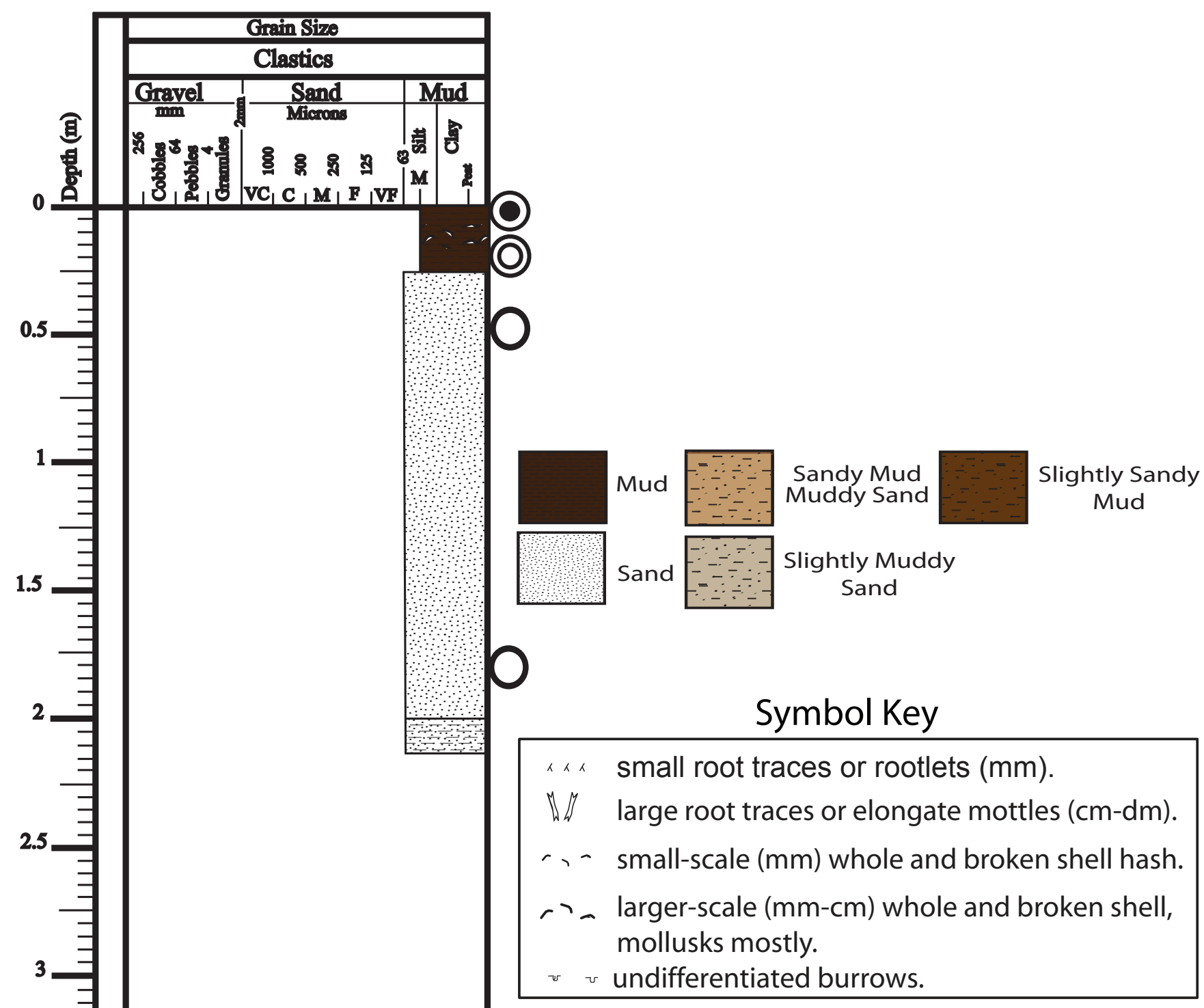

\section{Biofacies Key}

Barren

(2) Low Salinity (10\%o or less)

(a) Mid Salinity (10-25\%)

(a) High Salinity (25-35\%o) 


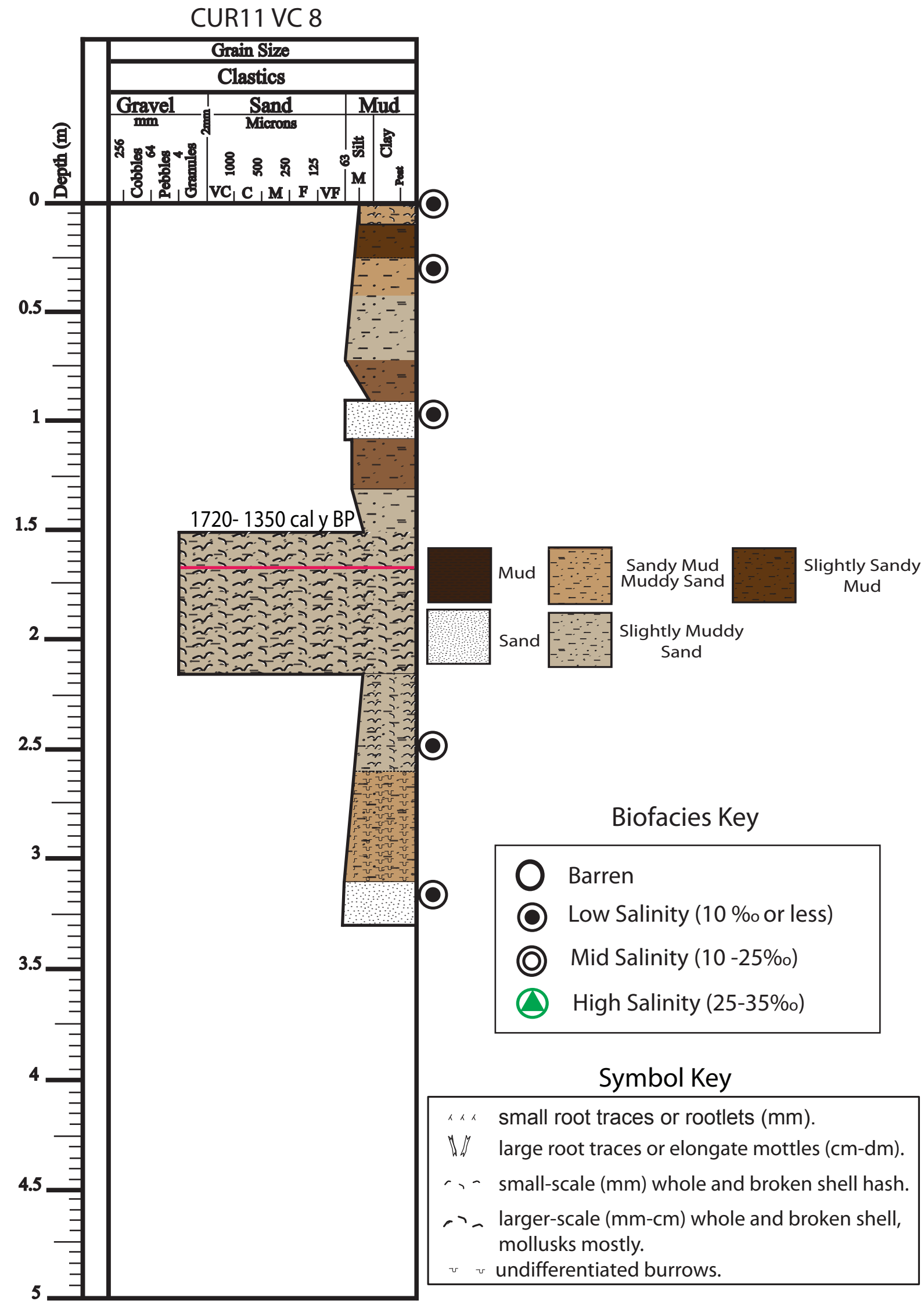




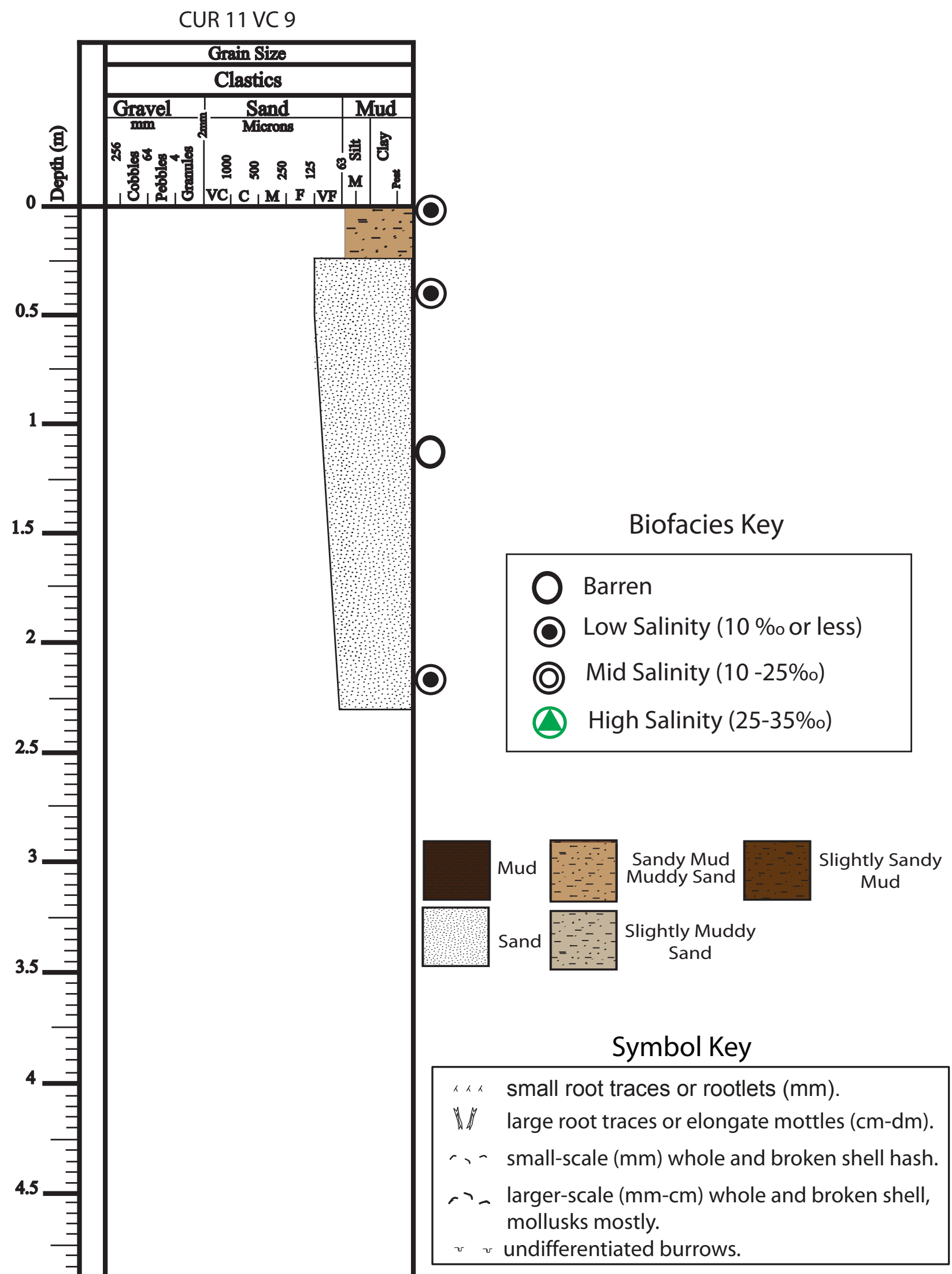


CUR 11 VC 10

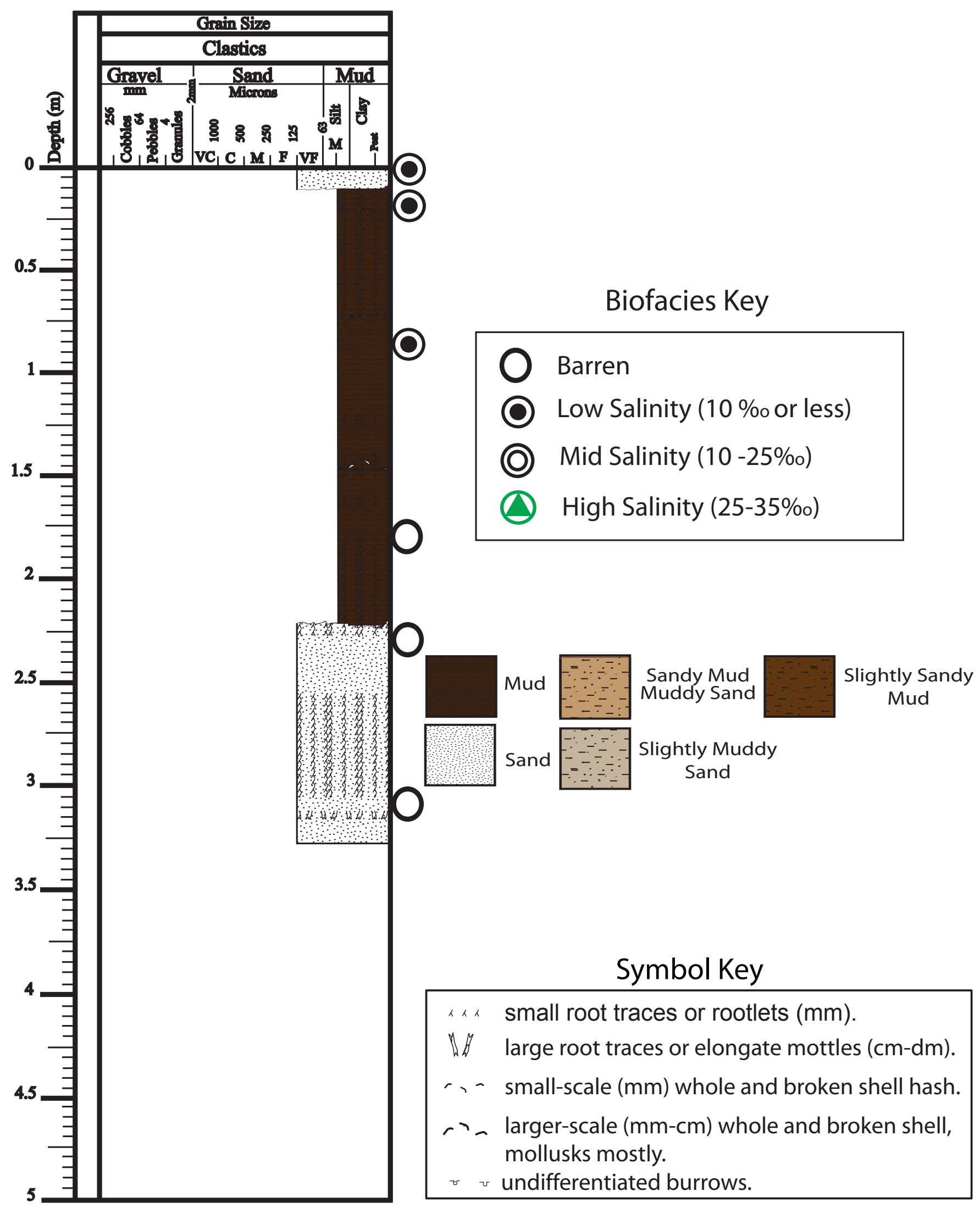




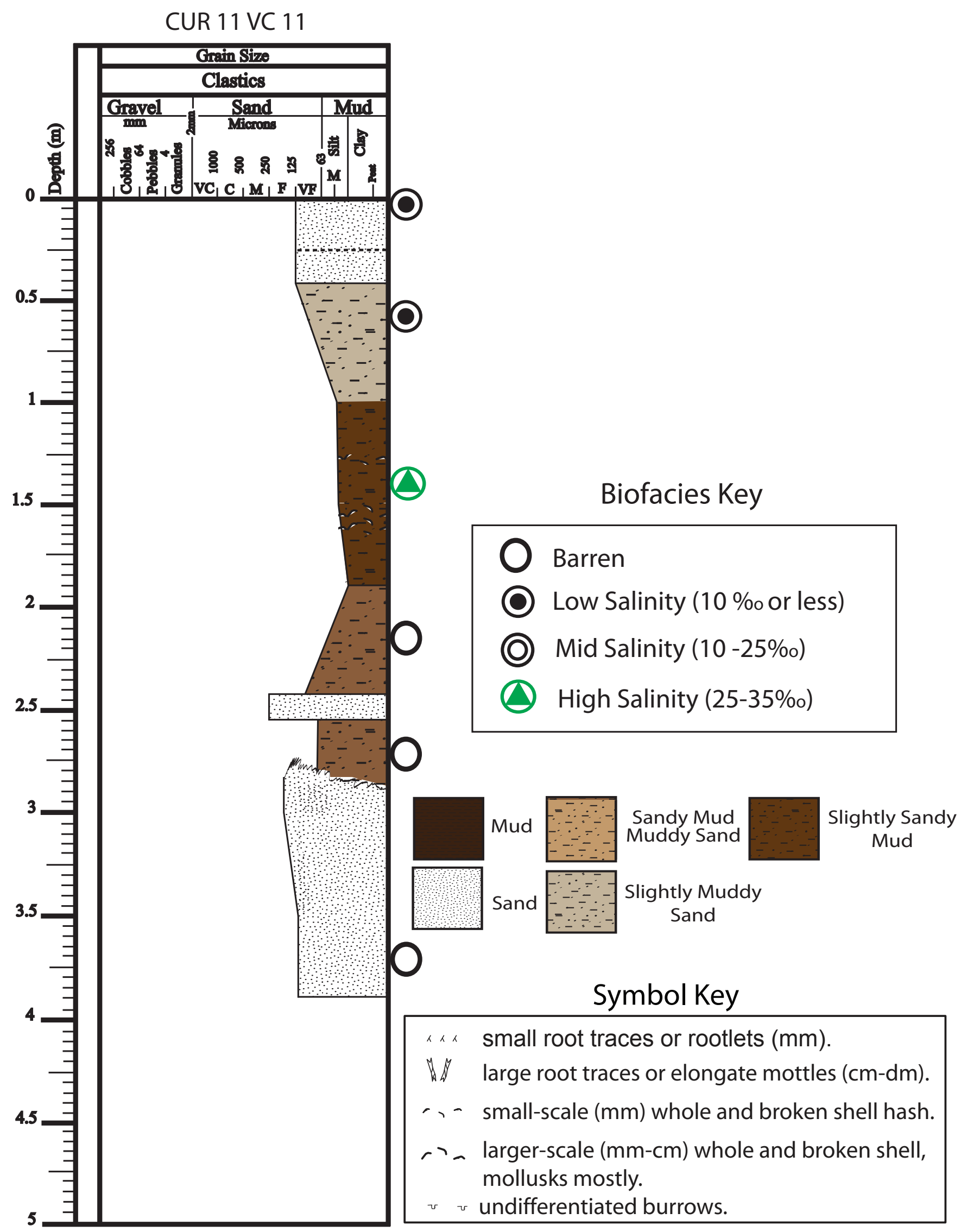




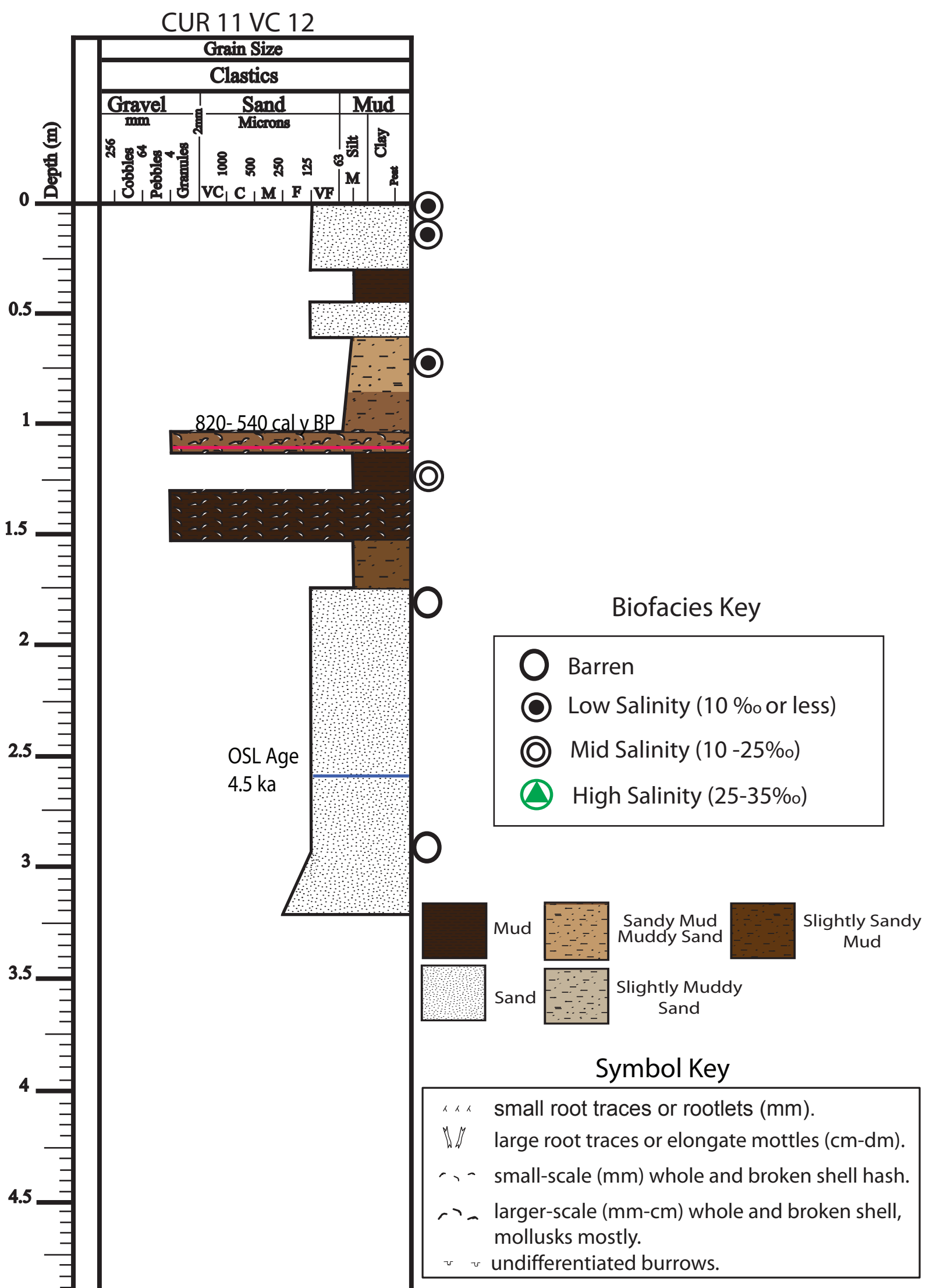




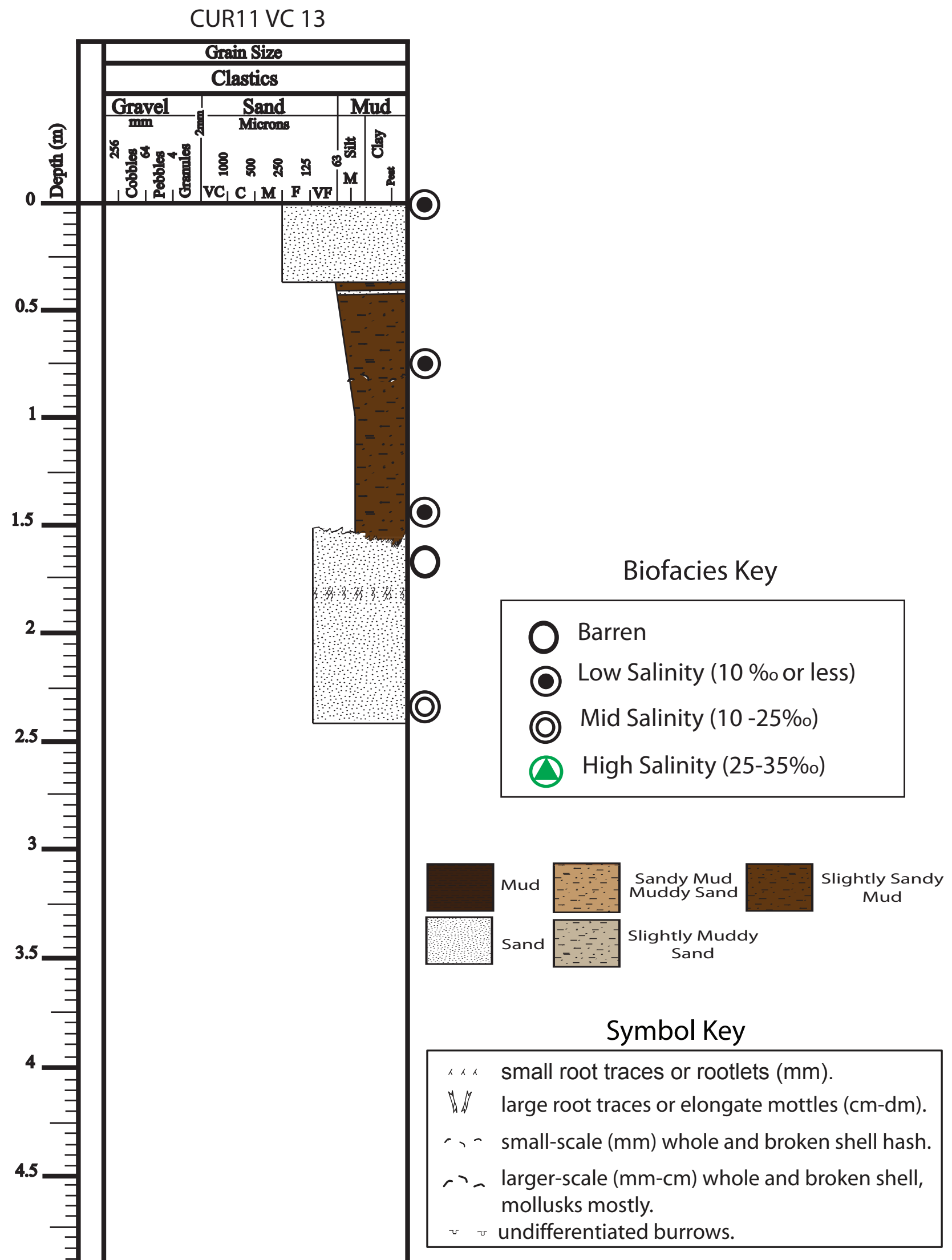




\section{Appendix: Grain-size Data}

\begin{tabular}{|c|c|c|c|c|c|}
\hline Sample Name & $\begin{array}{l}\mathrm{cm} \text { below } \\
\text { core top }\end{array}$ & Sorting & Skewness & Mean & Mediar \\
\hline \multicolumn{6}{|l|}{ CUR11 VC1 } \\
\hline GS 77-79 & 77 & 0.799 & -0.342 & 1.951 & 2.077 \\
\hline \multicolumn{6}{|l|}{ CUR11 VC1 } \\
\hline GS 184-186 & 184 & 0.488 & -0.014 & 2.174 & 2.178 \\
\hline \multicolumn{6}{|l|}{ CUR11 VC2 } \\
\hline GS 39-41 & 39 & 0.999 & 0.285 & 2.702 & 2.680 \\
\hline \multicolumn{6}{|l|}{ CUR11 VC2 } \\
\hline GS 354-356 & 354 & 0.570 & -0.186 & 2.403 & 2.465 \\
\hline \multicolumn{6}{|l|}{ CUR11 VC3 } \\
\hline GS 11-13 & 11 & 0.460 & -0.116 & 2.591 & 2.634 \\
\hline \multicolumn{6}{|l|}{ CUR11 VC3 } \\
\hline GS 89-91 & 89 & 0.690 & -0.300 & 2.225 & 2.275 \\
\hline \multicolumn{6}{|l|}{ CUR11 VC3 } \\
\hline GS 258-260 & 258 & 0.418 & -0.009 & 2.541 & 2.555 \\
\hline \multicolumn{6}{|l|}{ CUR11 VC4 } \\
\hline GS 260-262 & 260 & 0.563 & 0.050 & 2.366 & 2.344 \\
\hline \multicolumn{6}{|l|}{ CUR11 VC4 } \\
\hline GS 327-329 & 327 & 0.464 & 0.094 & 2.360 & 2.320 \\
\hline \multicolumn{6}{|l|}{ CUR11 VC5 } \\
\hline GS 80-82 & 80 & 0.415 & -0.072 & 2.437 & 2.428 \\
\hline \multicolumn{6}{|l|}{ CUR11 VC5 } \\
\hline GS 219-221 & 219 & 0.480 & -0.014 & 2.256 & 2.259 \\
\hline \multicolumn{6}{|l|}{ CUR11 VS5 } \\
\hline GS 310-312 & 310 & 0.472 & -0.076 & 2.704 & 2.718 \\
\hline \multicolumn{6}{|l|}{ CUR11 VC6 } \\
\hline GS 226-228 & 226 & 0.939 & -0.145 & 3.080 & 3.138 \\
\hline \multicolumn{6}{|l|}{ CUR11 VC6 } \\
\hline GS 392-394 & 392 & 0.363 & 0.046 & 2.796 & 2.767 \\
\hline \multicolumn{6}{|l|}{ CUR11 VC6 } \\
\hline GS 532-534 & 532 & 0.446 & -0.039 & 2.334 & 2.332 \\
\hline \multicolumn{6}{|l|}{ CUR11 VC7 } \\
\hline GS 47-49 & 47 & 0.376 & 0.048 & 2.841 & 2.806 \\
\hline \multicolumn{6}{|l|}{ CUR11 VC8 } \\
\hline GS 97-99 & 97 & 0.386 & 0.098 & 2.340 & 2.288 \\
\hline CUR11 VC8 & & & & & \\
\hline GS 322-324 & 322 & 0.513 & -0.014 & 2.344 & 2.351 \\
\hline CUR11 VC9 & & & & & \\
\hline GS 39-41 & 39 & 0.546 & -0.214 & 2.558 & 2.615 \\
\hline CUR11 VC9 & & & & & \\
\hline GS 117-119 & 117 & 0.477 & -0.148 & 2.492 & 2.528 \\
\hline CUR11 VC9 & & & & & \\
\hline GS 222-224 & 222 & 0.464 & -0.110 & 2.601 & 2.636 \\
\hline CUR11 VC10 & & & & & \\
\hline GS 225-227 & 225 & 0.642 & -0.259 & 2.424 & 2.532 \\
\hline CUR11 VC10 & & & & & \\
\hline GS 310-312 & 310 & 0.553 & -0.200 & 2.596 & 2.644 \\
\hline CUR11 VC11 & & & & & \\
\hline GS 219-221 & 219 & 0.647 & -0.218 & 2.844 & 2.931 \\
\hline CUR11 VC11 & & & & & \\
\hline GS 376-378 & 376 & 0.427 & 0.103 & 2.468 & 2.433 \\
\hline CUR11 VC12 & & & & & \\
\hline GS 183-185 & 183 & 0.389 & -0.051 & 2.720 & 2.732 \\
\hline CUR11 VC12 & & & & & \\
\hline GS 304-306 & 304 & 0.501 & -0.020 & 1.978 & 1.975 \\
\hline CUR11 VC13 & & & & & \\
\hline GS 159-161 & 159 & 0.406 & -0.164 & 2.539 & 2.582 \\
\hline CUR11 VC13 & & & & & \\
\hline GS 237-239 & 237 & 0.395 & -0.118 & 2.514 & 2.540 \\
\hline
\end{tabular}

Slightly Very Fine Gravelly Fine Sand Well Sorted Fine Sand

Slightly Very Fine Gravelly Very Coarse Silty Fine Sand Moderately Well Sorted Fine Sand Well Sorted Fine Sand

Slightly Very Fine Gravelly Fine Sand Well Sorted Fine Sand

Moderately Well Sorted Fine Sand

Well Sorted Fine Sand

Well Sorted Fine Sand

Well Sorted Fine Sand

Well Sorted Fine Sand

Slightly Very Fine Gravelly Very Fine Sand

Slightly Very Fine Gravelly Fine Sand

Well Sorted Fine Sand

Well Sorted Fine Sand

Slightly Very Fine Gravelly Fine Sand

Moderately Well Sorted Fine Sand

Moderately Well Sorted Fine Sand

Well Sorted Fine Sand

Well Sorted Fine Sand

Slightly Very Fine Gravelly Fine Sand

Slightly Very Fine Gravelly Fine Sand

Moderately Well Sorted Fine Sand

Slightly Very Fine Gravelly Fine Sand

Slightly Very Fine Gravelly Fine Sand

Moderately Well Sorted Medium Sand

Well Sorted Fine Sand

Well Sorted Fine Sand 


\section{Appendix: Percent mud, fine/medium sand and coarse sand/gravel}

\begin{tabular}{|c|c|c|c|c|}
\hline Core & $\begin{array}{l}\text { Depth in core } \\
(\mathrm{cm})\end{array}$ & $\%$ Mud & $\begin{array}{l}\text { \% Sand } \\
(<710 \mu)\end{array}$ & $\begin{array}{c}\% \text { Coarse } \\
\text { Sand/Gravel } \\
(>710 \mu)\end{array}$ \\
\hline CUR11 VC 1 & $2-4$ & 25.05 & 74.37 & 0.58 \\
\hline CUR11 VC 1 & $25-27$ & 28.76 & 71.05 & 0.19 \\
\hline CUR11 VC 1 & $75-77$ & 10.29 & 89.37 & 0.34 \\
\hline CUR11 VC 1 & $182-184$ & 0.87 & 98.99 & 0.14 \\
\hline CUR11 VC 2 & $35-37$ & 15.32 & 84.68 & 0.00 \\
\hline CUR11 VC 2 & $77-79$ & 31.03 & 68.97 & 0.00 \\
\hline CUR11 VC 2 & $138-140$ & 41.22 & 58.77 & 0.01 \\
\hline CUR11 VC 2 & $169-171$ & 31.21 & 59.50 & 9.29 \\
\hline CUR11 VC 2 & $195-197$ & 82.04 & 16.56 & 1.40 \\
\hline CUR11 VC 2 & $232-234$ & 40.03 & 59.90 & 0.07 \\
\hline CUR11 VC 2 & $278-280$ & 40.79 & 58.87 & 0.34 \\
\hline CUR11 VC 2 & $352-354$ & 8.62 & 91.38 & 0.00 \\
\hline CUR11 VC 3 & $9-11$ & 6.52 & 93.48 & 0.00 \\
\hline CUR11 VC 3 & $21-23$ & 31.50 & 68.50 & 0.00 \\
\hline CUR11 VC 3 & $39-41$ & 18.89 & 80.19 & 0.92 \\
\hline CUR11 VC 3 & $87-89$ & 8.92 & 91.07 & 0.01 \\
\hline CUR11 VC 3 & $256-258$ & 5.20 & 94.80 & 0.00 \\
\hline CUR11 VC 4 & $13-15$ & 30.95 & 68.11 & 0.94 \\
\hline CUR11 VC 4 & $47-49$ & 20.55 & 73.72 & 5.74 \\
\hline CUR11 VC 4 & $143-145$ & 28.74 & 71.04 & 0.22 \\
\hline CUR11 VC 4 & $200-202$ & 47.46 & 52.54 & 0.00 \\
\hline CUR11 VC 4 & $258-260$ & 5.68 & 94.25 & 0.07 \\
\hline CUR11 VC 4 & $325-327$ & 5.81 & 94.18 & 0.00 \\
\hline CUR11 VC 5 & $40-42$ & 21.56 & 78.39 & 0.05 \\
\hline CUR11 VC 5 & $78-80$ & 89.99 & 9.55 & 0.47 \\
\hline CUR11 VC 5 & $217-219$ & 6.34 & 93.66 & 0.00 \\
\hline CUR11 VC 5 & $308-310$ & 1.16 & 98.84 & 0.00 \\
\hline CUR11 VC 6 & $38-40$ & 17.12 & 82.13 & 0.74 \\
\hline CUR11 VC 6 & $64-66$ & 37.20 & 62.80 & 0.00 \\
\hline CUR11 VC 6 & $126-128$ & 19.84 & 80.16 & 0.00 \\
\hline CUR11 VC 6 & $224-226$ & 13.56 & 86.44 & 0.00 \\
\hline CUR11 VC 6 & $318-320$ & 15.94 & 83.90 & 0.15 \\
\hline CUR11 VC 6 & $390-392$ & 0.47 & 99.35 & 0.18 \\
\hline CUR11 VC 6 & $530-532$ & 0.87 & 99.13 & 0.00 \\
\hline
\end{tabular}




\begin{tabular}{|c|c|c|c|c|}
\hline Core & $\begin{array}{l}\text { Depth in core } \\
\quad(\mathrm{cm})\end{array}$ & $\%$ Mud & $\begin{array}{l}\text { \% Sand } \\
(<710 \mu)\end{array}$ & $\begin{array}{c}\% \text { Coarse } \\
\text { Sand/Gravel } \\
(>710 \mu)\end{array}$ \\
\hline CUR11 VC 7 & $17-19$ & 30.59 & 68.13 & 1.28 \\
\hline CUR11 VC 7 & $45-47$ & 7.47 & 92.53 & 0.00 \\
\hline CUR11 VC 7 & $180-182$ & 1.81 & 97.55 & 0.65 \\
\hline CUR11 VC 8 & $26-28$ & 34.02 & 65.95 & 0.03 \\
\hline CUR11 VC 8 & $95-97$ & 10.20 & 89.80 & 0.00 \\
\hline CUR11 VC 8 & $167-169$ & 65.85 & 31.91 & 2.24 \\
\hline CUR11 VC 8 & $237-239$ & 68.64 & 31.36 & 0.00 \\
\hline CUR11 VC 8 & $320-322$ & 1.54 & 98.15 & 0.31 \\
\hline CUR11 VC 9 & $37-39$ & 0.30 & 99.30 & 0.40 \\
\hline CUR11 VC 9 & $115-117$ & -0.05 & 98.58 & 1.46 \\
\hline CUR11 VC 9 & $220-222$ & 0.68 & 99.15 & 0.17 \\
\hline CUR11 VC 10 & $18-20$ & 94.96 & 5.04 & 0.00 \\
\hline CUR11 VC 10 & $82-84$ & 98.48 & 0.71 & 0.81 \\
\hline CUR11 VC 10 & $180-182$ & 82.58 & 17.34 & 0.08 \\
\hline CUR11 VC 10 & $223-225$ & 8.40 & 90.27 & 1.32 \\
\hline CUR11 VC 10 & $308-310$ & 4.19 & 95.43 & 0.38 \\
\hline CUR11 VC 11 & $57-59$ & 24.69 & 75.31 & 0.00 \\
\hline CUR11 VC 11 & $138-140$ & 47.45 & 52.09 & 0.46 \\
\hline CUR11 VC 11 & $217-219$ & 10.99 & 88.77 & 0.24 \\
\hline CUR11 VC 11 & $273-275$ & 16.39 & 83.61 & 0.00 \\
\hline CUR11 VC 11 & $374-376$ & 8.58 & 91.42 & 0.00 \\
\hline CUR11 VC 12 & $6-8$ & 47.13 & 52.87 & 0.00 \\
\hline CUR11 VC 12 & $66-68$ & 25.77 & 74.21 & 0.03 \\
\hline CUR11 VC 12 & $123-125$ & 36.56 & 63.23 & 0.21 \\
\hline CUR11 VC 12 & 181-183 & 2.54 & 97.43 & 0.03 \\
\hline CUR11 VC 12 & $302-304$ & 1.98 & 97.47 & 0.55 \\
\hline CUR11 VC 13 & 71-73 & 77.80 & 22.20 & 0.00 \\
\hline CUR11 VC 13 & $138-140$ & 40.26 & 38.20 & 21.54 \\
\hline CUR11 VC 13 & $157-159$ & 0.80 & 99.19 & 0.01 \\
\hline CUR11 VC 13 & $235-237$ & 8.46 & 91.54 & 0.00 \\
\hline
\end{tabular}


